\title{
Product Consistency Testing of West Valley Compositional Variation Glasses
}

\author{
K. M. Olson \\ S. C. Marschman \\ G. F. Piepel \\ G. K. Whiting
}

November 1994

Prepared for the U.S. Department of Energy under Contract DE-AC06-76RLO 1830

Pacific Northwest Laboratory

Richland, Washington 99352 



\section{DISCLAIMER}

This report was prepared as an account of work sponsored by an agency of the United States Government. Neither the United States Government nor any agency thereof, nor any of their employees, make any warranty, express or implied, or assumes any legal liability or responsibility for the accuracy, completeness, or usefulness of any information, apparatus, product, or process disclosed, or represents that its use would not infringe privately owned rights. Reference herein to any specific commercial product, process, or service by trade name, trademark, manufacturer, or otherwise does not necessarily constitute or imply its endorsement, recommendation, or favoring by the United States Government or any agency thereof. The views and opinions of authors expressed herein do not necessarily state or reflect those of the United States Government or any agency thereof. 


\section{DISCLAIMER}

Portions of this document may be illegible in electronic image products. Images are produced from the best available original document. 


\section{Summary}

Nuclear waste glass produced by the West Valley Demonstration Project (WVDP) must meet the requirements of the Waste Acceptance Preliminary Specification (WAPS) as developed by the U.S. Department of Energy (DOE). To assist WVDP in complying with WAPS, the Materials Characterization Center (MCC) at Pacific Northwest Laboratory (PNL) used the Product Consistency Test (PCT) to evaluate 44 West Valley glasses that had previously been tested in FY 1987 and FY 1988. This report summarizes the results of the PCTs.

The glasses tested, which were fabricated as sets of Compositional Variation Glasses for studies performed by the West Valley Support Task (WVST) at PNL during FY 1987 and FY 1988, were doped with Th and $U$ and were variations of West Valley reference glasses. In addition, Approved Reference Material-1 (ARM-1) was used as a test standard (ARM-1 is supplied by the MCC).

The PCT was originated at Westinghouse Savannah River Company (WSRC) by C. M. Jantzen and N. R. Bibler (Jantzen and Bibler 1989). ${ }^{(a)}$ The test is a seven-day modified MCC-3 test that uses crushed glass in the size range $-100+200$ mesh with deionized water in a Teflon container. There is no agitation during the PCT, and no attempt to exclude $\mathrm{CO}_{2}$ from the test environment.

Based on B and Li release, the glasses performed about the same as in previous modified MCC-3 testing performed in FY 1987 and FY 1988 (Reimus et al. 1988). The modified MCC-3 tests performed by Reimus et al. were similar to the PCT except for a small amount of agitation of the containers and the exclusion of $\mathrm{CO}_{2}$ from the tests.

(a) Jantzen, C. M., and N. E. Bibler. 1989. "Nuclear Waste Glass Product Consistency Test (PCT) Method." Version 3.0. Westinghouse Savannah River Co., Aiken, South Carolina. 



\section{Contents}

Summary $\ldots \ldots \ldots \ldots \ldots \ldots \ldots \ldots \ldots \ldots \ldots \ldots \ldots \ldots \ldots \ldots$ iii

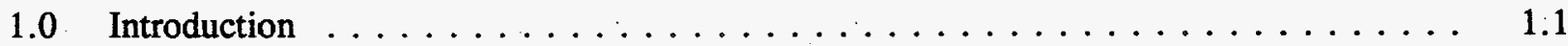

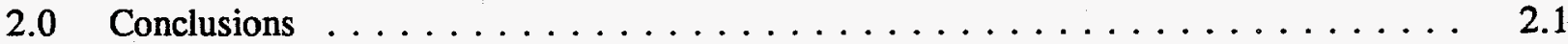

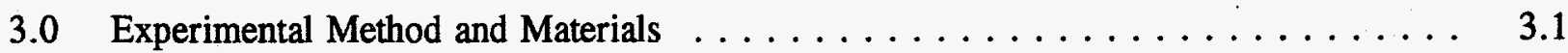

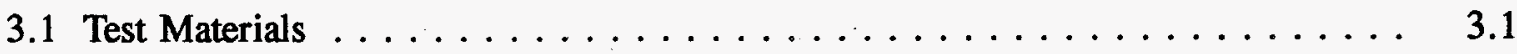

3.2 Test Procedure $\ldots \ldots \ldots \ldots \ldots \ldots \ldots \ldots \ldots \ldots \ldots \ldots \ldots \ldots$

3.3 Leachate Analysis $\ldots \ldots \ldots \ldots \ldots \ldots \ldots \ldots \ldots \ldots \ldots \ldots \ldots$

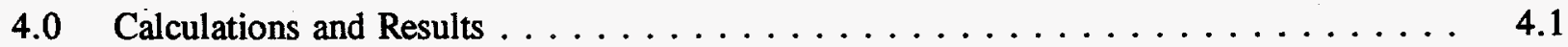

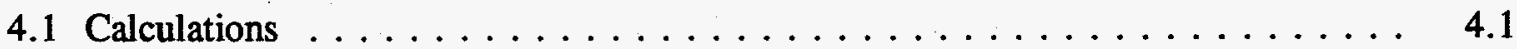

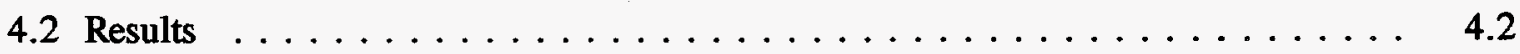

4.2.1 First Set of Compositional Variation Glasses: 8 Glasses, FY $1987 \ldots \ldots$. . 4.2

4.2.2 Redox Variation Glasses: 4 Glasses, FY $1987 \ldots \ldots \ldots \ldots \ldots \ldots$

4.2.3 Second Set of Compositional Variation Glasses: 16 Glasses, FY $1987 \ldots \ldots$

4.2.4 Compositional Variation Glasses: 16 Glasses, FY $1988 \ldots \ldots \ldots \ldots$

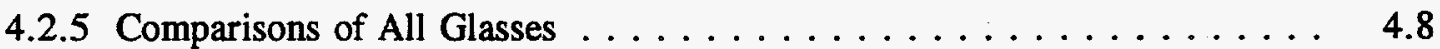

4.3 Duplicate Tests $\ldots \ldots \ldots \ldots \ldots \ldots \ldots \ldots \ldots \ldots \ldots \ldots \ldots$

4.4 Arm-1 Reference Glass Tests $\ldots \ldots \ldots \ldots \ldots \ldots \ldots \ldots \ldots \ldots$

4.5 Leachate $\mathrm{pH} \ldots \ldots \ldots \ldots \ldots \ldots \ldots \ldots \ldots \ldots \ldots \ldots \ldots$

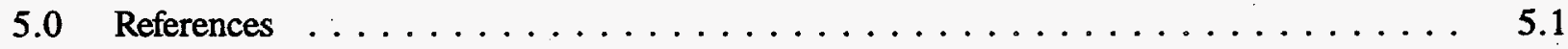

Appendix A - Product Consistency Test Information and Results $\ldots \ldots \ldots \ldots \ldots$. . . . . 


\section{Figures}

4.1 Normalized Elemental Mass Loss of B, Li, and Si for First Set of FY 1987 Compositional Variation Glasses (8 Glasses, WVDG-1 to WVDG-8) . . . . . . . . . .

4.2 Normalized Elemental Mass Loss of B, Li, and Si for Redox Set of FY 1987 Compositional Variation Glasses (4 Glasses, WVDG-11R to WVDG-14R) . . . . . .

4.3 Normalized Elemental Mass Loss of B, Li, and Si for Second Set of FY 1987 Compositional Variation Glasses (8 Glasses, WVDG-15 to WVDG-22) . . . . . . . .

4.4 Normalized Elemental Mass Loss of B, Li, and Si for Second Set of FY 1987 Compositional Variation Glasses (8 Glasses, WVDG-23 to WVDG-30)

4.5 Normalized Elemental Mass Loss of B, Li, and Si for Set of FY 1988

Compositional Variation Glasses (8 Glasses, WVDG-33 to WVDG-40)

4.6 Normalized Elemental Mass Loss of B, Li, and Si for Set of FY 1988

Compositional Variation Glasses (8 Glasses, WVDG-41 to WVDG-48)

4.7a Normalized Elemental Mass Loss of B from all 44 Test Glasses, Results from PCT Tests.

4.7b Normalized Elemental Mass Loss of B from all 44 Test Glasses, Results from Modified MCC-3 Testing Performed by Reimus et al. (1988). . . . . . . . . . .

4.8a Normalized Elemental Mass Loss of Li from all 44 Test Glasses, Results from PCT Tests. . . . . . . . . . . . . . . . . . . .

4.8b Normalized Elemental Mass Loss of Li from all 44 Test Glasses, Results from Modified MCC-3 Testing Performed by Reimus et al. (1988).

4.9a Normalized Elemental Mass Loss of Si from all 44 Test Glasses, Results from PCT Tests. . . . . . . . . . . . . . . . . . . . .

4.9b Normalized Elemental Mass Loss of Si from all 44 Test Glasses, Results from Modified MCC-3 Testing Performed by Reimus et al. (1988).

4.10a Normalized Elemental Mass Loss of U from all 44 Test Glasses, Results from PCT Tests

4.10b Normalized Elemental Mass Loss of U from all 44 Test Glasses, Results from Modified MCC-3 Testing Performed by Reimus et al. (1988).

4.11 Normalized Release of B, Li, and Si from Nearly Duplicate Glasses, WVDG-30,

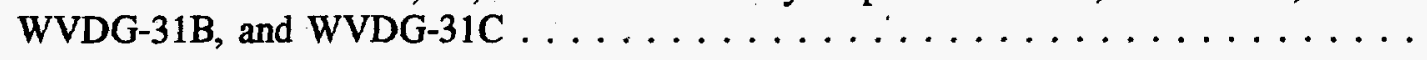

4.12 Leachate $\mathrm{pH}$ from 44 Test Glasses $\ldots \ldots \ldots \ldots \ldots \ldots \ldots$ 


\section{Tables}

3.1 Matrix for PCT of West Valley Compositional Variation Glasses . . . . . . . . . . 3.1

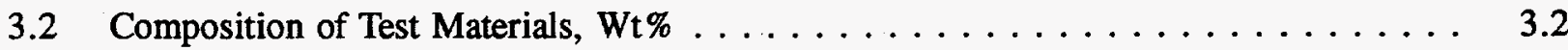

3.3 Definition of Compositional Variation Region Based on WVCM-50 $\ldots \ldots \ldots$

3.4 Definition of Compositional Variation Region Based on WV-8801, Wt\% . . . . . 3.9

4.1 Normalized Elemental Releases $\left(\mathrm{g} / \mathrm{m}^{2}\right)$ from First Set of FY 1987

Compositional Variation Glasses . . . . . . . . . . . . . . . . 4.2

4.2 Normalized Elemental Releases $\left(\mathrm{g} / \mathrm{m}^{2}\right)$ from Redox Set of FY 1987

Compositional Variation Glasses . . . . . . . . . . . . . . . . . 4.4

4.3 Normalized Elemental Releases $\left(\mathrm{g} / \mathrm{m}^{2}\right)$ from Second Set of FY 1987

Compositional Variation Glasses . . . . . . . . . . . . . . . . . . 4.6

4.4 Normalized Elemental Releases $\left(\mathrm{g} / \mathrm{m}^{2}\right)$ from FY 1988 Composition

Variation Glasses . . . . . . . . . . . . . . . . . . . . . . . . . 4.9

4.5 Normalized Elemental $\left(\mathrm{g} / \mathrm{m}^{2}\right)$ Releases from Three Glasses Having

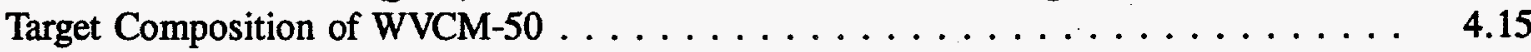

4.6 Normalized Elemental Releases from ARM-1 Reference Tests

Accompanying West Valley PCT Tests . . . . . . . . . . . . . . . 


\subsection{Introduction}

West Valley Nuclear Services (WVNS) must show that the nuclear waste glass produced by the West Valley Demonstration Project will be acceptable for disposal. In particular, WVNS must demonstrate compliance with the requirements of the Waste Acceptance Preliminary Specifications (WAPS) $^{(a)}$ that are being developed by the U.S. Department of Energy (DOE). The Materials Characterization Center (MCC) at Pacific Northwest Laboratory (PNL) ${ }^{\text {(b) }}$ will assist WVNS with technical expertise, facilities, and equipment to fully characterize the glasses produced in their vitrification system and to evaluate the chemical durability and performance of these glasses with respect to WAPS requirements.

The objective of this portion of MCC support to WVNS was to evaluate, using the Product Consistency Test (PCT), the 44 glasses fabricated and evaluated by the West Valley Support Task at PNL during FY 1987 and FY 1988. During those years, the glasses were tested using a modified MCC-3 test that required a small amount of agitation and exclusion of $\mathrm{CO}_{2}$. However, the WAPS now contains specific references to the PCT and the resulting $\mathrm{B}, \mathrm{Li}$, and $\mathrm{Na}$ releases from proposed nuclear waste glasses. Therefore, the 44 glasses were retested using the PCT method.

Included in the matrix were two nearly duplicate glasses and the MCC reference glass, Approved Reference Material-1 (ARM-1), which was used since the WSRC Environmental Assessment (EA) reference glass was not yet available. (The acceptance standard specified in WAPS 1.3 is EA glass).

The PCT was originated at the Westinghouse Savannah River Company (WSRC) by C. M. Jantzen and N. E. Bibler (Jantzen and Bibler 1989) ${ }^{(\mathfrak{c})}$ and was designed to require less time than the previously used MCC-1 test. Despite the shorter time requirement, the PCT successfully tests the product quality of the glass, while maintaining ease of sample preparation and procedures for radioactive glass and remote operation. The test is a seven-day modified $\mathrm{MCC}-3$ test that uses crushed glass in the size range $-100+200$ mesh. There is no agitation during the test and no attempt to exclude $\mathrm{CO}_{2}$ from the tests.

The data presented in this report were produced as part of West Valley's program to demonstrate the chemical durability of their waste glass and, therefore, its suitability for long-term disposal. These data are expected to be part of a data set that West Valley will use to support their Waste Form Qualification activities.

(a) U.S. Department of Energy. 1990. "Waste Acceptance Preliminary Specifications for Vitrified High-Level Waste Forms." (Draft copy), Office of Civilian Radioactive Waste Management, U.S. Department of Energy, Washington, D.C.

(b) Pacific Northwest Laboratory is operated for the U.S. Department of Energy by Battelle Memorial Institute under Contract DE-ACO6-76RLO 1830.

(c) Jantzen, C. M., and N. E. Bibler. 1989. "Nuclear Waste Glass Product Consistency Test (PCT) Method." Version 3.0. Westinghouse Savannah River Co., Aiken, South Carolina. 
This testing was performed at Quality Assurance (QA) Impact Level II in accordance with the PNL QA program, PNL-MA-70, and the MCC QA plan currently in effect. The procedure for this testing was specified in a test instruction and the technical procedure MCC-TP-19, Rev. 0, "Leaching Tests Using the PCT Test Method." Quality assurance verification activities included an audit by PNL during December 1990.

Following the conclusions, this report discusses test methods and materials and calculations and results. Appendix A includes information and analytical results from these tests. 


\subsection{Conclusions}

The 44 West Valley doped glasses from separate sets of Compositional Variation Glasses (CVG) of 1987 and 1988 were tested using the PCT. Conclusions were drawn by observing and comparing the normalized releases $\left(\mathrm{g} / \mathrm{m}^{2}\right)$ of $\mathrm{B}$ and $\mathrm{Li}$ from the glasses. Boron and $\mathrm{Li}$ were targeted in this test because they are soluble even when large amounts of glass have been leached and because they are specified in the current WAPS (as is $\mathrm{Na}$ ). The conclusions can be summarized as follows:

- The releases of $\mathrm{B}$ and $\mathrm{Li}$ from the 44 glasses were similar to those observed during modified MCC-3 testing that was performed by PNL during FY 1987 and FY 1988. In the majority of cases, the difference in normalized releases was $\leq 10 \%$

- The WVDG-20 glass was the most chemically durable of the glasses while WVDG-35 exhibited the least chemical durability. These results were consistent with previous work conducted by Reimus et al. (1988). The WVDG-20 glass contained more $\mathrm{Al}_{2} \mathrm{O}_{3}$, more $\mathrm{B}_{2} \mathrm{O}_{3}$, less $\mathrm{Fe}_{2} \mathrm{O}_{3}$, less alkali oxides, and slightly more $\mathrm{SiO}_{2}$ than the WVDG-35.

- The reference glass, ARM-1, showed similar leaching during the three PCT series that were performed. This verifies the reproducibility of this test over the space of six weeks.

- Releases of B and Li from the reference glass, ARM-1, were much less than the releases from ARM-1 during PCT testing of the West Valley Sludge Glass-1 (WVSG-1). ${ }^{\text {(a) }}$ This is probably due to the fact that the crushed glass in the WVSG-1 series was not washed, as stipulated by a former version of the PCT, and therefore contained a large amount of fines.

- Releases of $U$ averaged about $22 \%$ higher than in the previously conducted tests (Reimus et al. 1988).

(a) Olson, K. M., M. L. Elliott, J. W. Shade, and H. D. Smith. 1990. "Fabrication, Characterization, and Evaluation of West Valley Sludge Glass-1 (WVSG-1), a Fully Radioactive Glass Made with High-Level Waste from the West Valley Demonstration Project." Letter report prepared by Pacific Northwest Laboratory, Richland, Washington. 


\subsection{Experimental Method and Materials}

The test matrix for these experiments is shown in Table 3.1. A series of 50 PCT tests, including the 44 West Valley glasses plus duplicates, ARM-1 tests, and blanks, was conducted three separate times at two-week intervals, as shown in Table 3.1. The test series were separately randomized, and these random orders were adhered to throughout testing and analysis. Each series began over a twoday period, and at the conclusion of each series, leachate analyses were performed during a single day.

\subsection{Test Materials}

A total of 44 test glasses plus 2 duplicates and 1 reference glass was tested. The analyzed compositions of these glasses appear in Table 3.2. All of these glasses were doped with Th and $U$, hence the name West Valley doped glass (WVDG), which is used to label the samples. The glasses were fabricated and originally tested in the four following groups:

- First Set of Compositional Variation Glasses, FY 1987

WVDG-1, WVDG-2, and WVDG-4 to WVDG-8 were based on the West Valley Ceramic Melter-47 (WVCM-47) glass composition. The composition of WVDG-1 was the same as WVCM-47 glass, and several components were changed individually, to create each of

Table 3.1. Matrix for PCT of West Valley Compositional Variation Glasses

Tests Began

Randomize 50 Tests:

25 Tests, single day

25 Tests, single day

Rerandomize 50 Tests:

25 Tests, single day

$25^{\circ}$ Tests, single day

Rerandomize 50 Tests:

25 Tests, single day

25 Tests, single day
Week 5

(Week of 11-26-90)
Week 1

(Week of 10-29-90)

Week 3

(Week of 11-12-90)
Tests Ended

ICP Analysis
Week 4

(Week of 11-19-90)
Week 2

(Week of 11-4-90)

Week 6

(Week of 12-3-90)

$12-20-90$ 
Table 3.2. Composition of Test Materials, Wt\%

Oxide

Component

WVDG-1 WVDG-2

WVDG-3 WVDG-4

WVDG-5

WVDG-6

WVDG-7

WVDG-8

WVDG-11R

WVDG-12R

WVDG-13R

$\mathrm{Al}_{2} \mathrm{O}$,

$\mathrm{B}_{2} \mathrm{O}_{3}$

8.74
12.15

8.61
12.17

7.16
9.33

8.38

6.90

8.55
12.15

8.84
12.15

9.01
7.51

\subsection{6}

$0.05 \quad 0.05$

0.05

0.05

7.51
0.05

10.46
10.97

10.52
10.82

0.05

10.82

0.05

$0.68 \quad 0.69$

$\begin{array}{ll}0.68 & 0.68 \\ 0.07 & 0.09\end{array}$

0.20

0.21
0.05

0.05

0.65

0.67

0.62

0.07

$\begin{array}{ll}\mathrm{CeO}_{2} & 0.07 \\ \mathrm{Cr}_{2} \mathrm{O}_{3} & 0.19\end{array}$

0.20
0.05

0.29
0.06

0.05

0.05

0.20

0.10

0.63

$\mathrm{CuO}$

$\mathrm{Fe}_{2} \mathrm{O}_{3}$
$\mathrm{~K}_{2} \mathrm{O}$

$\mathrm{K}_{2} \mathrm{O}$
$\mathrm{La} \mathrm{O}$,

$\mathrm{La}_{2} \mathrm{O}_{3}$
$\mathrm{Li}_{2} \mathrm{O}$

$\mathrm{MgO}$
$\mathrm{Li}$

$\mathrm{MnO}_{2}$

$\mathrm{MoO}_{3}$

$\mathrm{Na}_{2} \mathrm{O}$
$\mathrm{Nd}_{2} \mathrm{O}$

$\omega$

$\begin{array}{cc}11.74 & 11.72 \\ 1.16 & 0.91 \\ 0.04 & 0.04\end{array}$

10.81

11.06

11.91

11.55

1.92
0.05

1.71
0.04

1.50

11.55
0.70

0.04

.04

0.14

0.09

0.17

0.10

$\begin{array}{r}11.90 \\ \hline\end{array}$

1.27

12.29

1.71
0.03

2.67
0.03

0.03

1.76

1.71
1.29

1.29
1.30

0.01

1.35
1.36

1.36
0.01

1.71
1.29

1.29
1.30

1.30
0.01

$11.47 \quad 9.10$

$\begin{array}{ll}0.14 & 0.12\end{array}$

$\begin{array}{ll}0.14 & 0.12 \\ 0.27 & 0.30\end{array}$

$2.54 \quad 2.63$

$0.00 \quad 0.00$

$\begin{array}{ll}0.03 & 0.00 \\ 0.03 & 0.03\end{array}$

0.03
0.00

0.00

$$
\begin{aligned}
& 0.00 \\
& 0.00
\end{aligned}
$$

$$
0.00
$$

44.43

41.94
0.03

44.43
0.03

0.03
0.31

0.03

3.11
0.97

0.97
$0.57^{(a)}$

9.13

0.11

0.28

3.56

0.00
0.03

0.03
0.00

0.00
0.00

0.00
43.42

43.42
0.03

0.03
0.30

0.03

2.75
0.93

0.93
0.53

$0.02 \quad 0.02$

1.71

1.71
1.28

1.28
1.29

0.01

1.84

1.39
1.37

0.01

9.38

$\begin{array}{ll}8.68 & 9.38 \\ 0.09 & 0.13\end{array}$

0.28

2.51

2.51
0.00

0.00
0.03

0.00

0.00

43.03

43.03
0.03

0.29

0.03

3.83
0.96

0.96
0.46

0.46
0.02

0.30
2.68

2.68

0.00
0.03

0.03
0.00

0.00

45.83

45.83
0.03

0.32

0.03
2.75

2.75
1.01

1.01
0.58

0.58
0.02

2.63
1.25

1.25
1.32

0.01

9.52

0.07

0.31

2.48

0.01

0.03

0.01

0.08

40.61

0.03

0.31

0.03

2.20
0.95

0.95
0.63

0.02

\begin{tabular}{ll}
0.05 & 0.02 \\
0.57 & 0.46 \\
\hline
\end{tabular}

$\mathrm{ZrO}_{2}$

TOTAL (b)

$\frac{0.59}{99.99} \frac{0.56}{100.02}$

$\frac{0.64}{99.99}$

$\frac{0.54}{100.00}$

$\frac{0.60}{100.00}$

$\frac{0.56}{100.01}$

$\frac{0.62}{100.01}$

9.97

$\frac{0.46}{99.99}$

11.82

2.85

0.03

2.57

1.25

1.31

0.01

9.58

0.08

0.29

2.52

0.01

0.03

0.01

0.08

40.16

0.03

0.30

0.03

2.53

0.94

0.65

0.01

\begin{tabular}{l}
0.06 \\
0.54 \\
\hline
\end{tabular}

99.99

10.58

10.78

0.05

0.61

0.07

0.17

0.12

11.90

2.87

0.03

2.59

1.26

1.31
0.01

9.38 .

0.09

0.31

2.50

0.01

0.01

0.08

40.18

0.03

0.31

0.03

2.48

0.69

0.02

(a) The $\mathrm{UO}_{2}$ value was set to the target value because the analytical value was not available.

(b) Totals do not equal 100 because of rounding errors. 
Table 3.2. (contd)

Oxide

Component

\begin{tabular}{|c|c|c|}
\hline Component & WDOKETI & WVDUED \\
\hline $\mathrm{Al}_{2} \mathrm{O}_{3}$ & 10.58 & 9.60 \\
\hline $\mathrm{B}_{2} \mathrm{O}_{3}$ & 10.98 & 12.58 \\
\hline $\mathrm{BaO}$ & 0.05 & 0.33 \\
\hline $\mathrm{CaO}$ & 0.61 & 1.36 \\
\hline $\mathrm{CeO}_{2}$ & 0.07 & 1.24 \\
\hline $\mathrm{Cr}_{2} \mathrm{O}_{3}$ & 0.17 & 0.24 \\
\hline $\mathrm{Cs}_{2} \mathrm{O}$ & 0.13 & 0.12 \\
\hline $\mathrm{CuO}$ & 0.07 & 0.02 \\
\hline $\mathrm{Fe}_{2} \mathrm{O}_{3}$ & 11.99 & 8.80 \\
\hline $\mathrm{K}_{2} \mathrm{O}$ & 2.19 & 1.64 \\
\hline $\mathrm{La}_{2} \mathrm{O}_{3}$ & 0.03 & 0.07 \\
\hline $\mathrm{Li}_{2} \mathrm{O}$ & 2.61 & 2.73 \\
\hline $\mathrm{MgO}$ & 1.25 & 1.27 \\
\hline $\mathrm{MnO}_{2}$ & 1.31 & 2.51 \\
\hline $\mathrm{MoO}_{3}$ & 0.01 & 0.07 \\
\hline $\mathrm{Na}_{2} \mathrm{O}$ & 9.51 & 10.17 \\
\hline $\mathrm{Nd}_{2} \mathrm{O}_{3}$ & 0.08 & 0.24 \\
\hline $\mathrm{NiO}$ & 0.29 & 0.53 \\
\hline $\mathrm{P}_{2} \mathrm{O}_{5}$ & 2.50 & 1.33 \\
\hline $\mathrm{PdO}_{2}$ & 0.01 & \\
\hline $\mathrm{Pr}_{6} \mathrm{O}_{11}$ & 0.03 & 0.07 \\
\hline $\mathrm{RhO}_{2}$ & 0.01 & \\
\hline $\mathrm{RuO}_{2}$ & 0.08 & \\
\hline $\mathrm{SiO}_{2}$ & 40.20 & 39.79 \\
\hline $\mathrm{Sm}_{2} \mathrm{O}_{3}$ & 0.03 & 0.03 \\
\hline $\mathrm{SO}_{3}$ & 0.30 & 0.40 \\
\hline Sró & 0.03 & 0.03 \\
\hline $\mathrm{ThO}_{2}$ & 2.59 & 1.66 \\
\hline $\mathrm{TiO}_{2}$ & 0.96 & 1.44 \\
\hline $\mathrm{UO}_{2}$ & 0.64 & 0.92 \\
\hline $\mathrm{Y}_{2} \mathrm{O}_{3}$ & 0.02 & 0.03 \\
\hline $\mathrm{ZnO}$ & & 0.02 \\
\hline $\mathrm{ZrO}_{2}$ & 0.73 & 0.69 \\
\hline TOTAL() & 99.99 & 100.01 \\
\hline
\end{tabular}

WVDG-16

9.43

12.61

0.32

1.37

0.38

0.07

0.04

0.08

14.42

1.31

0.02

1.91

1.22

2.23

0.02

8.64

0.07

0.16

3.23

0.02

39.95

0.01

0.12

0.01

1.60

0.44

0.13

0.01

0.02

$\frac{0.21}{99.99}$
WVDG-17

9.43
9.78

1.43

1.36

0.26 .

0.13

0.02

$$
8.87
$$

2.07

0.08

2.34
1.29

1.29
2.49

2.49
0.08

10.57

0.26

0.58

1.24

0.08

39.57

0.04

$$
\begin{aligned}
& 0.43 \\
& 0.04 \\
& 4.69 \\
& 1.58
\end{aligned}
$$$$
1.58
$$$$
0.08
$$$$
0.04
$$$$
0.75
$$

100.02

WVDG-18 WVDG-19

$\begin{array}{ccc}9.47 & & 12.23 \\ 10.62 & & 10.08\end{array}$

WVDG-20 WVDG-21

$\begin{array}{ll}0.11 & 0.32\end{array}$

$\begin{array}{ll}0.11 & 0.32 \\ 0.54 & 1.31\end{array}$

$\begin{array}{ll}0.54 & 1.31 \\ 0.39 & 0.38\end{array}$

$\begin{array}{ll}0.08 & 0.38 \\ 0.04 & 0.07\end{array}$

$\begin{array}{ll}0.04 & 0.04 \\ 0.02 & 0.07\end{array}$

$14.44 \quad 14.20$

$\begin{array}{ll}1.75 & 1.97\end{array}$

$0.02 \quad 0.02$

$2.44 \quad 2.07$

$0.44 \quad 1.28$

$0.54 \quad 0.50$

$\begin{array}{ll}0.02 & 0.02\end{array}$

$\begin{array}{ll}0.02 & 9.88\end{array}$

$0.08 \quad 0.07$

$0.17 \quad 0.16$

$1.55 \quad 1.35$

0.02

0.02

$43.20 \quad 36.01$

$0.01 \quad 0.01$

0.01

$0.13 \ldots-0.12$
$0.01-\quad 0.01$

0.01
1.96

0.46

0.01
5.24

$$
5.24
$$

0.44

$0.09 \quad 0.93$

$\begin{array}{ll}0.09 & 0.93 \\ 0.01 & 0.01\end{array}$

$\frac{0.22}{99.99} \frac{0.21}{98.99}$

\begin{tabular}{ccc}
39.95 & & 37.54 \\
0.04 & & 0.01 \\
0.43 & & 0.12 \\
0.04 & & 0.01 \\
1.87 & & 1.59 \\
1.57 & & 0.46 \\
0.95 & & 0.92 \\
0.04 & & 0.01 \\
0.02 & & 0.06 \\
0.75 & & 0.22 \\
\hline 100.00 & & 99.99
\end{tabular}

WVDG-22

WVDG-23

12.24
10.62

$12.51^{\circ}$
10.05

12.50

9.42
12.48

$\begin{array}{llll}0.31 & 0.11 & 0.11 & 0.11\end{array}$

$\begin{array}{llll}1.34 & 0.50 & 0.50 & 0.50\end{array}$

$\begin{array}{llll}1.35 & 0.39 & 1.32 & 0.42\end{array}$

$\begin{array}{llll}0.26 & 0.08 & 0.26 & 0.08\end{array}$

$\begin{array}{llll}0.13 & 0.04 & 0.13 & 0.04\end{array}$

$0.02 \quad 0.07$

$8.75 \quad 14.67$

2.23

0.07

2.04
1.42

0.52

0.07
8.63

0.26

0.58

$\mathbf{3 . 3 4}$

1.23

$\begin{array}{cc}0.02 & \\ 14.03 & 14.24\end{array}$

$1.84 \quad 1.86$

$\begin{array}{lll}0.02 & 0.07 & 0.02\end{array}$

$\begin{array}{lll}2.31 & 1.82 & 1.80\end{array}$

$\begin{array}{lll}0.53 & 0.48 & 0.54\end{array}$

$2.50 \quad 2.46 \quad 0.51$

$\begin{array}{lll}0.02 & 0.07 & 0.02\end{array}$

$\begin{array}{lll}10.46 & 8.31 & 8.23\end{array}$

$\begin{array}{lll}0.08 & 0.26 & 0.08\end{array}$

$\begin{array}{lll}0.17 & 0.57 & 0.18\end{array}$

$\begin{array}{lll}0.17 & 0.57 & 0.18 \\ 3.38 & 1.43 & 3.30\end{array}$

0.07

0,02

0.07

0.02

(a) Totals do not equal 100 because of rounding errors. 
Table 3.2. (contd)

\begin{tabular}{|c|c|c|c|c|c|c|c|c|c|c|c|}
\hline & $\begin{array}{c}\text { Oxide } \\
\text { Component }\end{array}$ & WVDG-24 & WVDG-25 & WVDG-26 & WVDG-27 & WVDG-28 & WVDG-29 & WVDG-30 & WVDG-31B & WVDG-31C & WVDG-33 \\
\hline & $\mathrm{Al}_{2} \mathrm{O}_{3}$ & 12.32 & 9.30 & 12.27 & 12.17 & 9.68 & 9.28 & 10.07 & 10.99 & 11.14 & 8.22 \\
\hline & $\mathrm{B}_{2} \mathrm{O}_{3}$ & 13.22 & 10.90 & 13.38 & 12.58 & 10.66 & 11.45 & 11.88 & 10.71 & 10.32 & 9.03 \\
\hline & $\mathrm{BaO}$ & 0.11 & 0.10 & 0.30 & 0.11 & 0.11 & 0.32 & 0.20 & 0.05 & 0.05 & 0.06 \\
\hline & $\mathrm{CaO}$ & 0.48 & 0.50 & 1.34 & 0.49 & 0.48 & 1.33 & 0.84 & 0.63 & 0.61 & 0.40 \\
\hline & $\mathrm{CeO}_{2}$ & 0.40 & 0.44 & 0.45 & 1.44 & 1.38 & 0.44 & 0.80 & 0.03 & 0.06 & 0.67 \\
\hline & $\mathrm{Cr}_{2} \mathrm{O}_{3}$ & 0.08 & 0.08 & 0.09 & 0.28 & 0.27 & 0.08 & 0.16 & 0.18 & 0.17 & 0.13 \\
\hline & $\mathrm{Cs}_{2} \mathrm{O}$ & 0.04 & 0.04 & 0.04 & 0.14 & 0.13 & 0.04 & 0.08 & 0.06 & 0.06 & 0.07 \\
\hline & $\mathrm{CuO}$ & 0.02 & 0.02 & 0.03 & 0.08 & 0.08 & 0.02 & 0.04 & 0.01 & 0.00 & 0.04 \\
\hline & $\mathrm{Fe}_{2} \mathrm{O}_{3}$ & 8.67 & 8.67 & 8.67 & 8.68 & 12.11 & 8.74 & 11.48 & 11.93 & 11.65 & 11.45 \\
\hline & $\mathrm{K}_{2} \mathrm{O}$ & 2.52 & 2.02 & 2.64 & 2.45 & 1.35 & 1.84 & 1.81 & 2.74 & 3.04 & 3.44 \\
\hline & $\mathrm{La}_{2} \mathrm{O}_{3}$ & 0.02 & 0.02 & 0.03 & 0.08 & 0.08 & 0.02 & 0.04 & 0.03 & 0.04 & 0.04 \\
\hline & $\mathrm{Li}_{2} \mathrm{O}$ & 2.05 & 2.03 & 2.00 & 2.28 & 2.05 & 2.57 & 2.10 & 2.56 & 2.50 & 2.91 \\
\hline & $\mathrm{MgO}$ & 0.56 & 0.53 & 1.35 & 0.62 & 0.62 & 1.36 & 1.01 & 1.25 & 1.29 & 0.98 \\
\hline & $\mathrm{MnO}_{2}$ & 2.44 & 2.40 & 0.55 & 0.51 & 0.52 & 0.50 & 1.20 & 1.31 & 1.28 & 1.28 \\
\hline & $\mathrm{MoO}_{3}$ & 0.02 & 0.02 & 0.03 & 0.08 & 0.08 & 0.02 & 0.04 & 0.00 & 0.00 & 0.04 \\
\hline & $\mathrm{Na}_{2} \mathrm{O}$ & 9.56 & 9.09 & 9.09 & 10.14 & 8.86 & 10.74 & 9.63 & 9.47 & 9.24 & 10.51 \\
\hline & $\mathrm{Nd}_{2} \mathrm{O}_{3}$ & 0.08 & 0.08 & 0.09 & 0.28 & 0.27 & 0.08 & 0.16 & 0.12 & 0.14 & 0.13 \\
\hline & $\mathrm{NiO}$ & 0.17 & 0.19 & 0.19 & 0.62 & 0.59 & 0.19 & 0.35 & 0.34 & 0.32 & 0.29 \\
\hline i & $\mathrm{P}_{2} \mathrm{O}_{3}$ & 1.41 & 3.13 & 1.62 & 3.48 & 1.53 & 3.27 & 2.42 & 2.54 & 2.56 & 2.47 \\
\hline & $\mathrm{PdO}_{2}$ & & & & & & & & 0.01 & 0.01 & \\
\hline & $\mathrm{Pr}_{6} \mathrm{O}_{11}$ & 0.02 & 0.02 & 0.03 & 0.08 & 0.08 & 0.02 & 0.04 & 0.03 & 0.03 & 0.04 \\
\hline & $\mathrm{RhO}_{2}$ & & & & & & & & 0.01 & 0.01 & \\
\hline & $\mathrm{RuO}_{2}$ & & & & & & & & 0.08 & 0.08 & \\
\hline & $\mathrm{SiO}_{2}$ & 42.10 & 45.00 & 40.95 & 36.72 & 43.38 & 44.68 & 40.06 & 42.39 & 39.77 & $42.50^{(n)}$ \\
\hline & $\mathrm{Sm}_{2} \mathrm{O}_{3}$ & 0.01 & 0.01 & 0.01 & 0.04 & 0.04 & 0.01 & 0.02 & 0.03 & 0.03 & 0.02 \\
\hline & $\mathrm{SO}_{3}$ & 0.13 & 0.14 & 0.14 & 0.46 & 0.44 & 0.14 & 0.26 & 0.30 & 0.31 & 0.21 \\
\hline & $\mathrm{SrO}$ & 0.01 & 0.01 & 0.01 & 0.04 & 0.04 & 0.01 & 0.02 & 0.03 & 0.03 & 0.02 \\
\hline & $\mathrm{ThO}_{2}$ & 1.88 & 4.36 & 3.80 & 3.46 & 1.72 & 1.93 & 3.26 & 2.33 & 3.28 & 3 \\
\hline & $\mathrm{TiO}_{2}$ & 0.47 & 0.51 & 0.53 & 1.68 & 1.61 & 0.51 & 0.94 & 0.92 & 0.92 & 0.78 \\
\hline & $\mathrm{UO}_{2}$ & 0.93 & 0.10 & 0.10 & 0.11 & 0.96 & 0.10 & 0.59 & 0.45 & 0.51 & 0 \\
\hline & $\mathrm{Y}_{2} \mathrm{O}_{3}$ & 0.01 & 0.01 & 0.01 & 0.04 & 0.04 & 0.01 & 0.02 & 0.02 & 0.02 & 0.02 \\
\hline & $\mathrm{ZnO}$ & 0.02 & & 0.02 & 0.06 & 0.06 & 0.02 & 0.03 & & & 0.03 \\
\hline & $\mathrm{ZrO}_{2}$ & 0.22 & 0.24 & 0.25 & 0.80 & 0.77 & 0.24 & 0.45 & 0.47 & 0.51 & 0.37 \\
\hline & TOTAL ${ }^{(b)}$ & 99.99 & 99.98 & 100.01 & 100.00 & 99.99 & 99.96 & 100.00 & 100.02 & 99.98 & 100.02 \\
\hline
\end{tabular}

(a) The $\mathrm{SiO}_{2}$ of WVDG-33 through WVDG-48 were set to the target values due to a relatively large bias in the ICP analysis of $\mathrm{SiO}{ }_{2}$. This was done per Reimus et al. (1988).

(b) Totals do not equal 100 because of rounding errors. 
Table 3.2. (contd)

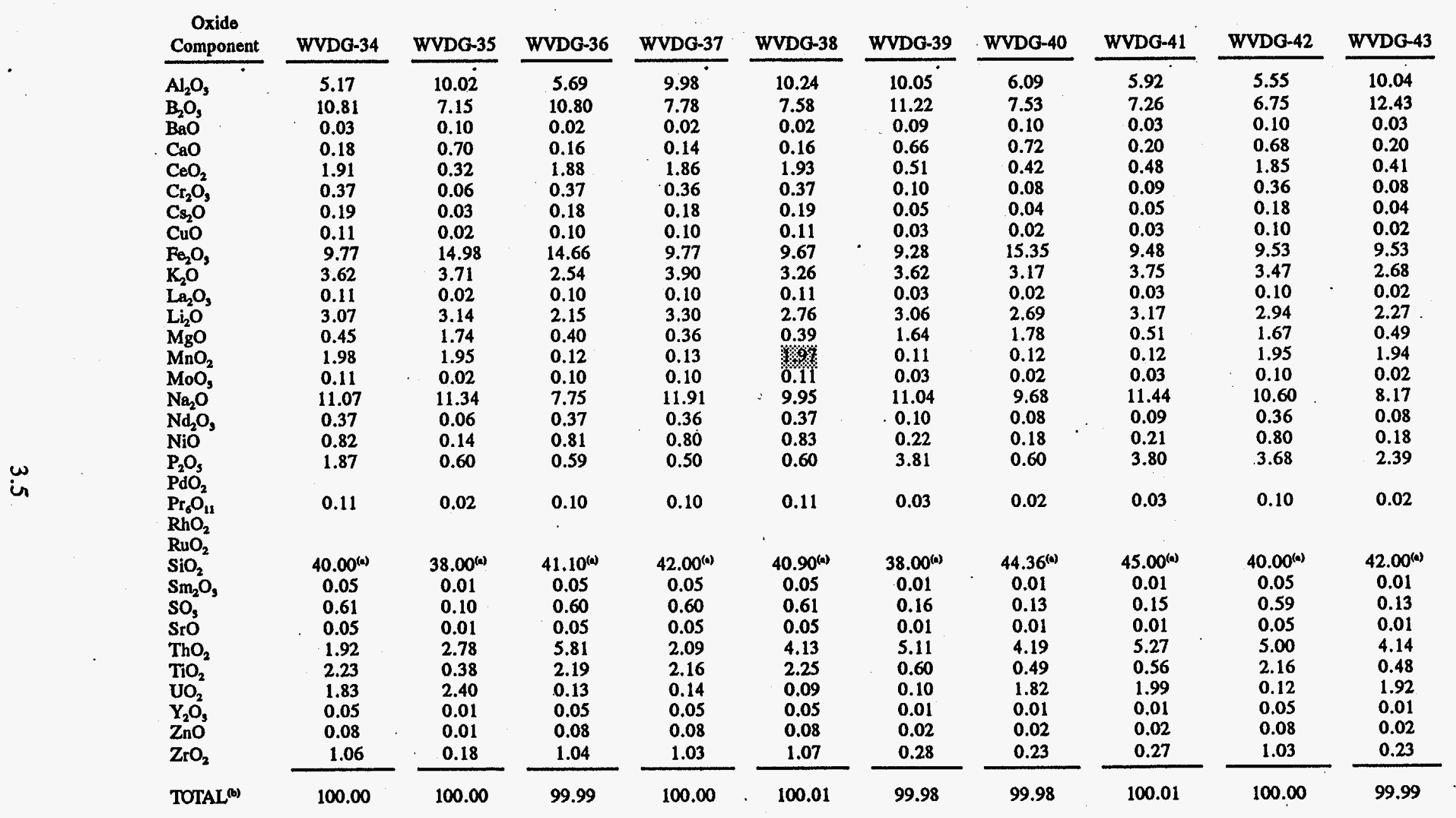

(a) The $\mathrm{SiO}_{2}$ of WVDG-33 through WVDG-48 were set to the target values due to a relatively large bias in the $\mathrm{ICP}$ analysis of $\mathrm{SiO}{ }_{2}$. This was done per Reimus et al. (1988)

(b) Totals do not equal 100 because of rounding errors. 
Table 3.2. (contd)

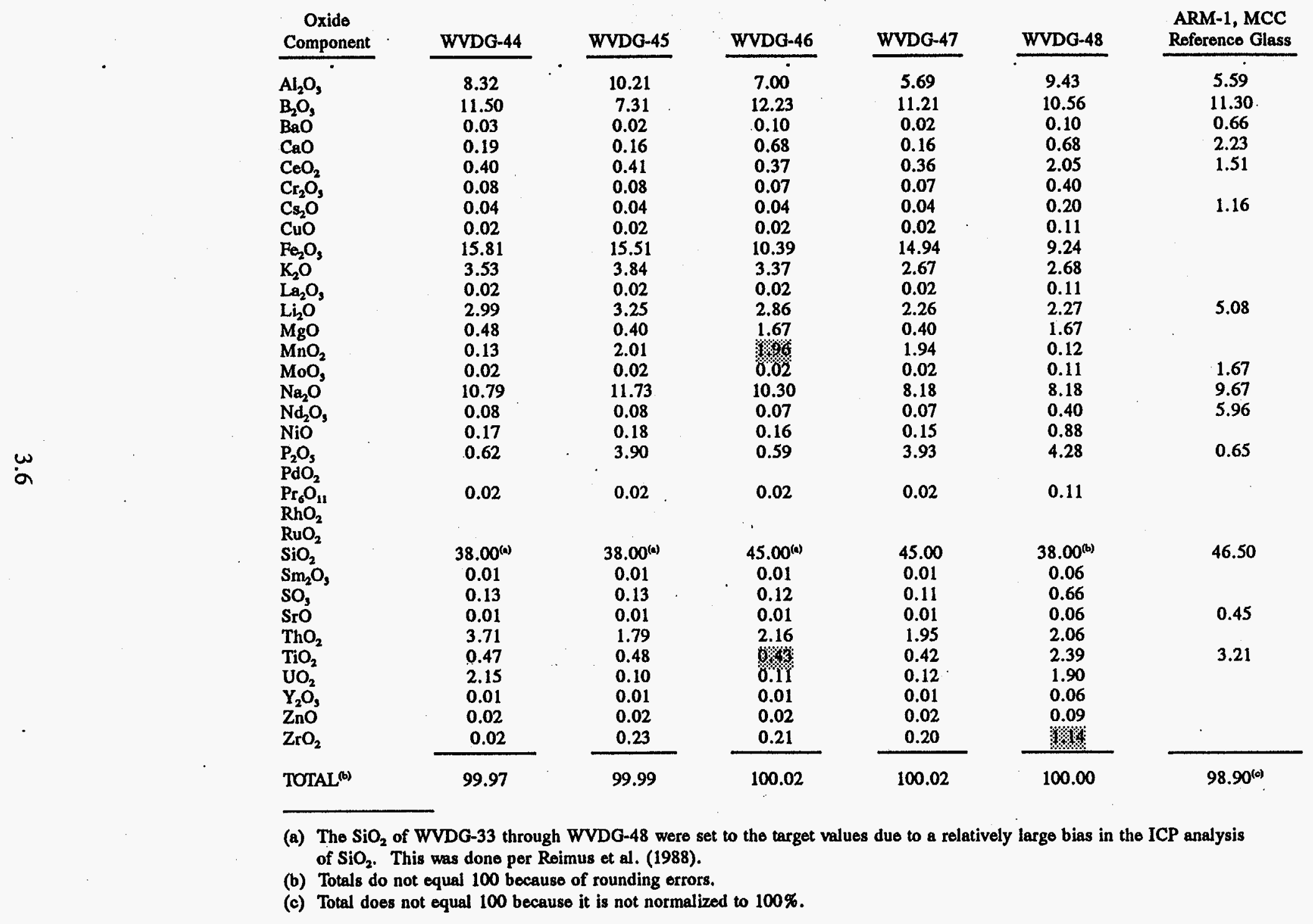


the glasses WVDG-4 to WVDG-8. The composition of WVDG-2 was the same as WVCM-47 with the addition of noble metal oxides. WVDG-3 was an alternate glass based on another West Valley reference glass, ATM-10.

- Redox Variation Glasses, FY 1987

WVDG-11R to WVDG-14R shared the same composition, which was close to that of WVCM50 , but the redox state of the glass varied. The $\mathrm{Fe}^{2+} / \mathrm{Fe}^{3+}$ ratio varied from 0.068 to 0.424 .

- Second Set of Compositional Variation Glasses, FY 1987

WVDG-15 to WVDG-30 were selected to explore a polyhedral region centered around the WVCM-50 glass composition. WVDG-30 was nominally the WVCM-50 composition, while the other compositions were 15 vertices of the polyhedral region. The oxide limits of this polyhedral region are shown in Table 3.3. (Two duplicates of WVDG-30, WVDG-31B and WVDG-31C were also included.)

- Compositional Variation Glasses, FY 1988

WVDG-33 to WVDG-48 were selected to explore a polyhedral region centered around the WV-8801 composition. Glass WVDG-33 was the WV-8801 composition, while the remaining glasses were 15 vertices of the polyhedral region. The oxide limits of this polyhedral region are shown in Table 3.4.

In addition to the test materials, ARM-1 was used as a test standard. The ARM-1 glass is a standard reference glass supplied by the MCC and is described by Mellinger and Daniel (1984).

The glass powders were prepared by breaking small amounts of glass into pieces using a Plattner tool-steel mortar. Next, the glass pieces were crushed with a mechanical mortar and pestle. The crushed glass was then shaken through 100- and 200-mesh brass sieves. Powder that did not pass through the 100-mesh sieve was ground further in the pulverizer. This process was repeated until all powder passed the 100-mesh sieve.

The sieved powders were washed seven times as specified in V.3.0 of the PCT. In the first two washes, fresh deionized water was squirted into the glass powders; settling was allowed for $15 \mathrm{~s}$, then the water was decanted. In the next two washes, the powders were placed in an ultrasonic cleaner with fresh deionized water. Decanting was performed after 2 min of ultrasonic cleaning. The three final washes were performed using fresh alcohol with the glass powders in an ultrasonic cleaner. Again, decanting was performed after $2 \mathrm{~min}$ of ultrasonic cleaning. The powders were dried overnight at $90^{\circ} \mathrm{C}$. 
Table 3.3. Definition of Compositional Variation Region Based on WVCM-50

\begin{tabular}{|c|c|c|}
\hline \multicolumn{3}{|c|}{ Single Component Constraints, wt\% } \\
\hline 9.0 & $\mathrm{Al}_{2} \mathrm{O}_{3}$ & $\leq 12.0$ \\
\hline$\leq$ & & \\
\hline 10.0 & $\mathrm{~B}_{2} \mathrm{O}_{3}$ & $\leq 14.0$ \\
\hline $\begin{array}{l}\leq \\
1.0\end{array}$ & $\mathrm{BaO}+\mathrm{CaO}+\mathrm{MgO}^{(\mathrm{a})}$ & $\leq 3.0$ \\
\hline $\begin{array}{l}\leq \\
9.0\end{array}$ & $\mathrm{Fe}_{2} \mathrm{O}_{3}$ & $\leq 15.0$ \\
\hline $\begin{array}{l}\leq \\
11.6\end{array}$ & $\mathrm{~K}_{2} \mathrm{O}+\mathrm{Li}_{2} \mathrm{O}+\mathrm{Na}_{2} \mathrm{O}^{(a)}$ & $\leq 15.6$ \\
\hline $\begin{array}{l}\leq \\
0.5\end{array}$ & $\mathrm{MnO}_{2}$ & $\leq 2.5$ \\
\hline$\leq$ & $\mathrm{P}_{2} \mathrm{O}_{5}$ & $\leq 3.5$ \\
\hline $\begin{array}{l}\leq \\
36.0 \\
\leq\end{array}$ & $\mathrm{SiO}_{2}$ & $\leq 44.0$ \\
\hline 2.0 & $\mathrm{ThO}_{2}$ & $\leq 5.25$ \\
\hline $\begin{array}{l}\leq \\
0.1\end{array}$ & $\mathrm{UO}_{2}$ & $\leq 1.0$ \\
\hline $\begin{array}{l}\leq \\
1.0 \\
\leq\end{array}$ & Others & $\leq 8.0$ \\
\hline Mul & ple Component Constraint & $w t \%$ \\
\hline $\begin{array}{l}48.0 \leq \\
23.6 \leq \\
3.3 \leq \\
3.7 \leq\end{array}$ & $\begin{array}{c}\mathrm{SiO}_{2}+\mathrm{Al}_{2} \mathrm{O}_{3} \\
\text { Alkalis }+\mathrm{B}_{2} \mathrm{O}_{3} \\
\left(\mathrm{SiO}_{2}+\mathrm{Al}_{2} \mathrm{O}_{3}\right) / \mathrm{Alkalis} \\
\left(\mathrm{SiO}_{2}+\mathrm{Al}_{2} \mathrm{O}_{3}\right) / \mathrm{B}_{2} \mathrm{O}_{3}\end{array}$ & $\begin{array}{l}\leq 54 \\
\leq 27.6 \\
\leq 4.1 \\
\leq 4.7\end{array}$ \\
\hline
\end{tabular}

(a) The $\mathrm{BaO}: \mathrm{CaO}: \mathrm{MgO}$ and $\mathrm{K}_{2} \mathrm{O}: \mathrm{Li}_{2} \mathrm{O}$ : $\mathrm{Na}_{2} \mathrm{O}$ wt\% ratios were held constant at their levels in the WVCM-50 glass. 
Table 3.4. Definition of Compositional Variation Region Based on WV-8801, Wt\%

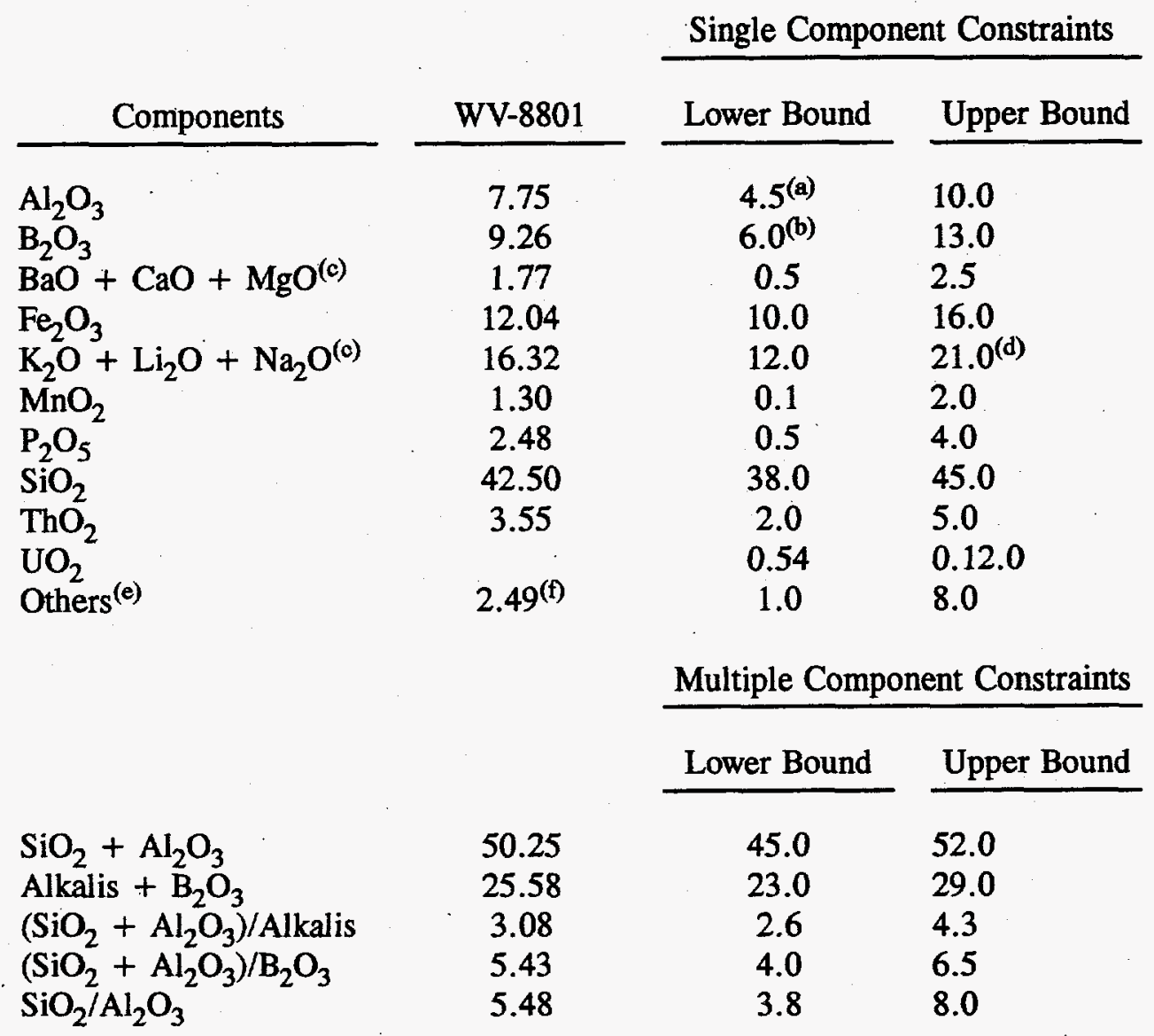

(a) Due to the multiple component constraints, the attainable lower limit for $\mathrm{Al}_{2} \mathrm{O}_{3}$ is $5 \mathrm{wt} \%$.

(b) Due to the multiple component constraints, the attainable lower limit for $\mathrm{B}_{2} \mathrm{O}_{3}$ is $6.92 \mathrm{wt} \%$.

(c) The $\mathrm{BaO}: \mathrm{CaO}: \mathrm{MgO}$ and $\mathrm{K}_{2} \mathrm{O}: \mathrm{Li}_{2} \mathrm{O}: \mathrm{Na}_{2} \mathrm{O}$ wt\% ratios were held constant at their levels in the WV-8801 glass.

(d) Due to the multiple component constraints, the attainable upper limit for alkalis is $20 \mathrm{wt} \%$.

(e) Includes the following oxide mix: $\mathrm{CeO}_{2}(6.35), \mathrm{Cr}_{2} \mathrm{O}_{3}(5.56), \mathrm{Cs}_{2} \mathrm{O}$ (3.57), $\mathrm{CuO}$ (2.38), $\mathrm{La}_{2} \mathrm{O}_{3}$ (1.59), $\mathrm{MoO}_{3}$ (1.98), $\mathrm{Nd}_{2} \mathrm{O}_{3}$ (5.56), $\mathrm{NiO}$ (9.92), $\mathrm{PdO}_{2}$ (1.19), $\mathrm{Pr}_{6} \mathrm{O}_{11}$ (1.59), $\mathrm{RhO}_{2}(0.79), \mathrm{RuO}_{2}$ (3.17), $\mathrm{Sm}_{2} \mathrm{O}_{3}$ (0.79), $\mathrm{SnO}_{2}(1.19), \mathrm{SO}_{3}(8.73), \mathrm{SrO}(0.79), \mathrm{TeO}_{2}(0.40)$, $\mathrm{TiO} 2$ (35.32), $\mathrm{Y}_{2} \mathrm{O}_{3}(0.79), \mathrm{ZuO}_{2}(0.79), \mathrm{ZrO}_{2}$ (7.54). Numbers in parentheses give relative wt\% of the oxides in this mix.

(f) This level for "Others" was obtained by subtracting from 100 the total w\% evels of the preceding ten components. 


\subsection{Test Procedure}

The PCT was originated at the Westinghouse Savannah River Company by C. M. Jantzen and N. R. Bibler (Jantzen and Bibler 1989). The test is a modified MCC-3 test that runs for seven days and uses crushed glass in the size range $-100+200$ mesh. The difference between the MCC- 3 and PCT is that there is no agitation during the PCT test, nor is $\mathrm{CO}_{2}$ excluded from the test environment.

Approximately $3 \mathrm{~g}$ of 100 - to 200 -mesh crushed glass and $30 \mathrm{~mL}$ of deionized water leachant were sealed inside a Teflon test vessel, in which the test temperature was $90^{\circ} \mathrm{C} \pm 2^{\circ} \mathrm{C}$. Atmospheric $\mathrm{CO}_{2}$ was not excluded from the test and the container was not agitated during the test. The Teflon containers were placed in an oven at $90^{\circ} \mathrm{C}$. The container lids were tightened within $24 \mathrm{~h}$ after being placed in the oven. Six containers cost $>10 \%$ of their leachant during the seven days of testing, most likely because crushed glass was present in the seal of the Teflon containers. Data from these six tests were not used.

\subsection{Leachate Analysis}

At the end of the seven-day cycle, the Teflon containers were removed from the oven, weighed, and allowed to cool. The Teflon leaching vessels were opened, and approximately $1 \mathrm{~mL}$ of leachate was removed from each for $\mathrm{pH}$ measurement using a Ross combination electrode. These 1-mL portions of leachate were discarded after the $\mathrm{pH}$ measurements were taken.

The remaining leachate from each vessel was filtered using a $0.45-\mu \mathrm{m}$ filter and split into three aliquots. Approximately $10 \mathrm{~mL}$ was acidified to $1 \%$ with Ultrex $\mathrm{HNO}_{3}$ and analyzed by inductively coupled plasma (ICP) spectrometry and laser fluorescence for U. Approximately $10 \mathrm{~mL}$ was sent without acidification for ion chromatograph (IC) analysis. The remaining leachate was acidified and stored for possible future analysis. 


\subsection{Calculations and Results}

This section presents the calculations and results from the PCT of the 44 West Valley Compositional Variation Glasses plus two duplicate glasses and the ARM-1 reference glass and blanks. Additional information and ICP analytical data from the PCT of these glasses are listed in the Appendix, Tables A.1 to A.3; data from U analyses are included in these Appendix tables. IC data are listed in Table A.4. Estimates of data variability using statistical error propagation techniques were not calculated due to time and budget constraints.

\subsection{Calculations}

Only normalized results, in units of $\mathrm{g} / \mathrm{m}^{2}$, are presented in this section. For a particular set of test conditions (i.e., a specified combination of time and glass composition), the normalized element mass loss of the $\mathrm{i}$-th element computed for the $\mathrm{j}$-th specimen $\left(\mathrm{NL}_{\mathrm{ij}}\right)$ is given by:

$$
N L_{i j}=\frac{C_{i j}-B_{i}}{f_{i}\left(S_{j} / V_{j}\right)}
$$

where $C_{i j}=$ concentration of element $\mathrm{i}$ observed in leachate from specimen $\mathrm{j}$

$B_{i}=$ concentration of element $\mathrm{i}$ observed in leachate from blank

$f_{i}=$ average mass fraction of element $i$ in the specimen, where $f_{i}=$ (mass fraction oxide in glass) (atomic weight metal in oxide)

atomic weight of oxide

$S_{j}=$ surface area of specimen $\mathrm{j}$

$V_{j}=$ initial volume of leachant in test vessel containing specimen $j$.

The ratio of $S / V$ (specimen surface area to leachant volume) was approximately $2000 \mathrm{~m}^{-1}$ for these PCTs. S/V was calculated for each sample from the mass of sample, using an assumed glass sample surface area of $0.02 \mathrm{~m}^{2} / \mathrm{g}$ and the actual volume of leachant. This assumed specific surface area of 100 - to 200 -mesh glass, $0.02 \mathrm{~m}^{2} / \mathrm{g}$, is based on an average-sized spherical particle of $0.055 \mathrm{~mm}$ and glass density of $2.7 \mathrm{~g} / \mathrm{cm}^{3}$.

Normalized releases are averages for the three tests of each glass, except in cases where one of the tests lost greater than $10 \%$ of its original leachant. In the six such cases, normalized values are averages for only two of the three tests. Generally, normalized values are given for all metals whose oxides constituted more than $1 \%$ of the glass composition. 


\subsection{Results}

The results are briefly discussed below, in the order in which the four sets of glasses were made in FY 1987 and FY 1988.

\subsubsection{First Set of Compositional Variation Glasses: 8 Glasses, FY 1987}

These glasses were based on the WVCM-47 composition, nominally the composition of WVDG-1. The glass WVDG-2 contained noble metal oxides and WVDG-3 was similar to ATM-10, a West Valley reference glass not included in the Compositional Variability Study. Single elements were changed in all of the other glasses in this set, with the remaining oxide percentages proportionally adjusted to offset the changes. Based on WVCM-47, WVDG-4 contained higher $\mathrm{Na}_{2} \mathrm{O}$; WVDG- 5 contained lower $\mathrm{Al}_{2} \mathrm{O}_{3}$; WVDG-6 contained higher $\mathrm{P}_{2} \mathrm{O}_{5}$; WVDG-7 contained higher $\mathrm{ThO}_{2}$; and WVDG-8 contained lower $\mathrm{B}_{2} \mathrm{O}_{3}$.

The averaged normalized release values from this set of glasses are listed in Table 4.1. The averaged release values for $\mathrm{B}, \mathrm{Li}$, and $\mathrm{Si}$ (Table 4.1) are plotted in Figure 4.1. Figure 4.1 shows normalized releases of $\mathrm{B}$ and $\mathrm{Li}$ as required by the WAPS (DOE 1990). The element $\mathrm{Si}$ is included

Table 4.1. Normalized Elemental Releases $\left(\mathrm{g} / \mathrm{m}^{2}\right)$ from First Set of FY 1987 Compositional Variation Glasses

\begin{tabular}{|c|c|c|c|c|c|c|c|c|}
\hline & WVDG-1 & WVDG-2 & WVDG-3 & WVDG-4 & WVDG-5 & WVDG-6 & WVDG-7 & WVDG-8 \\
\hline $\mathrm{Al}$ & 0.114 & 0.113 & 0.095 & 0.110 & 0.093 & 0.114 & 0.106 & 0.106 \\
\hline B & 0.180 & 0.207 & 0.238 & 0.261 & 0.214 & 0.199 & 0.180 & 0.173 \\
\hline $\mathrm{Fe}$ & 0.008 & 0.004 & 0.005 & 0.004 & 0.003 & 0.004 & 0.005 & 0.003 \\
\hline $\mathbf{K}$ & 0.101 & 0.140 & 0.095 & 0.075 & 0.102 & 0.179 & 0.163 & 0.087 \\
\hline $\mathbf{L i}$ & 0.250 & 0.311 & 0.291 & 0.303 & 0.285 & 0.303 & 0.267 & 0.273 \\
\hline $\mathrm{Mg}$ & 0.007 & 0.006 & 0.013 & 0.007 & 0.005 & 0.004 & 0.007 & 0.006 \\
\hline $\mathbf{M n}$ & 0.007 & 0.004 & 0.005 & 0.004 & 0.002 & 0.002 & 0.003 & 0.003 \\
\hline Mo & 0.171 & 0.193 & (a) & 0.229 & 0.249 & 0.188 & 0.201 & 0.176 \\
\hline $\mathrm{Na}$ & 0.159 & 0.181 & 0.233 & 0.266 & 0.198 & 0.169 & 0.169 & 0.174 \\
\hline $\mathbf{P}$ & 0.085 & 0.108 & 0.200 & 0.188 & 0.129 & 0.101 & 0.091 & 0.119 \\
\hline $\mathrm{Si}$ & 0.127 & 0.133 & 0.139 & 0.134 & 0.128 & 0.131 & 0.125 & 0.121 \\
\hline Th & 0.007 & 0.004 & & - & & & 0.003 & \\
\hline $\mathrm{Ti}$ & 0.006 & 0.003 & 0.002 & 0.002 & 0.002 & 0.003 & 0.003 & 0.002 \\
\hline $\mathrm{U}$ & 0.062 & 0.043 & 0.039 & 0.041 & 0.034 & 0.056 & 0.048 & 0.049 \\
\hline $\mathrm{pH}$ & 9.40 & 9.340 & 9.77 & 9.78 & 9.46 & 9.50 & 9.37 & 9.73 \\
\hline
\end{tabular}

(a) Absence of data indicates less than analytical detection limit. 


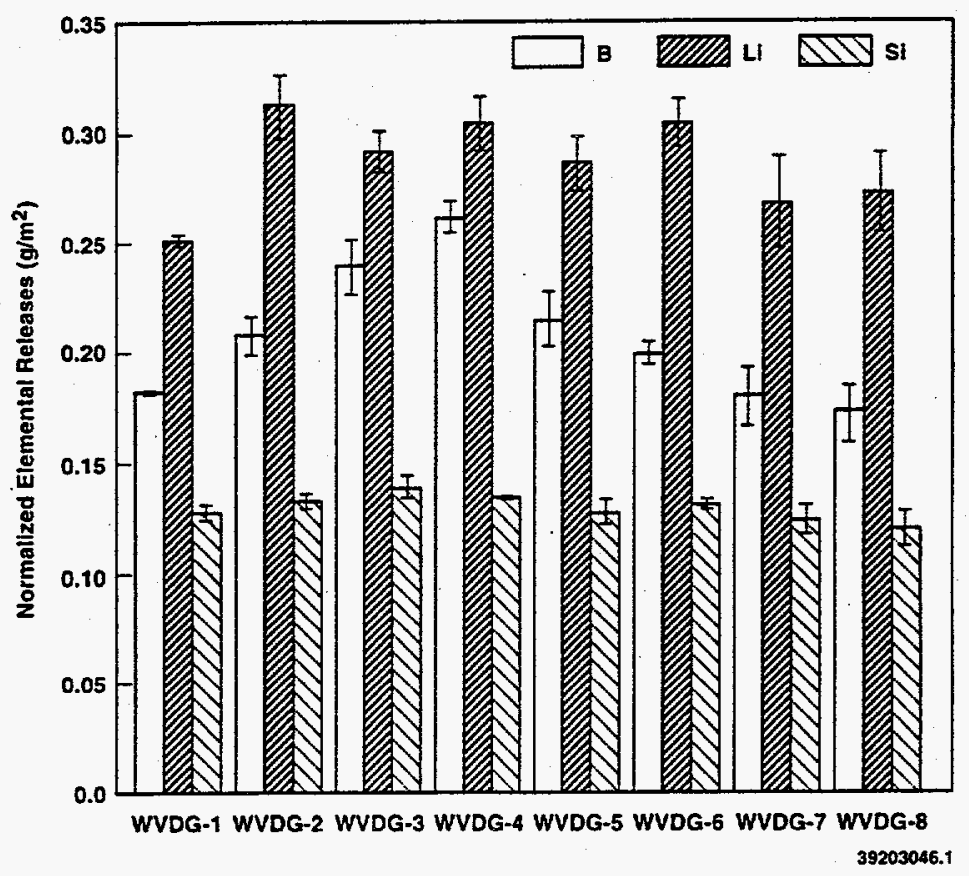

Figure 4.1. Normalized Elemental Mass Loss of B, Li, and Si for First Set of FY 1987 Compositional Variation Glasses (8 Glasses, WVDG-1 to WVDG-8). (Error bars are \pm 1 standard deviation taking into account variation in leachate concentrations only.)

because it was plotted by Reimus et al. (1988). The error bars are \pm 1 standard deviation based on variability of leachate values only, i.e., uncertainty in surface area/initial volume $(S / V)$, composition, and blank and volume corrections were not included. Uncertainty in $S / V$, glass composition, and blank and volume correctors would each be expected to add to the standard deviation. The uncertainty contribution from variations in S/V could be calculated from sample weight and leachant volume numbers recorded by laboratory personnel. Uncertainty from glass composition analysis was estimated for Reimus et al. (1988). The uncertainty from blank and volume corrections would need to be estimated.

As was found by Reimus et al. (1988), the least chemically durable glass in Figure 4.1 based on normalized release, appears to be WVDG-4, the "high $\mathrm{Na}_{2} \mathrm{O}$ " glass. Glasses WVDG-7 (high $\mathrm{ThO}_{2}$ ) and WVDG-8 (low $\mathrm{B}_{2} \mathrm{O}_{3}$ ) appear to be as chemically durable as the reference glass, WVDG-1. These comparisons are based on $B$ release. 


\subsubsection{Redox Variation Glasses: 4 Glasses, FY 1987}

The averaged normalized release values are listed in Table 4.2. The normalized releases for $\mathbf{B}, \mathbf{L i}$, and $\mathrm{Si}$ are plotted in Figure 4.2. There appears to be a trend toward higher releases with higher redox $\left(\mathrm{Fe}^{2+} / \mathrm{Fe}^{3+}\right)$ ratio; no similar trend was shown during previous testing by Reimus et al. (1988).

Table 4.2. Normalized Elemental Releases $\left(\mathrm{g} / \mathrm{m}^{2}\right)$ from Redox Set of FY 1987 Compositional Variation Glasses

\begin{tabular}{|c|c|c|c|c|}
\hline & WVDG-11R & WVDG-12R & WVDG-13R & WVDG-14R \\
\hline $\mathrm{Fe}^{2+} / \mathrm{Fe}^{3+}$ & 0.068 & 0.126 & 0.236 & 0.424 \\
\hline $\mathrm{Al}$ & 0.116 & 0.115 & 0.119 & 0.126 \\
\hline B & 0.205 & 0.217 & 0.237 & 0.288 \\
\hline $\mathrm{Fe}$ & 0.005 & 0.004 & 0.004 & 0.008 \\
\hline K & 0.134 & 0.131 & 0.127 & 0.195 \\
\hline $\mathbf{L i}$ & 0.246 & 0.263 & 0.279 & 0.333 \\
\hline $\mathrm{Mg}$ & 0.008 & 0.009 & 0.009 & 0.017 \\
\hline $\mathrm{Mn}$ & 0.005 & 0.004 & 0.004 & 0.008 \\
\hline Mo & 0.197 & 0.217 & 0.225 & 0.235 \\
\hline $\mathrm{Na}$ & 0.204 & 0.214 & 0.243 & 0.302 \\
\hline $\mathbf{P}$ & 0.168 & 0.164 & 0.178 & 0.201 \\
\hline $\mathrm{Si}$ & 0.122 & 0.123 & 0.128 & 0.136 \\
\hline Th & (a) & & & \\
\hline $\mathrm{Ti}$ & 0.003 & 0.003 & 0.002 & 0.003 \\
\hline $\mathrm{U}$ & 0.052 & 0.037 & 0.038 & 0.084 \\
\hline $\mathrm{pH}$ & 9.81 & 9.81 & 9.74 & 9.95 \\
\hline
\end{tabular}

(a) Absence of data indicates less than analytical detection limit. 


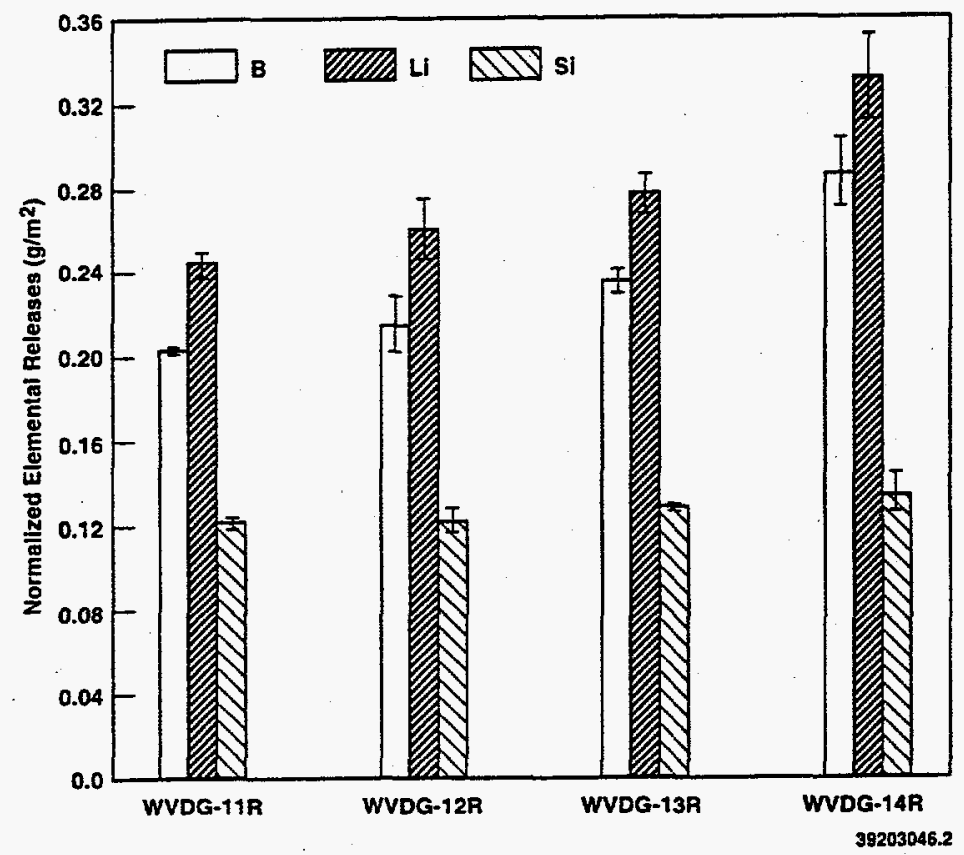

Figure 4.2. Normalized Elemental Mass Loss of B, Li, and Si for Redox Set of FY 1987 Compositional Variation Glasses (4 Glasses, WVDG-11R to WVDG-14R). (Error bars are \pm 1 standard deviation taking into account variation in leachate concentrations only.)

\subsubsection{Second Set of Compositional Variation Glasses: 16 Glasses, FY 1987}

The averaged normalized elemental releases are listed in Table 4.3. The normalized releases for B, $\mathrm{Li}$, and $\mathrm{Si}$ are displayed in Figure 4.3 for glasses WVDG-15 to WVDG-22 and Figure 4.4 for WVDG-23 to WVDG-30. Based on normalized release, the least chemically durable glasses were WVDG-17, WVDG-27, and WVDG-15 and the most chemically durable was WVDG-20. These same results were observed in the testing by Reimus et al. (1988).

Consistently, the least chemically durable glasses (WVDG-17, WVDG-27, and WVDG-15) had the highest amount of alkali oxides $\left(\mathrm{Na}_{2} \mathrm{O}, \mathrm{K}_{2} \mathrm{O}\right.$, and $\left.\mathrm{Li}_{2} \mathrm{O}\right)$ at $14.54 \mathrm{wt} \%$ to $14.98 \mathrm{wt} \%$, and the most chemically durable glass (WVDG-20) had the least amount of alkali oxides at $12.90 \mathrm{wt} \%$. The reference glass, WVCM-50 (WVDG-30), had an intermediate amount of alkali oxides, $13.54 \mathrm{wt} \%$. 


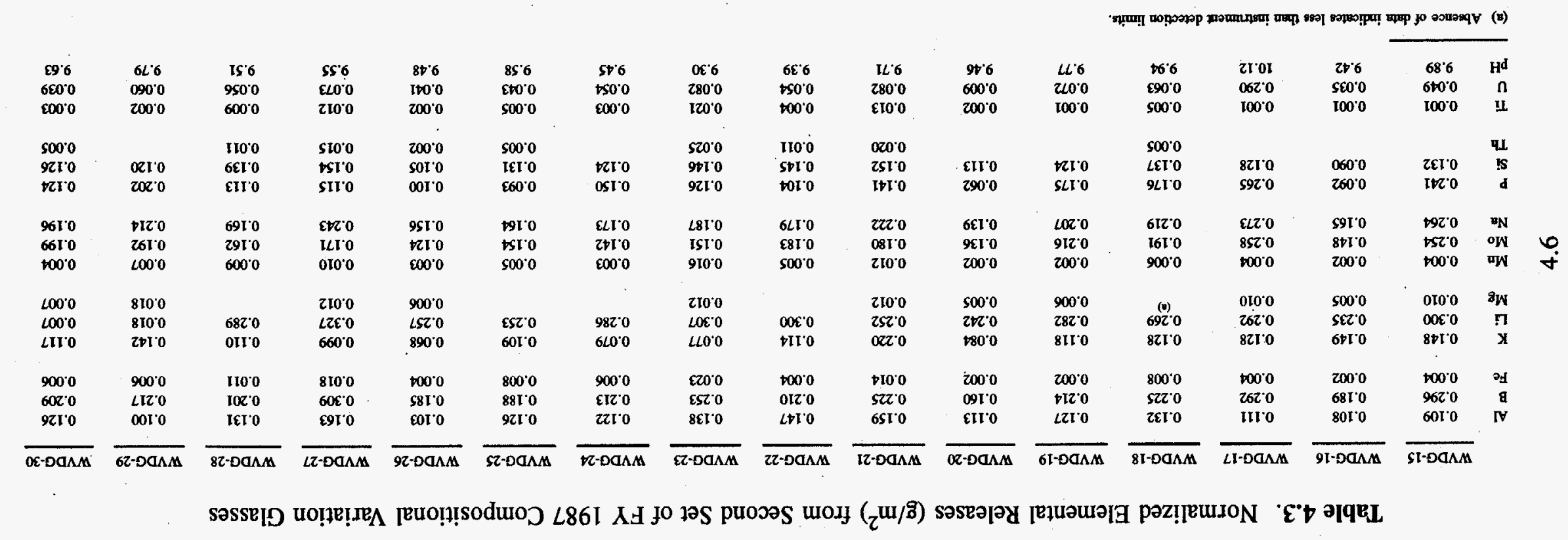




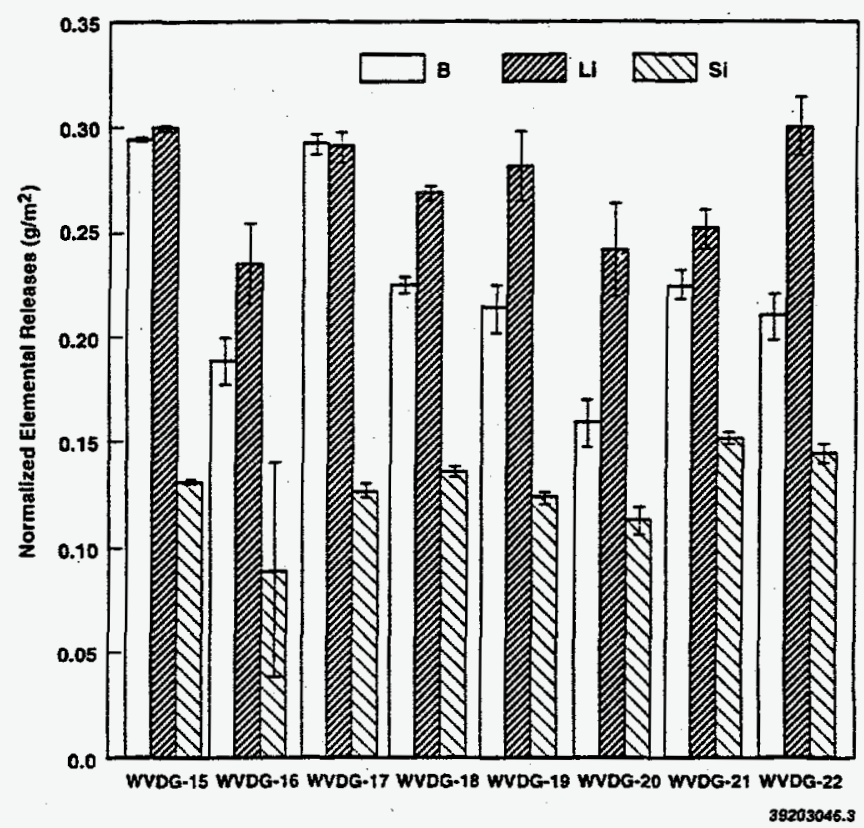

Figure 4.3. Normalized Elemental Mass Loss of B, Li, and Si for Second Set of FY 1987 Compositional Variation Glasses (8 Glasses, WVDG-15 to WVDG-22). (Error bars are \pm 1 standard deviation taking into account variation in leachate concentrations only.)

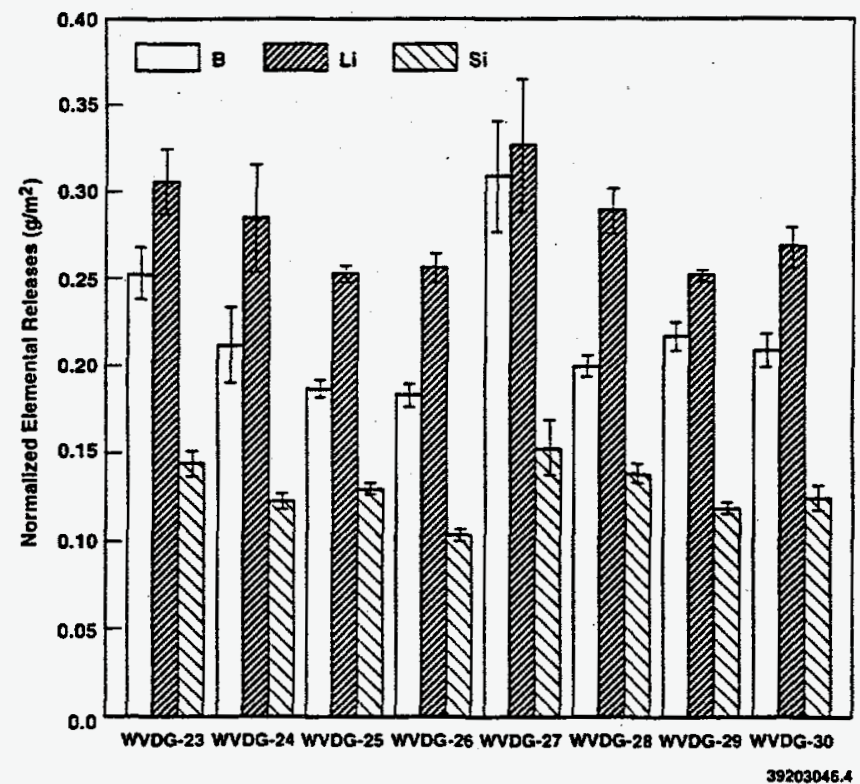

Figure 4.4. Normalized Elemental Mass Loss of B, Li, and Si for Second Set of FY 1987 Compositional Variation Glasses (8 Glasses, WVDG-23 to WVDG-30). (Error bars are \pm 1 standard deviation taking into account variation in leachate concentrations only.) 


\subsubsection{Compositional Variation Glasses: 16 Glasses, FY 1988}

The normalized elemental releases are listed in Table 4.4. Normalized releases for $\mathrm{B}, \mathrm{Li}$, and $\mathrm{Si}$ are displayed in Figure 4.5 for WVDG-33 to WVDG-40 and Figure 4.6 for WVDG-41 to WVDG-48. Based on normalized B-release values, the least chemically durable glasses in this group were WVDG-35 and WVDG-42, and the most chemically durable glass was WVDG-48. Again the least chemically durable glasses (WVDG-35 and WVDG-42) had the highest amount of alkali oxides at $18.19 \%$ and $17.01 \%$, respectively, and the most chemically durable glass (WVDG-48) had the least amount of alkali oxides at $13.13 \%$. The reference glass, WV-8801, (WVDG-33) contained an intermediate amount of alkali oxides at $16.86 \%$.

\subsubsection{Comparisons of All Glasses}

The leaching results that were obtained during this PCT and previous MCC-3 testing (Reimus et al. 1988) of the 44 glasses are presented in Figures 4.7 through 4.10. Boron, $\mathrm{Li}$, and $\mathrm{Si}$ releases are shown in Figure 4.7, 4.8, and 4.9, respectively. These results are in agreement with each other when these PCT and previous MCC-3 tests are compared. However, U-release results (Figure 4.10) from the two tests do not agree. Results from these PCT tests are about $22 \%$ higher than those from Reimus et al. (1988).

\subsection{Duplicate Tests}

Included in the PCT were three glasses with the same target composition: WVDG-31B and -31C were duplicates of WVDG-30. All three glasses were identical in composition to the Catholic University of America (CUA) reference glass WVCM-50. Their analyzed compositions can be compared in Table 3.2. The normalized releases of $\mathrm{B}, \mathrm{Li}$, and $\mathrm{Si}$ are listed in Table 4.5. The three glasses show nearly identical durability, in the plotted $\mathrm{B}, \mathrm{Li}$, and $\mathrm{Si}$ results in Figure 4.11.

\subsection{Arm-1 Reference Glass Tests}

Six samples of reference glass ARM-1 were included in the test matrix. The averaged normalized releases are listed in Table 4.6 as are the averaged normalized releases from a different PCT of ARM-1 that was tested along with WVSG-1 (Olson et al. 1990). ${ }^{(a)}$ Comparison shows that the 1992 testing yielded concentrations of the major elements in the leachate that were much lower (as little as half as much) than those from the 1990 PCT of WVSG-1. This would be expected, since the crushed glass was not washed for the earlier tests, and a large amount of -200 mesh glass was expected to be present in those specimens.

(a) Olson, K. M., M. L. Elliott, J. W. Shade, and H. D. Smith. 1990. "Fabrication, Characterization, and Evaluation of West Valley Sludge Glass-1 (WVSG-1), a Fully Radioactive Glass Made with High-Level Waste from the West Valley Demonstration Project." Letter report prepared by Pacific Northwest Laboratory, Richland, Washington. 
Table 4.4. Normalized Elemental Releases $\left(\mathrm{g} / \mathrm{m}^{2}\right)$ from FY 1988 Composition Variation Glasses

\begin{tabular}{|c|c|c|c|c|c|c|c|c|c|c|c|c|c|c|c|c|}
\hline & WVDG-33 & WVDO-34 & WVDG-35 & WVDG-36 & WVDG-37 & WVDG-38 & WVDG-39 & WVDG-40 & WVDG-41 & WVDG-42 & WVDG-43 & WVDG-44 & WVDG-45 & WVDG-46 & WVDG-47 & WVDG-48 \\
\hline Al & 0.116 & 0.122 & 0.182 & 0.111 & 0.152 & 0.134 & 0.122 & 0.095 & 0.127 & 0.086 & 0.137 & 0.146 & 0.160 & 0.110 & 0.122 & 0.126 \\
\hline B & 0.247 & 0.417 & 0.400 & 0.244 & 0.231 & 0.197 & 0.271 & 0.305 & 0.314 & 0.380 & 0.208 & 0.357 & 0.260 & 0.372 & 0.224 & 0.179 \\
\hline $\mathrm{Fe}$ & 0.009 & 0.004 & 0.013 & 0.003 & 0.011 & 0.007 & 0.008 & 0.004 & 0.011 & 0.009 & 0.038 & 0.007 & 0.009 & 0.010 & 0.029 & 0.003 \\
\hline $\mathbf{k}$ & 0.138 & 0.175 & 0.225 & 0.157 & 0.140 & 0.131 & 0.169 & 0.188 & 0.173 & 0.223 & 0.096 & 0.161 & 0.167 & 0.165 & 0.124 & 0.118 \\
\hline $\mathrm{Li}$ & 0.263 & 0.388 & 0.394 & 0.251 & 0.267 & 0.240 & 0.249 & 0.305 & 0.299 & 0.355 & 0.257 & 0.358 & 0.265 & 0.317 & 0.233 & 0.206 \\
\hline $\overrightarrow{\mathrm{M}}_{\mathbf{g}}$ & 0.017 & (a) & 0.018 & & & & 0.018 & 0.012 & & 0.018 & 0.013 & & & 0.023 & 0.019 & 0.004 \\
\hline $\mathrm{Mn}$ & 0.008 & 0.004 & 0.009 & 0.004 & 0.008 & 0.004 & 0.009 & 0.004 & 0.008 & 0.008 & 0.021 & 0.006 & 0.008 & 0.010 & 0.022 & 0.004 \\
\hline Mo & 0.270 & 0.395 & 0.349 & 0.280 & 0.318 & 0.256 & 0.187 & 0.314 & 0.198 & 0.555 & 0.131 & 0.230 & 0.381 & 0.232 & 0.180 & 0.174 \\
\hline $\mathbf{N a}$ & 0.245 & 0.363 & 0.399 & 0.164 & 0.267 & 0.197 & 0.247 & 0.289 & 0.369 & 0.364 & 0.138 & 0.331 & 0.300 & 0.299 & 0.156 & 0.129 \\
\hline $\mathbf{p}$ & 0.206 & 0.253 & 0.287 & 0.125 & 0.193 & $0.146^{\circ}$ & 0.206 & 0.224 & 0.305 & 0.351 & 0.096 & 0.173 & 0.269 & 0.196 & 0.143 & 0.066 \\
\hline $\mathrm{si}$ & 0.138 & 0.168 & 0.185 & 0.134 & 0.148 & 0.133 & 0.128 & 0.154 & 0.161 & 0.173 & 0.138 & 0.152 & 0.155 & 0.145 & 0.140 & 0.123 \\
\hline Th & 0.003 & & & 0.003 & 0.007 & 0.005 & 0.004 & & 0.004 & & 0.024 & 0.004 & 0.007 & 0.005 & 0.026 & \\
\hline Ti & 0.005 & 0.003 & 0.003 & 0.003 & 0.009 & 0.006 & 0.002 & 0.001 & 0.003 & 0.003 & 0.023 & 0.004 & 0.008 & 0.004 & 0.022 & 0.003 \\
\hline $\mathrm{u}$ & 0.068 & 0.037 & 0.079 & 0.042 & 0.033 & 0.076 & 0.054 & 0.074 & 0.085 & 0.021 & 0.066 & 0.066 & 0.056 & 0.075 & 0.110 & 0.006 \\
\hline $\mathrm{pH}$ & 10.17 & 10.14 & 10.83 & 9.68 & 10.38 & 10.23 & 9.90 & 10.32 & 10.52 & 10.44 & 9.35 & 10.29 & 10.57 & 10.01 & 9.30 & 9.32 \\
\hline
\end{tabular}

(a) Absence of data indicater less than analytical detection limit. 


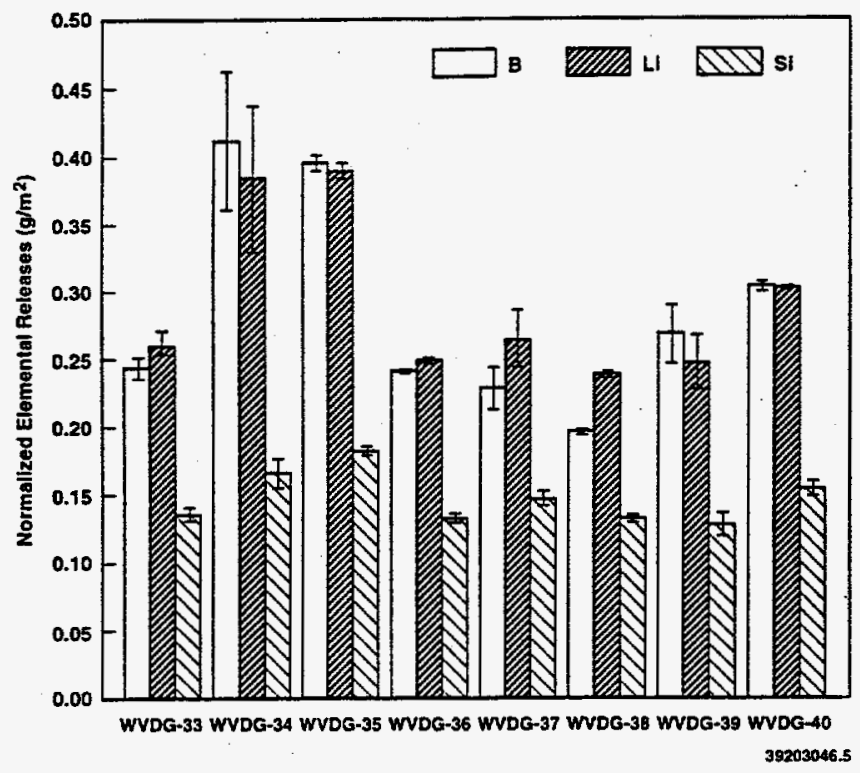

Figure 4.5. Normalized Elemental Mass Loss of B, Li, and Si for Set of FY 1988 Compositional Variation Glasses (8 Glasses, WVDG-33 to WVDG-40). (Error bars are \pm 1 standard deviation taking into account variation in leachate concentrations only.)

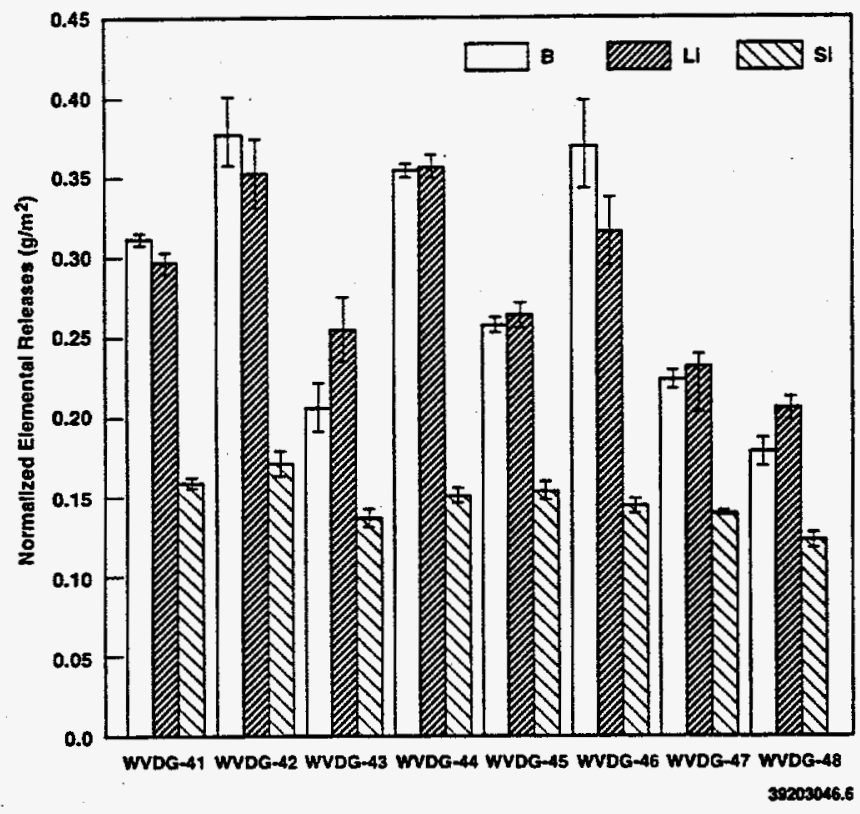

Figure 4.6. Normalized Elemental Mass Loss of B, Li, and Si for Set of FY 1988 Compositional Variation Glasses (8 Glasses, WVDG-41 to WVDG-48) (Error bars are \pm 1 standard deviation taking into account variation in leachate concentrations only.) 


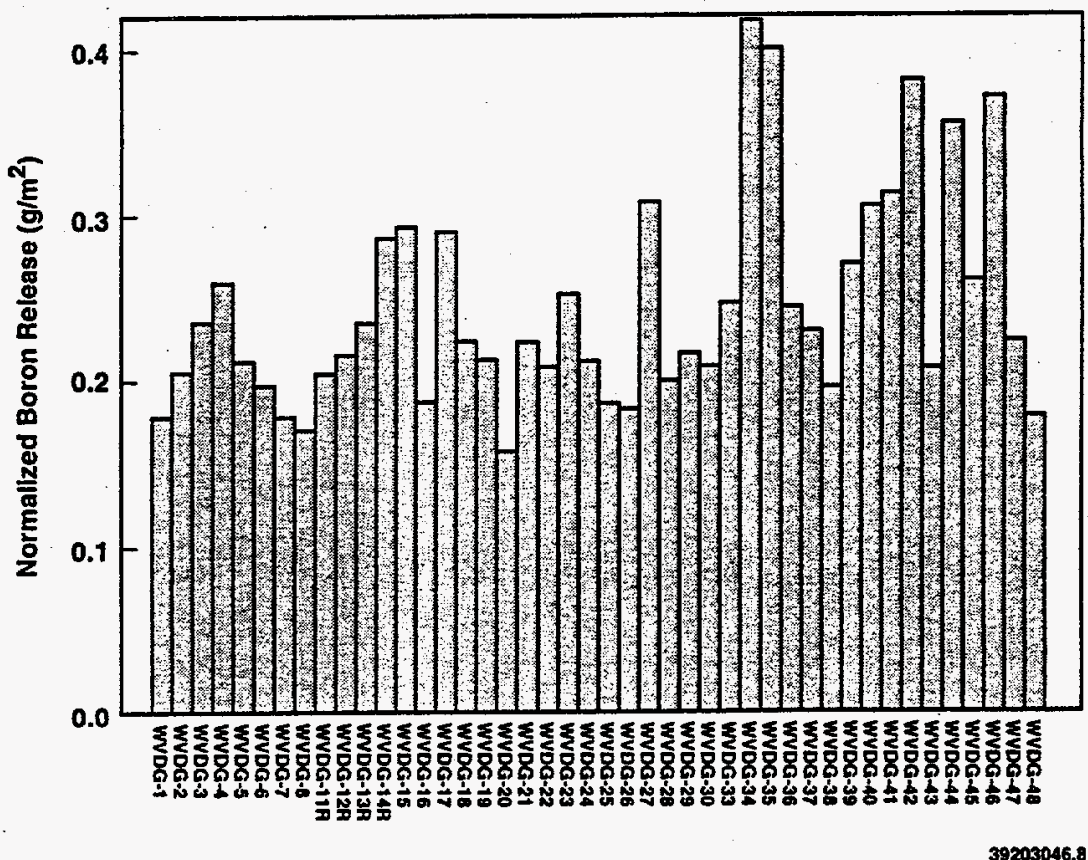

Figure 4.7a. Normalized Elemental Mass Loss of B from all 44 Test Glasses, Results from PCT Tests

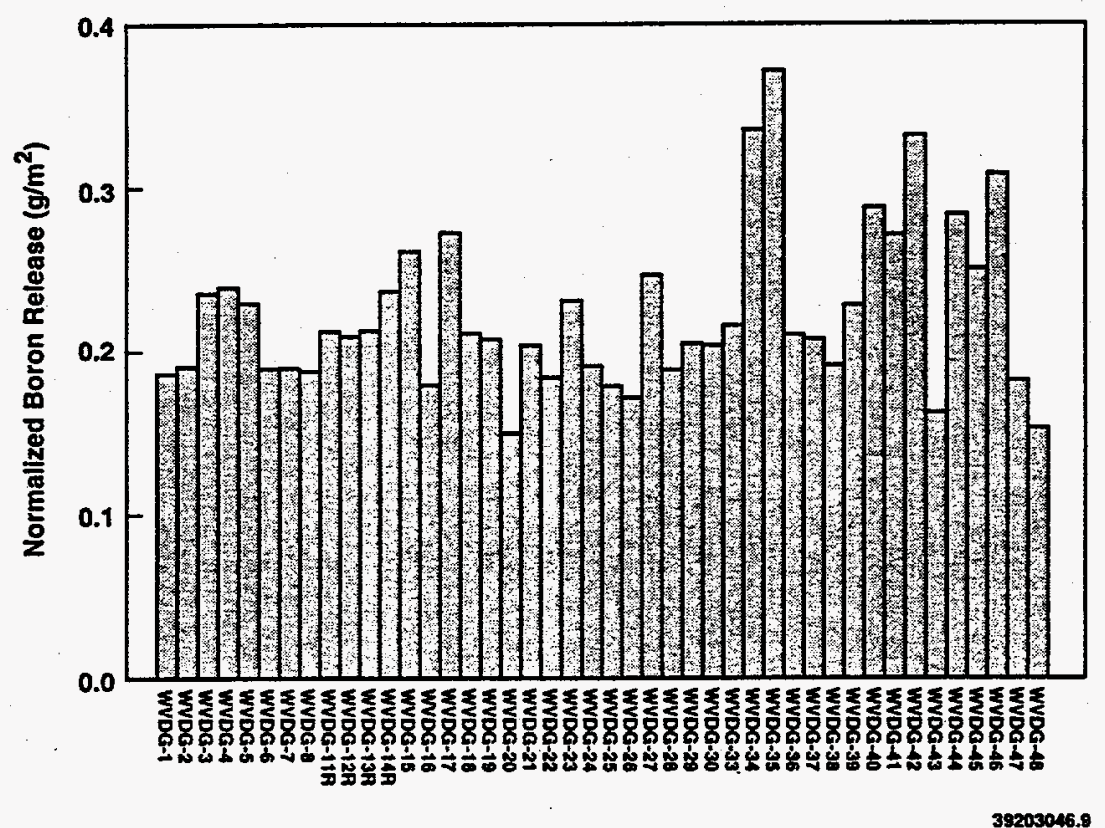

Figure 4.7b. Normalized Elemental Mass Loss of B from all 44 Test Glasses, Results from Modified MCC-3 Testing Performed by Reimus et al. (1988) 

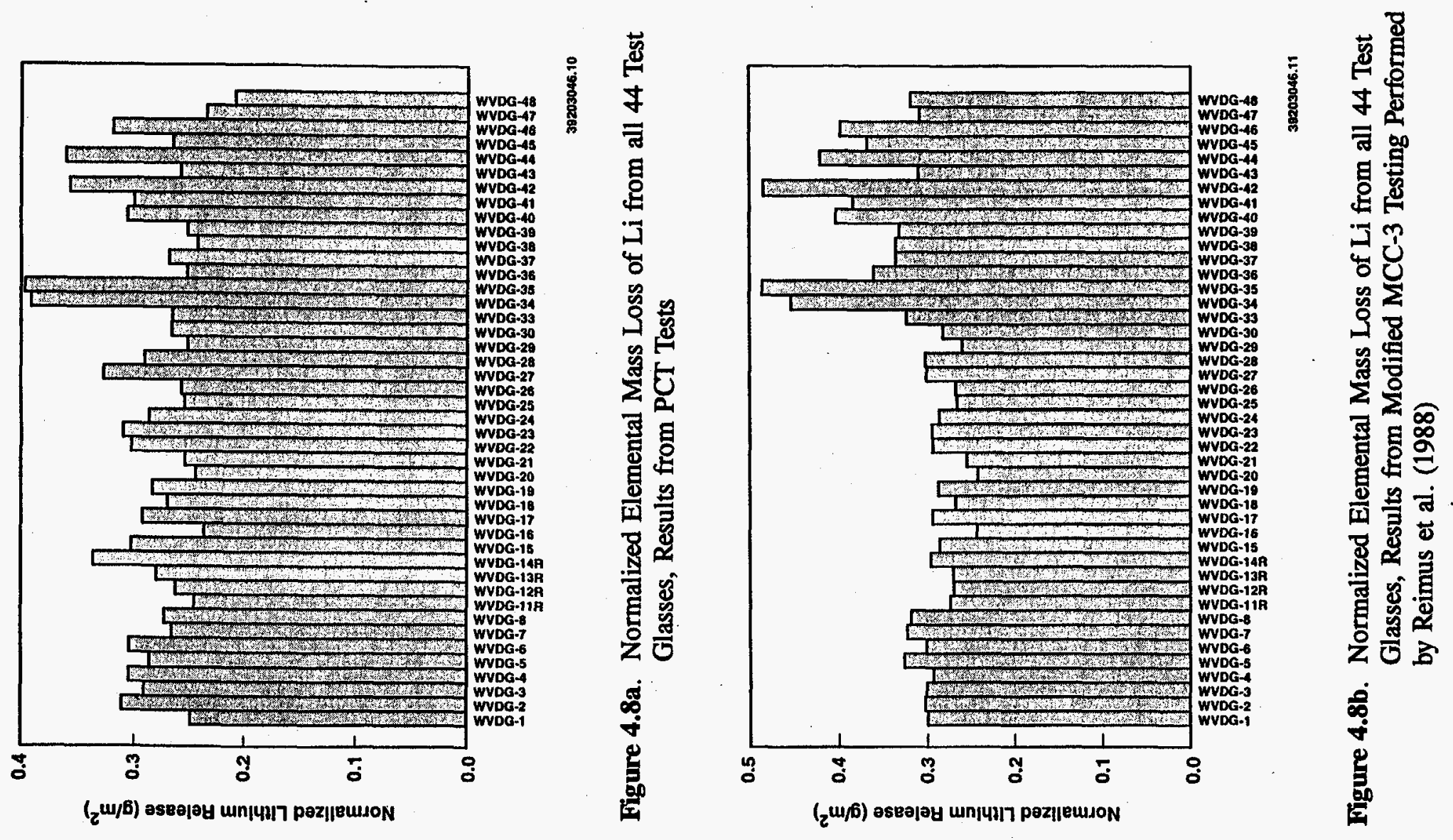

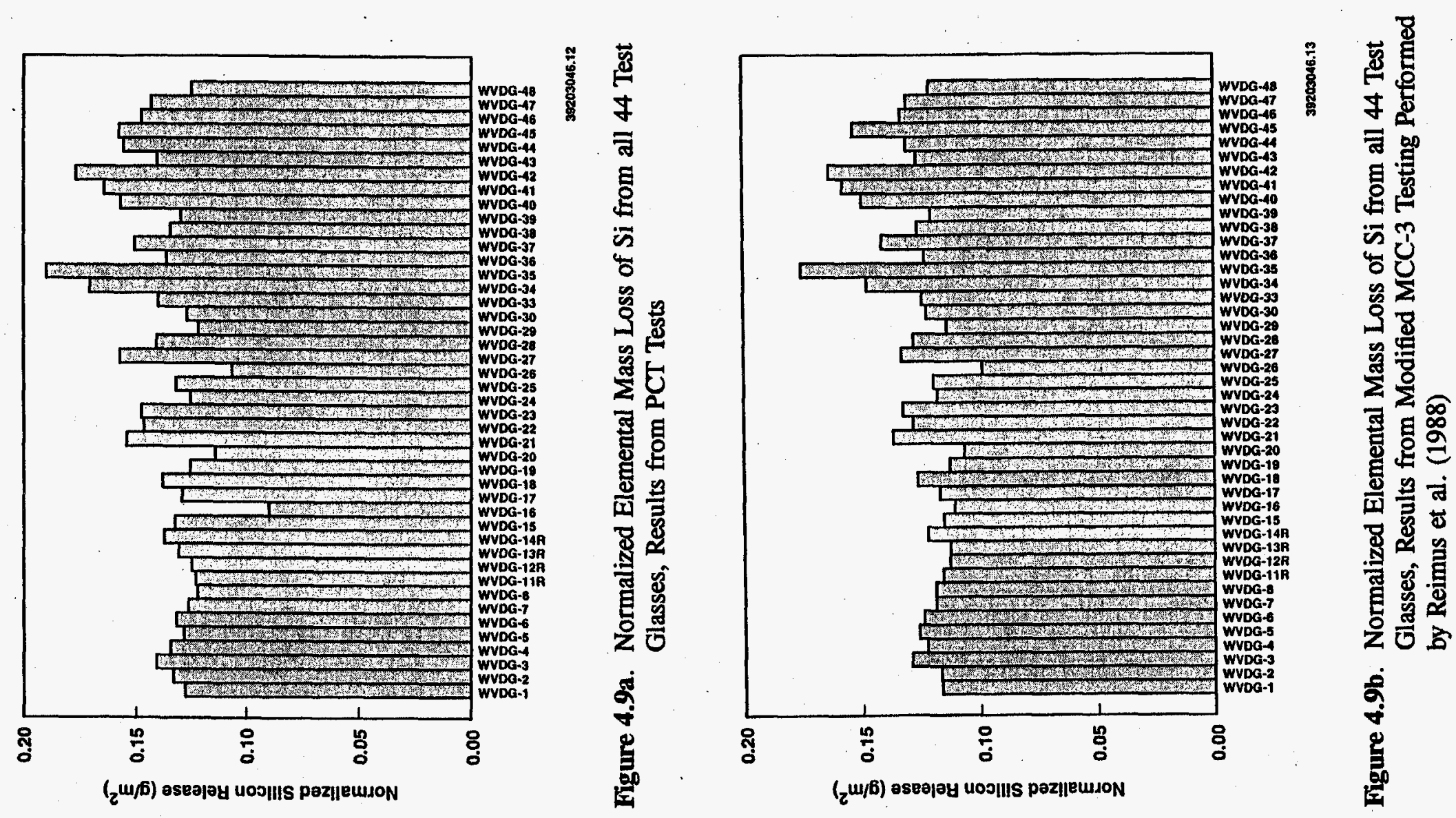

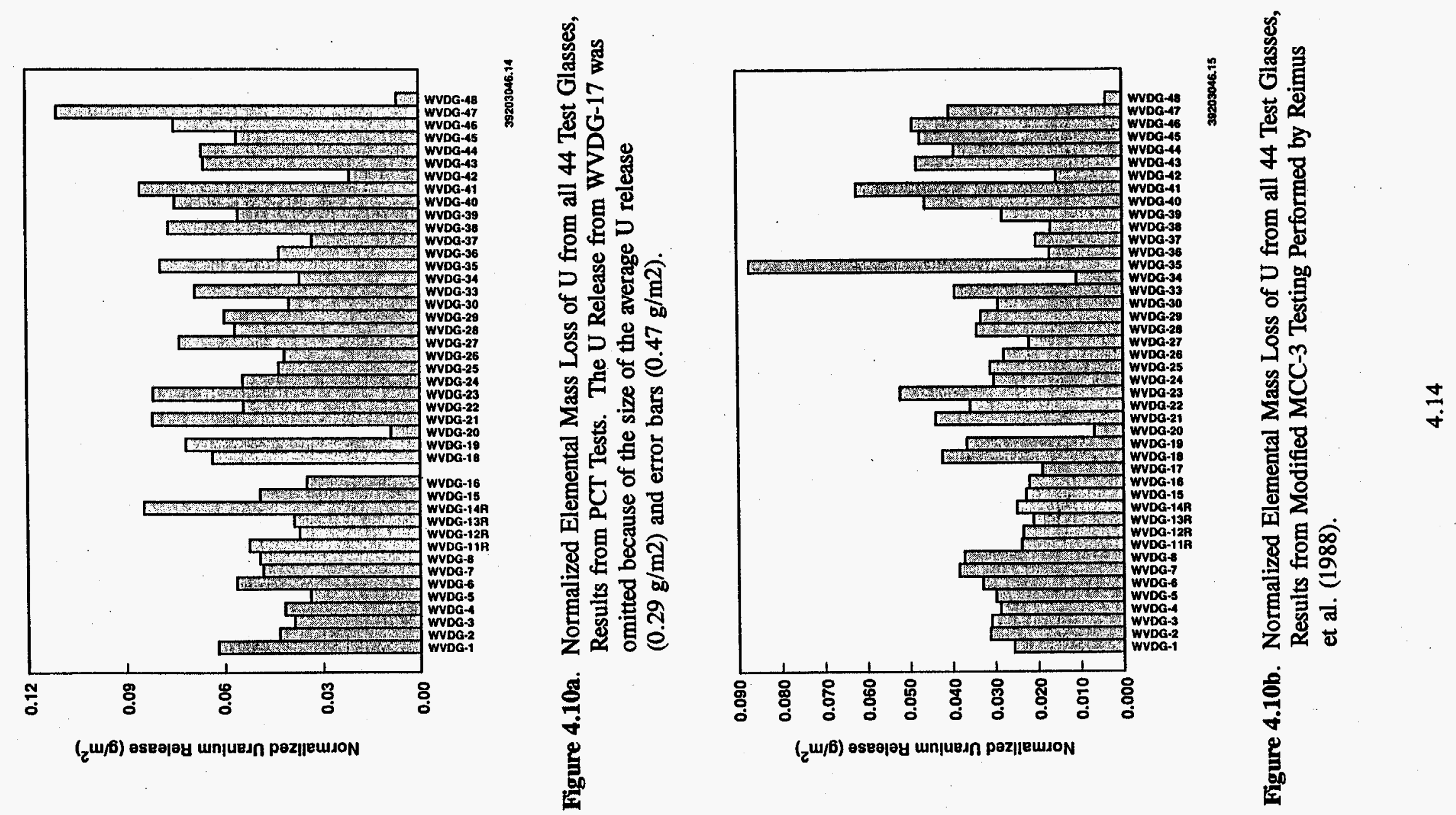
Table 4.5. Normalized Elemental $\left(\mathrm{g} / \mathrm{m}^{2}\right)$ Releases from Three Glasses Having Target Composition of WVCM-50

\begin{tabular}{|c|c|c|c|c|c|c|}
\hline & WVDG-31B & WVDG-31C & WVDG-30 & Mean & $\begin{array}{l}\text { Standard } \\
\text { Deviation }\end{array}$ & $\begin{array}{l}\text { Relative Standard } \\
\text { Deviation, \%(b) }\end{array}$ \\
\hline $\mathrm{Al}$ & 0.080 & 0.111 & 0.126 & 0.106 & 0.023 & 22.2 \\
\hline $\mathbf{B}$ & 0.151 & 0.221 & 0.209 & 0.194 & 0.037 & 19.3 \\
\hline $\mathrm{Fe}$ & 0.004 & 0.005 & 0.006 & 0.005 & 0.001 & 20.0 \\
\hline K & 0.082 & 0.114 & 0.117 & 0.104 & 0.019 & 18.6 \\
\hline $\mathrm{Li}$ & 0.180 & 0.263 & 0.267 & 0.237 & 0.049 & 20.8 \\
\hline Mg & 0.010 & 0.006 & 0.007 & 0.008 & 0.002 & 27.2 \\
\hline $\mathbf{M n}$ & 0.005 & 0.005 & 0.004 & 0.005 & 0.001 & 12.4 \\
\hline Mo & (a) & 0.199 & & 0.199 & & \\
\hline $\mathrm{Na}$ & 0.145 & 0.211 & 0.196 & 0.184 & 0.035 & 18.8 \\
\hline $\mathbf{P}$ & 0.123 & 0.160 & 0.124 & 0.136 & 0.021 & 15.5 \\
\hline $\mathrm{Si}$ & 0.091 & 0.129 & 0.126 & 0.115 & 0.021 & 18.3 \\
\hline Th & 0.003 & & 0.005 & 0.004 & 0.001 & 35.4 \\
\hline $\mathrm{Ti}$ & 0.003 & 0.003 & 0.003 & 0.003 & 0.000 & 0.0 \\
\hline $\mathrm{U}$ & 0.040 & 0.058 & 0.039 & 0.046 & 0.011 & 23.4 \\
\hline $\mathrm{pH}$ & 9.783 & 9.873 & 9.630 & 9.76 & 0.123 & 1.26 \\
\hline
\end{tabular}

(a) Absence of data indicates less than analytical detection limits.

(b) Percent relative standard deviation computed before rounding the means and standard deviation to three decimal places. 


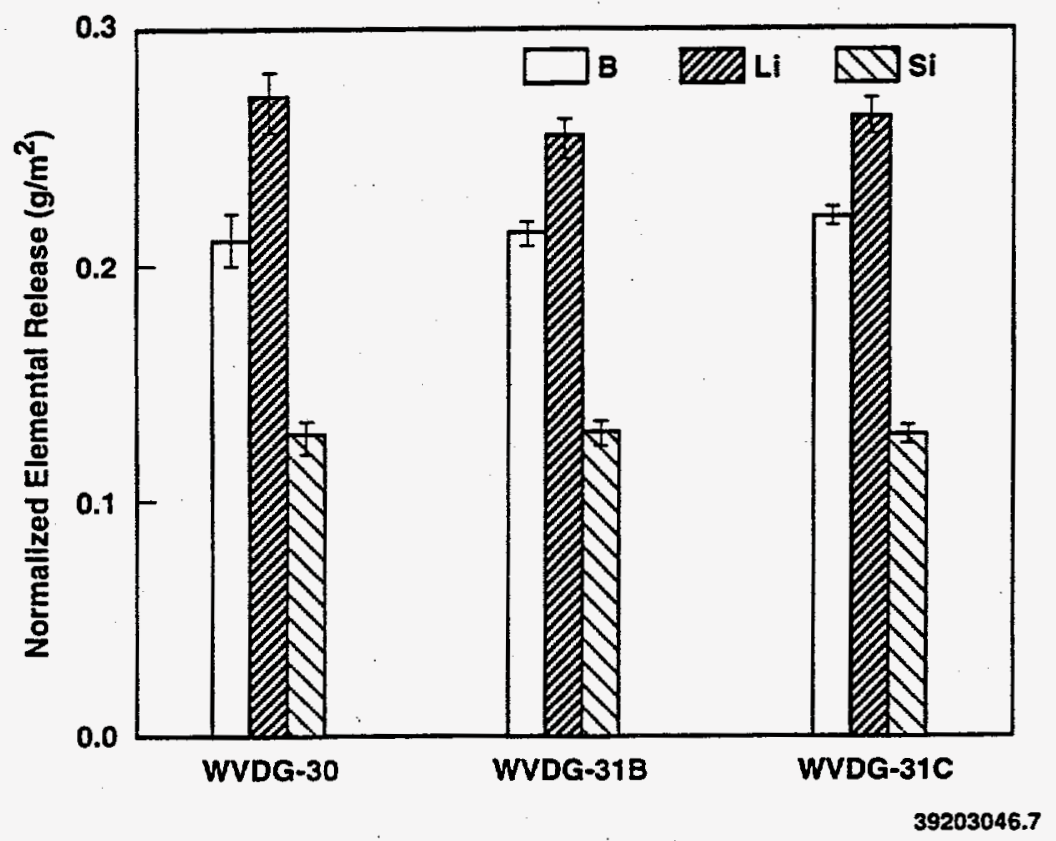

Figure 4.11. Normalized Release of $\mathrm{B}, \mathrm{Li}$, and $\mathrm{Si}$ from Nearly Duplicate Glasses, WVDG-30, WVDG-31B, and WVDG-31C. (Error bars are \pm standard deviation taking into account variation in leachate concentrations only.) 
Table 4.6. Normalized Elemental Releases from ARM-1 Reference Tests Accompanying West Valley PCT Tests

\begin{tabular}{lcc} 
& $\begin{array}{c}\text { ARM-1 with Compositional } \\
\text { Variability Glasses } \\
\text { (Average of 6) }\end{array}$ & $\begin{array}{c}\text { ARM-1 with } \\
\text { WVSG-1 Testing (1990) } \\
\text { (Average of 8) }^{(a)}\end{array}$ \\
\cline { 2 - 3 } $\mathrm{Al}$ & 0.074 & 0.048 \\
$\mathrm{~B}$ & 0.249 & 0.425 \\
$\mathrm{Ca}$ & 0.005 & 0.004 \\
$\mathrm{Li}$ & 0.297 & 0.481 \\
$\mathrm{Mo}$ & 0.255 & 0.411 \\
$\mathrm{Na}$ & 0.260 & 0.397 \\
$\mathrm{P}$ & 0.155 & \\
$\mathrm{Si}$ & 0.140 & 0.228 \\
$\mathrm{Sr}$ & 0.003 & 0.175 \\
$\mathrm{Ti}$ & 0.001 & 0.002 \\
$\mathrm{Zn}$ & 0.002 & 0.001 \\
$\mathrm{Zr}$ & 0.001 & 0.002 \\
$\mathrm{pH}$ & 10.36 & 0.001 \\
$\mathrm{pr}$ & & 10.35 \\
\hline
\end{tabular}

(a) ARM-1 was not washed. 


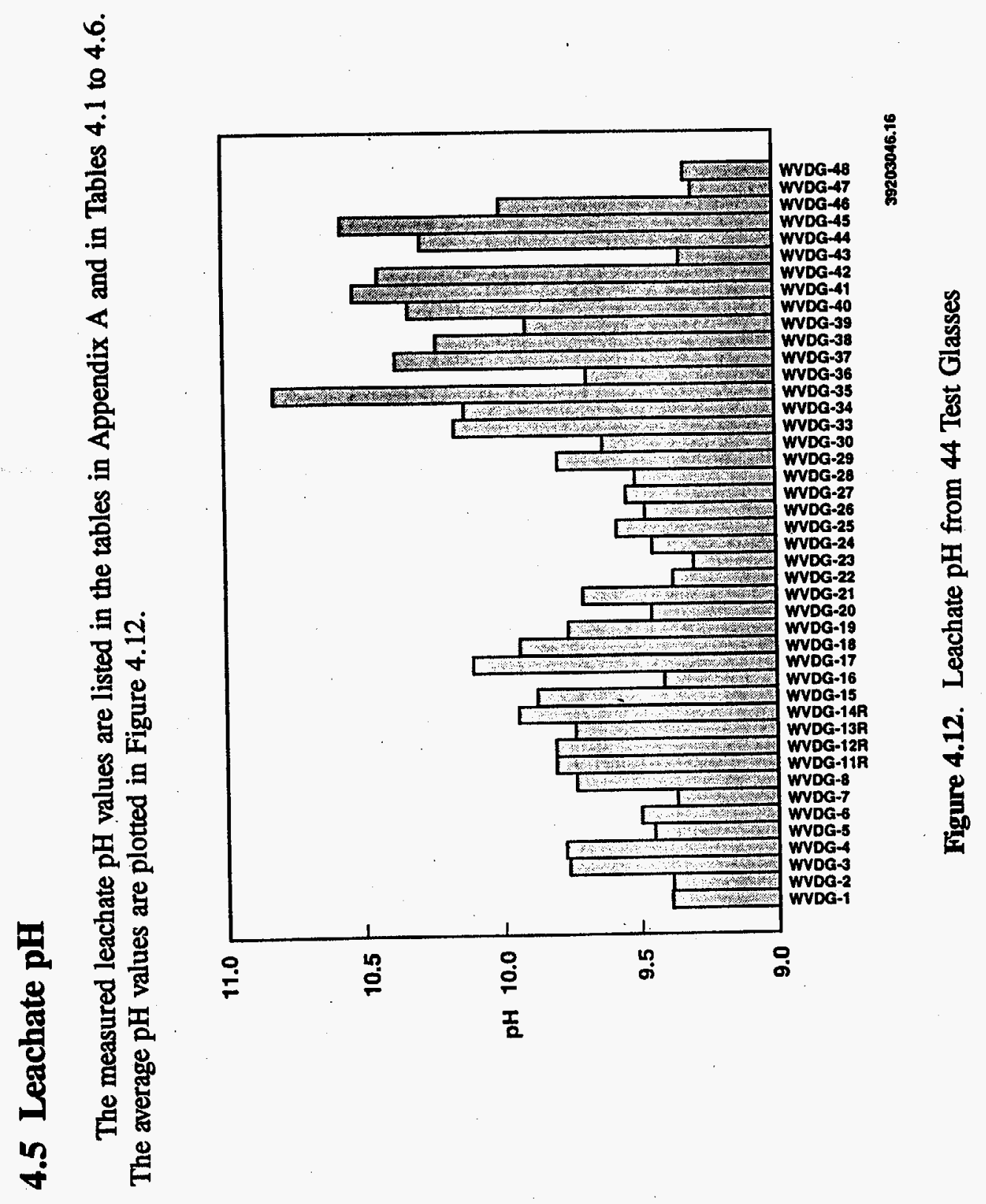




\subsection{References}

Mellinger, G. B., and J. L. Daniel. 1984. Approved Reference and Testing Materials for Use in Nuclear Waste Management Research and Development Programs. PNL-4955-2, Pacific Northwest Laboratory, Richland, Washington.

Reimus, M.A.H., G. F. Piepel, G. B. Mellinger, and L. R. Bunnell. 1988. Wést Valley Glass Product Qualification Durability Studies, FY 1987-1988: Effects of Composition, Redox State, Thermal History, and Groundwater. PNL-6723, Pacific Northwest Laboratory, Richland, Washington. 


\section{Appendix A}

\section{Product Consistency Test Information and Results}




\section{Appendix A}

\section{Product Consistency Test Information and Results}

The PCT described in this report was performed under MCC-TP-19 (Materials Characterization Center, Technical Procedure 19) and Test Instruction 1. The laboratory record book (LRB) used for this work was BNW 51741. The making of the West Valley doped glasses (WVDG glasses) was described in LRB BNW 51398.

A run order number is listed for each sample in Appendix A; these numbers were assigned by MCC personnel. The first number indicates the order in which the test was assembled; the order was chosen randomly by computer. The second number indicates the test series $(1,2$, or 3$)$. Since artificial numbers were created for ARM-1 (WVDG-49 and WVDG-50) and blanks (WVDG-51 and WVDG-52), the numbers were also used for the blind numbers when the leachate samples were sent for analysis.

An analytical number is also listed for each sample. These numbers were assigned by the analytical laboratory and should be included in any inquiries made to that laboratory. The order of analysis was the same random order used in assembling the tests. 
Table A.1. Test Information and Leachate ICP and XRF Results for First Series of PCT Tests of West Valley Compositional Variability Glasses

Days of Test
Date Test Began
Date Test Ended
Specimen Wgt., g
Leachant Volume, mL
SA/V
Specimen Mesh Size
Initial pH
Final pH
Total Init. Wgt., g.
Total Final Weight, $g$
Run Order and Blind No.
Date of Analysis
Analytical Number
$\quad$ Elements

\begin{tabular}{|c|c|c|c|c|c|}
\hline WVDG-1 & WVDG-2 & WVDG-3 & WVDG-4 & WVDG-5 & WVDG-6 \\
\hline 7 & 7 & 7 & 7 & 7 & 7 \\
\hline 29-OCT-90 & $30-$ OCT-90 & $29-0 C T-90$ & 29-OCT-90 & $30-$ OCT-90 & $30-O C T-90$ \\
\hline 05-NOV-90 & 06-NOV-90 & 05-NOV-90 & 05-NOV-90 & 06-NOV-90 & 06-NOV-90 \\
\hline 2.0841 & 3.0945 & 3.1205 & 3.1660 & 3.0538 & 3.0465 \\
\hline 20.84 & 30.94 & 31.21 & 31.65 & 30.55 & 30.46 \\
\hline 2000.1 & 2000.3 & 1999.7 & 2000.6 & 1999.2 & 2000.3 \\
\hline$-100+200$ & $-100+200$ & $-100+200$ & $-100+200$ & $-100+200$ & $-100+200$ \\
\hline 6.16 & 6.16 & 6.16 & 6.16 & 6.16 & 6.16 \\
\hline 9.31 & 9.32 & 9.68 & 9.61 & 9.38 & 9.55 \\
\hline 98.46 & 114.05 & 112.17 & 111.21 & 111.71 & 113.20 \\
\hline 98.15 & 112.24 & 111.12 & 109.66 & 111.25 & 110.41 \\
\hline $19-1$ & $36-1$ & $3-1$ & $10-1$ & $28-1$ & $49-1$ \\
\hline $11-\mathrm{DEC}-90$ & 11-DEC-90 & 11-DEC-90 & 11-DEC-90 & $11-D E C-90$ & 11-DEC-90 \\
\hline $90-7901$ & $90-7918$ & $90-7885$ & $90-7892$ & $90-7910$ & $90-7931$ \\
\hline
\end{tabular}

Al $(0.05)^{(a)}$

B $(0.01)$

Ba $(0.005)$

$\mathrm{Ca}(0.02)$

Cd (0.005)

$\mathrm{Ce}(0.05)$

Cr $(0.02)$

$\mathrm{Cu}(0.005)$

$\mathrm{Fe}(0.01)$

K $(0.3)$

La $(0.01)$

Li (0.005)

$\mathrm{Mg}(0.06)$

$\mathrm{Mn}(0.005)$

Mo (0.02)

$\mathrm{Na}(0.02)$

Nd $(0.03)$

Ni (0.03)

$P(0.1)$

Ru (0.05)

$\mathrm{Sb}(0.05)$

Si $(0.02)$

$\mathrm{Sr}(0.003)$

Th (0.15)

Ti (0.005)

$\mathrm{U}(0.015)$

$\mathrm{V}(0.01)$

$Y(0.01)$

$\mathrm{Zn}(0.02)$

$\operatorname{Zr}(0.01)$

Leachate Analyzed Concentration, $\mathrm{mg} / \mathrm{L}$

\begin{tabular}{llllll}
\hline & \multicolumn{5}{c}{ Leachate Analyzed Concentration, mg/l } \\
\hline 10.1 & 10.5 & 7.19 & 9.87 & 7.20 & 10.5 \\
13.6 & 15.5 & 13.1 & 19.7 & 17.5 & 15.5 \\
0.006 & 0.002 & 0.003 & 0.001 & 0.002 & 0.001 \\
0.109 & 0.041 & 0.075 & 0.032 & 0.041 & 0.036 \\
$-0.001^{(b)}$ & -0.001 & -0.000 & -0.001 & 0.001 & -0.000 \\
0.011 & 0.012 & -0.003 & 0.006 & 0.028 & 0.031 \\
0.012 & 0.003 & 0.013 & 0.004 & 0.003 & -0.001 \\
0.000 & 0.004 & -0.001 & -0.002 & 0.001 & -0.001 \\
1.71 & 0.700 & 0.829 & 0.635 & 0.488 & 0.634 \\
1.65 & 1.80 & 2.71 & 1.57 & 2.96 & 2.26 \\
0.008 & 0.001 & 0.002 & 0.001 & 0.005 & 0.004 \\
4.03 & 5.01 & 6.23 & 5.02 & 4.87 & 5.01 \\
0.126 & 0.076 & 0.295 & 0.121 & 0.072 & 0.045 \\
0.139 & 0.065 & 0.121 & 0.071 & 0.047 & 0.037 \\
0.023 & 0.023 & 0.046 & 0.033 & 0.030 & 0.022 \\
21.2 & 24.3 & 33.4 & 46.6 & 27.9 & 23.4 \\
0.027 & 0.003 & 0.007 & 0.003 & 0.022 & 0.015 \\
0.027 & 0.016 & 0.024 & 0.019 & 0.017 & 0.010 \\
1.92 & 2.46 & 4.17 & 4.23 & 3.15 & 3.26 \\
0.005 & -0.002 & 0.000 & -0.005 & 0.011 & 0.005 \\
0.018 & -0.000 & 0.028 & 0.019 & 0.019 & 0.002 \\
49.8 & 54.7 & 57.5 & 52.1 & 55.1 & 54.3 \\
0.003 & 0.001 & 0.001 & 0.001 & 0.001 & 0.001 \\
0.455 & 0.160 & 0.081 & 0.078 & 0.105 & 0.097 \\
0.093 & 0.037 & 0.034 & 0.023 & 0.023 & 0.029 \\
0.528 & 0.401 & 0.421 & 0.403 & 0.333 & 0.856 \\
0.005 & 0.001 & 0.002 & 0.002 & 0.005 & 0.002 \\
0.003 & 0.001 & 0.001 & 0.001 & 0.001 & 0.001 \\
-0.010 & -0.014 & -0.012 & -0.016 & -0.014 & -0.016 \\
0.006 & 0.008 & 0.000 & 0.000 & 0.001 & 0.001 \\
& & & & &
\end{tabular}

(a) Numbers in parentheses are instrument detection limits.

(b) Negative numbers are the result of random variation at low concentrations. 
Table A.1. (contd)

\begin{tabular}{|c|c|c|c|c|c|c|}
\hline & WVDG-7 & WVDG-8 & WVDG-11R & WVDG-12R & WVDG-13R & WVDG-14R \\
\hline Days of Test & 7 & 7 & 7 & 7 & 7 & 7 \\
\hline Date Test Began & $30-$ OCT-90 & $30-$ OCT-90 & 29-ОCT-90 & $30-0 C T-90$ & $29-$ OCT-90 & 29-OCT-90 \\
\hline Date Test Ended & 06-NOV-90 & 06-NOV-90 & 05-NOV-90 & 06-NOV-90 & 05-NOV-90 & 05-NOV-90 \\
\hline Specimen Wgt., $\mathbf{g}$ & 3.0538 & 3.0712 & 3.0158 & 3.0326 & 3.0430 & 3.1316 \\
\hline Leachant Volume, $\mathrm{mL}$ & 30.54 & 30.71 & 30.16 & 30.32 & 30.44 & 31.30 \\
\hline SA/V & 2000.0 & 2000.1 & 1999.9 & 2000.4 & 1999.3 & 2001.0 \\
\hline Specimen Mesh Size & $-100+200$ & $-100+200$ & $-100+200$ & $-100+200$ & $-100+200$ & $-100+200$ \\
\hline Initial pH & 6.16 & 6.16 & 6.16 & 6.16 & 6.16 & 6.16 \\
\hline Final pH & 9.29 & 9.60 & 9.69 & 9.73 & 9.65 & 9.84 \\
\hline Total Init. Wgt., g & 113.60 & 111.70 & 111.53 & 113.22 & 113.12 & 113.45 \\
\hline Total Final Weight, $\mathrm{g}$ & 110.87 & 111.25 & 110.66 & 112.39 & 110.14 & 111.07 \\
\hline Run Onder and Blind No. & $34-1$ & $45-1$ & $15-1$ & $31-1$ & $21-1$ & $7-1$ \\
\hline Date of Analysis & 11-DEC-90 & $11-D E C-90$ & $11-D E C-90$ & $11-\mathrm{DEC}-90$ & 11-DEC-90 & 11-DEC-90 \\
\hline Analytical Number & $90-7916$ & $90-7927$ & $90-7897$ & $90-7913$ & $90-7903$ & $90-7889$ \\
\hline
\end{tabular}

\begin{tabular}{|c|c|c|c|c|c|c|}
\hline Elements & & & hate Ana & oncentrati & & \\
\hline $\mathrm{Al}(0.05)^{(\mathrm{a})}$ & 10.4 & 9.68 & 12.9 & 13.9 & 13.3 & 13.4 \\
\hline $\mathrm{B}(0.01)$ & 14.3 & 7.76 & 14.0 & 15.7 & 16.2 & 18.7 \\
\hline $\mathrm{Ba}(0.005)$ & 0.004 & 0.001 & 0.003 & 0.003 & 0.002 & 0.003 \\
\hline $\mathrm{Ca}(0.02)$ & 0.062 & 0.039 & 0.098 & 0.053 & 0.038 & 0.049 \\
\hline $\mathrm{Cd}(0.005)$ & 0.003 & $-0.002^{(b)}$ & -0.001 & 0.003 & 0.000 & 0.000 \\
\hline $\mathrm{Ce}(0.05)$ & 0.073 & 0.018 & 0.020 & 0.033 & 0.005 & 0.010 \\
\hline Cr $(0.02)$ & 0.011 & -0.001 & -0.002 & 0.002 & -0.000 & -0.000 \\
\hline $\mathrm{Cu}(0.005)$ & 0.007 & -0.002 & 0.000 & 0.001 & -0.001 & 0.002 \\
\hline $\mathrm{Fe}(0.01)$ & 0.816 & 0.317 & 0.501 & 1.02 & 0.683 & 0.920 \\
\hline $\mathrm{K}(0.3)$ & 4.88 & 2.41 & 5.94 & 7.15 & 5.56 & 6.14 \\
\hline $\mathrm{La}(0.01)$ & 0.016 & 0.001 & 0.005 & 0.008 & 0.000 & 0.005 \\
\hline $\mathrm{Li}(0.005)$ & 4.52 & 4.53 & 5.87 & 6.67 & 6.93 & 7.61 \\
\hline $\mathrm{Mg}(0.06)$ & 0.119 & 0.081 & 0.125 & 0.196 & 0.096 & 0.187 \\
\hline $\mathrm{Mn}(0.005)$ & 0.064 & 0.035 & 0.057 & 0.110 & 0.075 & 0.087 \\
\hline Mo $(0.02)$ & 0.030 & 0.026 & 0.027 & 0.034 & 0.029 & 0.029 \\
\hline $\mathrm{Na}(0.02)$ & 23.0 & 23.6 & 28.1 & 32.3 & 34.6 & 39.9 \\
\hline Nd $(0.03)$ & 0.067 & 0.006 & 0.029 & 0.035 & -0.003 & 0.010 \\
\hline $\mathrm{Ni}(0.03)$ & 0.029 & 0.003 & 0.003 & 0.026 & 0.013 & 0.011 \\
\hline$P(0.1)$ & 2.13 & 2.72 & 3.62 & 3.84 & 3.89 & 4.12 \\
\hline $\mathrm{Ru}(0.05)$ & 0.030 & 0.000 & 0.007 & 0.018 & -0.002 & -0.002 \\
\hline Sb (0.05) & 0.036 & -0.000 & 0.015 & 0.029 & 0.011 & 0.019 \\
\hline Si $(0.02)$ & 51.6 & 49.9 & 45.3 & 48.9 & 47.7 & 47.2 \\
\hline Sr $(0.003)$ & 0.002 & 0.000 & 0.002 & 0.002 & 0.001 & 0.001 \\
\hline Th $(0.15)$ & 0.252 & 0.057 & 0.054 & 0.118 & 0.071 & 0.086 \\
\hline $\mathrm{Ti}(0.005)$ & 0.047 & 0.015 & 0.024 & 0.043 & 0.027 & 0.027 \\
\hline $\mathrm{U}(0.015)$ & 0.500 & 0.577 & 0.800 & 0.588 & 0.559 & 1.77 \\
\hline $\mathrm{V}(0.01)$ & 0.011 & 0.002 & 0.003 & 0.007 & 0.002 & 0.003 \\
\hline$Y(0.01)$ & 0.005 & 0.001 & 0.001 & 0.002 & 0.000 & 0.001 \\
\hline $\operatorname{Zn}(0.02)$ & -0.017 & -0.015 & -0.014 & -0.012 & -0.015 & -0.015 \\
\hline $\operatorname{Zr}(0.01)$ & 0.015 & 0.004 & 0.007 & 0.003 & 0.000 & -0.001 \\
\hline
\end{tabular}

(a) Numbers in parentheses are instrument detection limits.

(b) Negative numbers are the result of random variation at low concentrations. 
Table A.1. (contd)

Days of Test

Date Test Began

Date Test Ended

Specimen Wgt., $g$

Leachant Volume, $\mathrm{mL}$

SA/V

Specimen Mesh Size

\begin{tabular}{|c|c|c|c|c|c|}
\hline WVDG-15 & WVDG-16 & WVDG-17 & WVDG-18 & WVDG-19 & WVDG-20 \\
\hline 7 & 7 & 7 & 7 & 7 & 7 \\
\hline $30-$ OCT-90 & $30-$ ОСТ-90 & 29-ОСТ-90 & $29-$ OCT-90 & $29-$ OCT-90 & 29-ОСТ-90 \\
\hline 06-NOV-90 & 06-NOV-90 & 05-NOV-90 & 05-NOV-90 & 05-NOV-90 & 05-NOV-90 \\
\hline 3.0423 & 3.1104 & 3.0257 & 3.0538 & 2.9820 & 3.0481 \\
\hline 30.42 & 31.10 & 30.25 & 30.54 & 29.79 & 30.48 \\
\hline 2000.2 & 2000.3 & 2000.5 & 1999.9 & 2002.0 & 2000.1 \\
\hline$-100+200$ & $-100+200$ & $-100+200$ & $-100+200$ & $-100+200$ & $-100+200$ \\
\hline 6.16 & 6.16 & 6.16 & 6.16 & 6.16 & 6.16 \\
\hline 9.76 & 9.29 & 10.00 & 9.78 & 9.73 & 9.33 \\
\hline 112.95 & 113.73 & 112.85 & 111.33 & 112.16 & 112.93 \\
\hline 111.86 & 111.76 & 111.60 & 110.07 & 109.89 & 111.94 \\
\hline $42-1$ & $38-1$ & $4-1$ & $24-1$ & $2-1$ & $25-1$ \\
\hline $11-D E C-90$ & 11-DEC-90 & 11-DEC-90 & 11-DEC-90 & 11-DEC-90 & 11-DEC-90 \\
\hline $90-7924$ & $90-7920$ & $90-7886$ & $90-7906$ & $90-7884$ & $90-7907$ \\
\hline
\end{tabular}

Elements

Leachate Analyzed Concentration, $\mathrm{mg} / \mathrm{L}$

\begin{tabular}{|c|c|c|c|c|c|c|}
\hline$A 1(0.05)^{(a)}$ & 11.2 & 11.3 & 11.0 & 13.2 & 17.4 & 14.3 \\
\hline $\mathrm{B}(0.01)$ & 23.1 & 15.3 & 17.8 & 14.9 & 14.2 & 10.2 \\
\hline $\mathrm{Ba}(0.005)$ & 0.003 & 0.006 & 0.004 & 0.007 & 0.004 & 0.005 \\
\hline $\mathrm{Ca}(0.02)$ & 0.034 & 0.057 & 0.358 & 0.046 & 0.059 & 0.059 \\
\hline $\mathrm{Cd}(0.005)$ & 0.000 & $-0.003^{(b)}$ & -0.001 & 0.000 & 0.000 & 0.001 \\
\hline $\mathrm{Ce}(0.05)$ & 0.028 & 0.023 & 0.020 & 0.033 & 0.008 & 0.028 \\
\hline $\operatorname{Cr}(0.02)$ & 0.029 & -0.001 & 0.033 & 0.004 & -0.001 & -0.000 \\
\hline $\mathrm{Cu}(0.005)$ & 0.004 & 0.000 & 0.005 & 0.001 & -0.001 & 0.002 \\
\hline $\mathrm{Fe}(0.01)$ & 0.331 & 0.433 & 0.392 & 1.79 & 0.326 & 0.201 \\
\hline$K(0.3)$ & 4.25 & 3.22 & 3.99 & 4.06 & 3.64 & 3.23 \\
\hline La $(0.01)$ & 0.002 & 0.001 & 0.002 & 0.002 & 0.001 & 0.003 \\
\hline $\mathrm{Li}(0.005)$ & 7.61 & 4.38 & 6.34 & 6.04 & 5.80 & 4.35 \\
\hline $\mathrm{Mg}(0.06)$ & 0.137 & 0.072 & 0.134 & 0.012 & 0.086 & 0.054 \\
\hline $\operatorname{Mn}(0.005)$ & 0.100 & 0.071 & 0.109 & 0.050 & 0.012 & 0.009 \\
\hline Mo $(0.02)$ & 0.240 & 0.042 & 0.275 & 0.055 & 0.060 & 0.125 \\
\hline $\mathrm{Na}(0.02)$ & 39.7 & 22.2 & 42.6 & 36.0 & 32.1 & 17.2 \\
\hline Nd (0.03) & 0.012 & 0.007 & 0.016 & 0.004 & 0.004 & 0.009 \\
\hline $\mathrm{Ni}(0.03)$ & 0.016 & 0.006 & 0.030 & 0.021 & -0.001 & 0.009 \\
\hline$P(0.1)$ & 2.81 & 2.69 & 2.86 & 2.38 & 2.09 & 1.75 \\
\hline $\mathrm{Ru}(0.05)$ & 0.003 & 0.005 & 0.001 & -0.002 & -0.001 & 0.007 \\
\hline Sb $(0.05)$ & 0.020 & -0.001 & 0.014 & -0.007 & -0.005 & 0.003 \\
\hline Si $(0.02)$ & 49.2 & 46.6 & 46.1 & 54.3 & 43.0 & 40.5 \\
\hline Sr $(0.003)$ & 0.000 & 0.000 & 0.001 & 0.001 & 0.000 & 0.001 \\
\hline $\operatorname{Th}(0.15)$ & 0.014 & 0.033 & 0.046 & 0.204 & 0.028 & 0.040 \\
\hline $\mathrm{Ti}(0.005)$ & 0.014 & 0.007 & 0.018 & 0.035 & 0.005 & 0.023 \\
\hline $\mathrm{U}(0.015)$ & 1.24 & 0.102 & 0.032 & 0.126 & 1.06 & 0.152 \\
\hline$V(0.01)$ & 0.002 & 0.001 & 0.003 & 0.003 & 0.003 & 0.002 \\
\hline$Y(0.01)$ & 0.001 & 0.001 & 0.001 & 0.001 & 0.001 & 0.001 \\
\hline $\operatorname{Zn}(0.02)$ & -0.012 & -0.014 & 0.441 & -0.010 & -0.017 & -0.011 \\
\hline $\mathrm{Zr}(0.01)$ & 0.001 & 0.002 & -0.001 & 0.002 & 0.002 & 0.010 \\
\hline
\end{tabular}

(a) Numbers in parentheses are instrument detection limits.

(b) Negative numbers are the result of random variation at low concentrations. 
Table A.1. (contd)

Days of Test

Date Test Began

Date Test Ended

WVDG-21
7
30-OCT-90
O6-NOV-90

Specimen Wgt.,

Leachant Volume, $\mathrm{mL}$

SA/V

Specimen Mesh Size

30.93

2064.7

$-100+200$

WVDG-22 WVDG-23

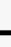

7

$30-0 C T-90$

7

06-NOV-90 06-NOV-90

30-OCT-90

06-NOV-90

29-OCT-90

05-NOV-90

Initial $\mathrm{pH}$

6.16

9.53

3.1301

3.1439

3.0863

3.0439

31.31

31.43

2000.6

30.85

30.43

3.0672

$-100+200 \quad-100+200$

$-8$

2000.6

30.66

2000.8

Final $\mathrm{pH}$

6.16

6.16

$-100+200$

$-100+200$

$-100+200$

Total Init. Wgt., g

Total Final Weight, $g$

9.26

9.21

6.16

6.16

6.16

$113.79-113.90$

113.880

9.43

9.44

9.42

111.55

112.14

111.880

110.380

113.340

110.850

26-1

Run Order and Blind
Date of Analysis

Analytical Number

11-DEC-90 11-DEC-90

47-1

11-DEC-90

107.760

112.550

109.270

90-7908

90-7914

90-7929

6-1

37-1.

18-1

11-DEC-90 11-DEC-90 11-DEC-90

90-7888 90-7919

90-7900

Leachate Anslyzed Concentration, $\mathrm{mg} / \mathrm{L}$

Al $(0.05)^{(a)}$

B $(0.01)$

$\mathrm{Ba}(0.005)$

$\mathrm{Ca}(0.02)$

$\mathrm{Cd}(0.005)$

$\mathrm{Ce}(0.05)$

Cr $(0.02)$

$\mathrm{Cu}(0.005)$

$\mathrm{Fe}(0.01)$

$\mathrm{K}(0.3)$

La $(0.01)$

Li (0.005)

Mg (0.06)

$\mathrm{Mn}(0.005)$

Mo (0.02)

$\mathrm{Na}(0.02)$

Nd $(0.03)$

Ni (0.03)

$\mathrm{P}(0.1)$

Ru (0.05)

$\mathrm{Sb}(0.05)$

Si $(0.02)$

Sr $(0.003)$

Th $(0.15)$

Ti $(0.005)$

$\mathrm{U}(0.015)$

$\mathrm{V}(0.01)$

Y $(0.01)$

$\mathrm{Zn}(0.02)$

$\mathrm{Zr}(0.01)$

lements

\begin{tabular}{|c|c|c|c|c|c|}
\hline 22.4 & 20.5 & 14.6 & 17.1 & 12.4 & 13.8 \\
\hline 15.1 & 16.0 & 21.0 & 19.5 & 12.8 & 15.8 \\
\hline 0.027 & 0.007 & 0.020 & 0.005 & 0.004 & 0.005 \\
\hline 0.145 & 0.066 & 0.087 & 0.067 & 0.029 & 0.053 \\
\hline 0.003 & 0.003 & $-0.002^{(b)}$ & 0.000 & 0.001 & 0.001 \\
\hline 0.155 & 0.203 & 0.123 & 0.039 & 0.042 & 0.008 \\
\hline 0.022 & -0.001 & 0.027 & 0.002 & 0.007 & 0.003 \\
\hline 0.012 & 0.016 & 0.012 & 0.004 & 0.004 & 0.001 \\
\hline 4.76 & 0.780 & 4.97 & 0.745 & 0.685 & 0.266 \\
\hline 4.89 & 4.42 & 1.71 & 3.88 & 3.44 & 3.26 \\
\hline 0.011 & 0.017 & 0.005 & 0.007 & 0.007 & 0.005 \\
\hline 5.80 & 5.34 & 5.50 & 6.11 & 4.84 & 4.92 \\
\hline 0.091 & 0.039 & 0.071 & 0.043 & 0.021 & 0.080 \\
\hline 0.631 & 0.171 & 0.113 & 0.166 & 0.103 & 0.016 \\
\hline 0.054 & 0.184 & 0.042 & 0.049 & 0.039 & 0.051 \\
\hline 36.7 & 23.4 & 24.3 & 26.2 & 22.3 & 21.7 \\
\hline 0.046 & 0.066 & 0.018 & 0.028 & 0.021 & 0.024 \\
\hline 0.031 & 0.014 & 0.018 & 0.020 & 0.012 & 0.009 \\
\hline 4.45 & 1.41 & 2.79 & 1.98 & 2.60 & 1.46 \\
\hline 0.004 & 0.016 & -0.007 & 0.004 & 0.007 & 0.006 \\
\hline 0.017 & 0.009 & 0.000 & -0.003 & 0.005 & 0.022 \\
\hline 56.1 & 52.4 & 56.6 & 51.0 & 55.2 & 40.8 \\
\hline 0.003 & 0.003 & 0.002 & 0.002 & 0.001 & 0.002 \\
\hline 0.823 & 0.344 & 2.362 & 0.106 & 0.245 & 0.060 \\
\hline 0.117 & 0.088 & 0.133 & 0.021 & 0.021 & 0.012 \\
\hline 1.67 & 0.165 & 1.86 & 1.00 & 0.105 & 0.086 \\
\hline 0.010 & 0.009 & 0.014 & 0.004 & 0.004 & 0.004 \\
\hline 0.005 & 0.008 & 0.003 & 0.002 & 0.002 & 0.001 \\
\hline-0.009 & -0.008 & -0.008 & -0.016 & -0.012 & -0.013 \\
\hline 0.001 & 0.010 & 0.000 & 0.010 & 0.008 & 0.002 \\
\hline
\end{tabular}

(a) Numbers in parentheses are instrument detection limits.

(b) Negative numbers are the result of random variation at low concentrations. 
Table A.1. (contd)

Days of Test

Date Test Began

Date Test Ended

Specimen Wgt., g

Leachant Volume, mL.

SAVV

Specimen Mesh Size

Initial pH

Final pH

Total Init. Wgt., g

Total Final Weight, 8

Run Order and Blind $\mathrm{Na}$

Date of Analysis

Analytical Number

\begin{tabular}{|c|c|c|c|c|c|c|c|}
\hline WVDG-27 & WVDG-28 & WVDG-29 & WVDG-30 & WVDG-31B & WVDG-31C & WVDG-33 & WVDG-34 \\
\hline 7 & 7 & 7 & 7 & 7 & 7 & 7 & 7 \\
\hline 30-OCT-90 & 29-OCT-90 & $30-$ OCT-90 & 29-ОCT-90 & 29-0CT-9 & $30-0 C T-9$ & 29-ОСТ-90 & $30-0 \mathrm{CT}-90$ \\
\hline 06-NOV-90 & 05-NOV-90 & 06-NON-90 & 05-NOV-90 & 05-NOV-9 & 06-NON-9 & 05-NOV-90 & O6-NON-90 \\
\hline 3.0599 & 3.0425 & 3.3036 & 3.1366 & 3.057 & 3.3580 & 3.0584 & 3.0256 \\
\hline 30.60 & 30.42 & 33.03 & 31.38 & 30.52 & 33.58 & 30.59 & 30.25 \\
\hline 1999.9 & 2000.3 & 2000.4 & 1999.1 & 1999.8 & 2000.0 & 1999.6 & 2000.4 \\
\hline$-100+200$ & $-100+200$ & $-100+200$ & $-100+200$ & $-100+200$ & $-100+200$ & $-100+200$ & $-100+200$ \\
\hline 6.16 & 6.16 & 6.16 & 6.16 & 6.16 & 6.16 & 6.16 & 6.16 \\
\hline 9.44 & 9.45 & 9.68 & 9.52 & 9.59 & 9.75 & 10.06 & 9.85 \\
\hline 111.020 & 110.960 & 115.900 & 112.610 & 110.87 & 116.21 & 112.83 & 113.53 \\
\hline 109.830 & 109.590 & 114.690 & 110.880 & 109.28 & 115.18 & 112.37 & 105.84 \\
\hline $29-1$ & $23-1$ & $39-1$ & $16-1$ & $20-1$ & $40-1$ & $22-1$ & $46-1$ \\
\hline 11-DEC-90 & 11-DEC-90 & 11-DEC-90 & 11-DEC-90 & 11-DEC-90 & 11-DEC-90 & 11-DEC-90 & 11-DEC-90 \\
\hline $90-7911$ & $90-7905$ & $90-7921$ & $90-7898$ & $90-7902$ & $90-7922$ & $90-7904$ & $90-7928$ \\
\hline
\end{tabular}

Elements

Leachate Analyzod Concentration, mg/L

Al $(0.05)^{(a)}$

$\mathrm{B}(0.01)$

$\mathrm{Ba}(0.005)$

$\mathrm{Ca}(0.02)$

$\mathrm{Cd}(0.005)$

$\mathrm{Ce}(0.05)$

Cr $(0.02)$

$\mathrm{Cu}(0.005)$

Fe $(0.01)$

$\mathrm{K}(0.3)$

La $(0.01)$

Li $(0.005)$

$\mathrm{Mg}(0.06)$

Mn (0.005)

Mo (0.02)

$\mathrm{Na}(0.02)$

Nd (0.03)

Ni $(0.03)$

P (0.1)

Ru (0.05)

$\mathrm{Sb}(0.05)$

Si (0.02)

Sr (0.003)

Th (0.15)

Ti (0.005)

$\mathrm{U}(0.015)^{(\mathrm{d})}$

$\mathrm{V}(0.01)$

$\mathrm{Y}(0.01)$

Zn (0.02)

$\mathrm{Zr}(0.01)$

\begin{tabular}{|c|c|c|c|c|}
\hline 21.3 & 13:1 & 9.75 & 13.4 & 12.9 \\
\hline 23.8 & 12.9 & 15.2 & 15.4 & 13.9 \\
\hline 0.006 & 0.008 & 0.007 & 0.003 & 0.003 \\
\hline 0.053 & 0.053 & 0.067 & 0.063 & 0.046 \\
\hline 0.001 & 0.000 & 0.001 & 0.001 & $-0.002^{(c)}$ \\
\hline 0.182 & 0.166 & 0.044 & 0.013 & 0.007 \\
\hline 0.028 & 0.013 & 0.001 & 0.007 & 0.010 \\
\hline 0.016 & 0.013 & 0.003 & 0.002 & 0.000 \\
\hline 1.32 & 1.44 & 0.636 & 0.338 & 0.868 \\
\hline 4.54 & 3.07 & 4.84 & 3.65 & 5.28 \\
\hline 0.014 & 0.010 & 0.007 & 0.004 & 0.005 \\
\hline 6.75 & 5.25 & 5.96 & 5.15 & 5.89 \\
\hline 0.024 & 0.033 & 0.273 & 0.034 & 0.198 \\
\hline 0.038 & 0.047 & 0.039 & 0.024 & 0.102 \\
\hline 0.184 & 0.172 & 0.052 & 0.106 & 0.035 \\
\hline 36.1 & 21.4 & 33.7 & 27.7 & 28.0 \\
\hline 0.048 & 0.031 & 0.023 & 0.020 & 0.015 \\
\hline 0.021 & 0.023 & 0.013 & 0.011 & 0.015 \\
\hline 3.49 & 1.50 & 5.71 & 2.62 & 3.73 \\
\hline 0.010 & 0.002 & 0.006 & 0.005 & 0.003 \\
\hline 0.005 & 0.007 & 0.011 & 0.018 & 0.009 \\
\hline 52.4 & 54.2 & 49.8 & 45.9 & 46.3 \\
\hline 0.002 & 0.002 & 0.000 & 0.001 & 0.002 \\
\hline 0.580 & 0.280 & 0.070 & 0.055 & 0.095 \\
\hline 0.070 & 0.141 & 0.012 & 0.013 & 0.042 \\
\hline 0.075 & 0.813 & 0.177 & 0.559 & 0.744 \\
\hline 0.009 & 0.004 & 0.004 & 0.004 & 0.004 \\
\hline 0.006 & 0.005 & 0.002 & 0.001 & 0.002 \\
\hline-0.005 & -0.007 & -0.012 & -0.015 & -0.014 \\
\hline 0.001 & 0.004 & 0.004 & 0.007 & -0.001 \\
\hline
\end{tabular}

$\begin{array}{lc}9.86 & 6.83(\text { b) } \\ 13.4 & 31.7 \\ 0.002 & 0.002 \\ 0.039 & 0.044 \\ -0.002 & -0.001 \\ 0.003 & 0.031 \\ 0.005 & 0.066 \\ 0.002 & 0.014 \\ 0.974 & 0.669 \\ 7.93 & 10.9 \\ -0.001 & 0.004 \\ 6.75 & 12.8 \\ 0.155 & 0.024 \\ 0.103 & 0.124 \\ 0.143 & 0.642 \\ 36.6 & 67.9 \\ -0.010 & 0.015 \\ 0.022 & 0.059 \\ 4.29 & 4.58 \\ -0.002 & -0.002 \\ 0.012 & 0.008 \\ 52.5 & 67.6 \\ 0.001 & 0.003 \\ 0.125 & 0.092 \\ 0.032 & 0.105 \\ 0.607 & 0.987 \\ 0.002 & 0.003 \\ 0.000 & 0.001 \\ -0.009 & -0.003 \\ 0.000 & 0.001\end{array}$

(a) Numbes in parentheses are instrument detection limits.

(b) Data excluded from calculations because leachant loss $>10 \%$.

(c) Nogative numbes are the result of random variation at low concentnations. 
Table A.1. (contd)

Days of Test

Date Test Began

Date Test Ended

Specimen Wgt., g

Leachant Volume, $\mathrm{mL}$

SA/V

Specimen Mesh Size

Initial pH

Final pH

Total Init. Wgt., g

Total Final Weight, $g$

Run Onder and Blind No.

Date of Analysis

Analytical Number

\section{Bv}

7

$\begin{array}{lll}30-O C T-90 & 30-O C T-90 & 29-O C T-90 \\ \text { 06-NOV-90 } & \text { 06-NOV-90 } & \text { 05-NOV-90 }\end{array}$

$\begin{array}{lll}3.0225 & 3.0198 & 3.0298\end{array}$

$30.22 \quad 30.21$

$\begin{array}{ll}2000.3 & 1999.2\end{array}$

$-100+200-100+200$

30.31

1999.2

$-100+200$

6.16

10.82

6.16

9.47

6.16

10.49

111.66

110.53

112.86

111.54

112.81

109.99

33-1

43-1

$11-D E C-90$

90-7925

11-DEC-90 5-1

90-7915
5-1

90-7887

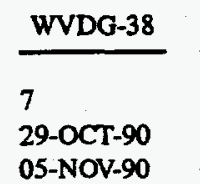

WVDG-39

7

30-OCT-90

06-NOV-90

3.1003

31.01

1999.5

3.1675

31.67

2000.3

$-100+200$

$-100+200$

6.16

10.08

6.16

9.77

111.34

110.88

113.64

111.70

13-1

11-DEC-90

90-7895
50-1 14-1

11-DEC-90 11-DEC-90

90-7932

90-7896
WVDG-40

7

29-OCT-90

05-NOV-90

3.0370

30.37

2000.0

$-100+200$

6.16

10.09

112.80

110.08
Elements

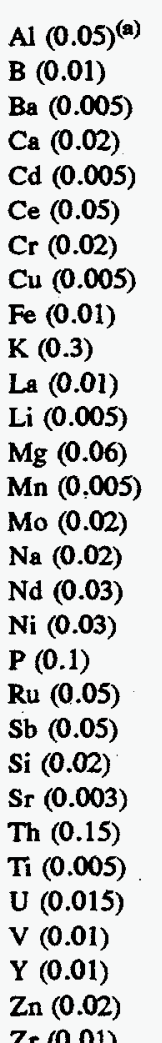

Al $(0.05)^{(a)}$

Ba $(0.005)$

$\mathrm{Ca}(0.02)$

Cd (0.005)

$\mathrm{Ce}(0.05)$

$\mathrm{Cu}(0.005)$

La $(0.01)$

Li (0.005)

$\mathrm{Mg}(0.06)$

Mo (0.02)

Ni $(0.03)$

$P(0.1)$

Ru (0.05)

Si (0.02)

Sr $(0.003)$

Th (0.15)

Ti $(0.005)$

$\mathrm{V}(0.01)$

$\mathrm{Zn}(0.02)$

$\mathrm{Zr}(0.01)$
Leachate Analyzed Concentration, mg/L

$\begin{array}{llllll}19.6 & 6.62 & 16.9 & 14.6 & 12.6 & 5.92 \\ 18.1 & 16.4 & 12.0 & 9.35 & 18.4 & 14.1 \\ 0.005 & 0.003 & 0.003 & 0.001 & 0.002 & 0.002 \\ 0.034 & 0.042 & 0.034 & 0.068 & 0.030 & 0.091 \\ -0.002^{(b)} & 0.003 & -0.001 & -0.002 & -0.003 & 0.002 \\ -0.001 & 0.075 & 0.026 & 0.014 & 0.034 & 0.003 \\ 0.002 & 0.006 & 0.031 & 0.019 & -0.002 & 0.001 \\ 0.001 & 0.017 & 0.022 & 0.006 & 0.002 & 0.001 \\ 2.74 & 0.658 & 1.26 & 0.549 & 0.615 & 0.759 \\ 13.7 & 7.17 & 9.77 & 6.24 & 8.99 & 8.80 \\ -0.001 & 0.020 & 0.009 & 0.007 & 0.004 & 0.003 \\ 11.7 & 5.00 & 8.93 & 6.13 & 6.96 & 7.60 \\ 0.389 & 0.039 & 0.045 & 0.008 & 0.230 & 0.242 \\ 0.250 & 0.006 & 0.011 & 0.075 & 0.005 & 0.005 \\ 0.089 & 0.377 & 0.446 & 0.378 & 0.069 & 0.086 \\ 67.8 & 22.5 & 51.2 & 28.9 & 39.7 & 41.2 \\ -0.007 & 0.072 & 0.027 & 0.013 & 0.007 & 0.004 \\ 0.008 & 0.010 & 0.095 & 0.009 & 0.010 & 0.001 \\ 1.55 & 0.644 & 0.899 & 0.756 & 6.56 & 1.14 \\ -0.010 & 0.029 & 0.002 & 0.000 & -0.001 & 0.001 \\ -0.025 & 0.038 & 0.006 & -0.002 & -0.001 & 0.019 \\ 66.5 & 50.3 & 60.2 & 49.6 & 44.2 & 61.4 \\ 0.001 & 0.002 & 0.003 & 0.003 & 0.000 & 0.001 \\ 0.069 & 0.299 & 0.240 & 0.152 & 0.079 & 0.056 \\ 0.014 & 0.090 & 0.209 & 0.089 & 0.010 & 0.006 \\ 3.61 & 0.157 & 0.138 & 0.298 & 0.126 & 2.28 \\ 0.002 & 0.012 & 0.004 & 0.003 & 0.003 & 0.004 \\ -0.000 & 0.005 & 0.004 & 0.003 & 0.001 & 0.001 \\ -0.025 & -0.010 & 0.005 & -0.008 & -0.013 & -0.021 \\ -0.000 & 0.040 & 0.026 & 0.019 & -0.000 & -0.000 \\ & & & & & \end{array}$

(a) Numbers in parentheses are instrument detection limits.

(b) Negative numbers are the result of random variation at low concentrations. 
Table A.1. (contd)

Days of Test

Date Test Began

Date Test Ended

WVDG-41

Specimen Wgt., $\mathrm{g}$

79-TT 90

$70-100$

05-NOV-90

06-NOV-90

$3.2295 \quad 3.0256$

3.2295

3.0256

2000.4

3.0513

30.51

$\mathrm{SA} / \mathrm{V}$

$-100+200 \quad-100+200$

2000.2

WVDG-43

WVDG-44

WVDG-45

WVDG-46

77

7

7

Specimen Mesh Size

$6.16 \quad 6.16$

$10.42 \quad 10.21$

6.16

9.26

$30-$ OCT-90

29-OCT-90

7

05-NOV-90 06-NOV-90

05-NOV-90

30-OCT-90

06-NOV-90

Initial pH

114.67

112.56

106.57

3.4579

2.8213

34.59

1999.4

2000

3.1170

31.11

$100+200$

$-100+200$

2003.9

Total Init. Wgt.,

113.41

111.02

104.59

6.16

6.16

$-100+200$

Total Final Weight, $\mathrm{g}$

8-1

30-1

9-1

10.15

10.44

6.16

11-DEC-90

11-DEC-90

11-DEC-90

116.77

108.28

107.91

113.88

90-7890

90-7912

90-7891

58-1

1-1

41-1

Analytical Number

Elements

$\mathrm{Al}(0.05)^{(\mathbf{a})}$

B $(0.01)$

Ba (0.005)

$\mathrm{Ca}(0.02)$

Cd (0.005)

$\mathrm{Ce}(0.05)$

Cr (0.02)

$\mathrm{Cu}(0.005)$

Fe $(0.01)$

$\mathrm{K}(0.3)$

La $(0.01)$

Li $(0.005)$

Mg (0.06)

Mn (0.005)

Mo (0.02)

$\mathrm{Na}(0.02)$

Nd $(0.03)$

Ni $(0.03)$

$P(0.1)$

$\mathrm{Ru}(0.05)$

$\mathrm{Sb}(0.05)$

Si $(0.02)$

Sr (0.003)

Th $(0.15)$

Ti $(0.005)$

$\mathrm{U}(0.015)$

$\mathrm{V}(0.01)$

$\mathrm{Y}(0.01)$

$\mathrm{Zn}(0.02)$

$\mathrm{Zr}(0.01)$

西

Leachate Analyzed Concentration, $\mathrm{mg} / \mathrm{L}$

\begin{tabular}{llllll}
\hline 7.99 & 5.49 & 15.4 & 13.2 & 17.1 & 8.21 \\
14.2 & 16.8 & 17.4 & 25.3 & 11.7 & 28.3 \\
0.004 & 0.004 & 0.007 & 0.001 & 0.003 & 0.003 \\
0.043 & 0.045 & 0.085 & 0.021 & 0.066 & 0.034 \\
0.000 & 0.002 & $-0.000^{(b)}$ & -0.001 & 0.002 & -0.000 \\
0.026 & 0.031 & 0.037 & 0.009 & 0.012 & -0.003 \\
0.002 & 0.020 & 0.026 & -0.001 & 0.014 & 0.003 \\
0.007 & 0.031 & 0.021 & 0.002 & 0.003 & 0.000 \\
1.42 & 1.62 & 6.18 & 1.31 & 2.12 & 1.41 \\
11.9 & 13.8 & 4.42 & 9.31 & 10.3 & 8.53 \\
0.008 & 0.007 & 0.011 & 0.001 & 0.002 & -0.003 \\
8.62 & 10.3 & 5.91 & 9.91 & 7.82 & 8.50 \\
0.053 & 0.491 & 0.088 & 0.021 & 0.028 & 0.459 \\
0.013 & 0.279 & 0.602 & 0.006 & 0.227 & 0.255 \\
0.078 & 0.770 & 0.043 & 0.060 & 0.104 & 0.063 \\
61.9 & 60.6 & 17.7 & 52.7 & 51.4 & 46.0 \\
0.029 & 0.029 & 0.032 & -0.005 & 0.004 & -0.006 \\
0.016 & 0.129 & 0.045 & 0.008 & 0.015 & 0.008 \\
9.95 & 11.9 & 2.18 & 0.933 & 8.97 & 1.02 \\
0.003 & 0.013 & -0.004 & -0.006 & -0.004 & -0.005 \\
0.002 & 0.027 & 0.006 & -0.023 & 0.005 & 0.002 \\
66.2 & 67.3 & 56.3 & 55.6 & 53.1 & 62.1 \\
0.002 & 0.002 & 0.002 & 0.000 & 0.001 & -0.000 \\
0.341 & 0.092 & 2.09 & 0.216 & 0.220 & 0.168 \\
0.024 & 0.087 & 0.167 & 0.018 & 0.048 & 0.018 \\
2.73 & 0.067 & 3.72 & 2.37 & 0.169 & 0.209 \\
0.006 & 0.008 & 0.015 & 0.002 & 0.003 & 0.001 \\
0.002 & 0.002 & 0.005 & 0.001 & 0.001 & -0.000 \\
-0.024 & 0.014 & -0.014 & -0.021 & -0.009 & -0.010 \\
0.003 & 0.005 & 0.008 & 0.002 & -0.001 & -0.002 \\
& & & & &
\end{tabular}

(a) Numbers in parentheses are instrument detection limits.

(b) Negative numbers are the result of random variation at low concentrations. 
Table A.1. (contd)

\begin{tabular}{|c|c|c|c|c|c|c|}
\hline & WVDG-47 & WVDG-48 & $\begin{array}{l}\text { WVDG-49 } \\
\text { (ARM-1) }\end{array}$ & $\begin{array}{l}\text { WVDG-50 } \\
\text { (ARM-1) }\end{array}$ & $\begin{array}{c}\text { WVDG-51 } \\
\text { (Blank) }\end{array}$ & $\begin{array}{c}\text { WVDG-52 } \\
\text { (Blank) }\end{array}$ \\
\hline Days of Test & 7 & 7 & 7 & 7 & 7 & 7 \\
\hline Date Test Began & $30-$ OCT-90 & $30-0 C T-90$ & $29-$ OCT-90 & $29-$ ОСТ-90 & $30-$ OCT-90 & $29-$ OCT- 90 \\
\hline Date Test Ended & 06-NOV-90 & 06-NOV-90 & O5-NOV-90 & 05-NOV-90 & O6-NOV-90 & 05-NOV-90 \\
\hline Specimen Wgt., g & 3.0617 & 3.1124 & 3.9049 & 3.1206 & no specimen & no specimen \\
\hline Leachant Volume, $\mathrm{mL}$ & 30.62 & 31.14 & 39.05 & 31.21 & 32.87 & 29.47 \\
\hline SAIV & 1999.8 & 1999.0 & 1999.9 & 1999.7 & & \\
\hline Specimen Mesh Size & $-100+200$ & $-100+200$ & $-100+200$ & $-100+200$ & $-100+200$ & $-100+200$ \\
\hline Initial pH & 6.16 & 6.16 & 6.16 & 6.16 & 6.16 & 6.16 \\
\hline Final $\mathrm{pH}$ & 9.23 & 9.21 & 10.13 & 10.22 & 9.55 & 9.41 \\
\hline Total Init. Wgt., g & 111.52 & 113.70 & 118.66 & 113.54 & 111.19 & 108.86 \\
\hline Total Final Weight, $g$ & 110.17 & 111.06 & 115.30 & 112.28 & 111.02 & 108.51 \\
\hline Run Order and Blind No. & $35-1$ & $27-1$ & $12-1$ & $17-1$ & 44-1 & $11-1$ \\
\hline Date of Analysis & 11-DEC-90 & 11-DEC-90 & $11-D E C-90$ & 11-DEC-90 & 11-DEC-90 & 11-DEC-90 \\
\hline Analytical Number & $90-7917$ & $90-7909$ & $90-7894$ & $90-7899$ & $90-7926$ & $90-7893$ \\
\hline Elements & \multicolumn{6}{|c|}{ Leachate Analyzed Concentration, $\mathrm{mg} / \mathrm{L}$} \\
\hline $\mathrm{Al}(0.05)^{(\mathrm{a})}$ & 7.50 & 13.4 & 4.83 & 4.60 & $-0.014^{(b)}$ & 0.005 \\
\hline$B(0.01)$ & 15.6 & 12.5 & 19.4 & 16.9 & 0.057 & 0.012 \\
\hline $\mathrm{Ba}(0.005)$ & 0.007 & 0.006 & 0.011 & 0.005 & -0.000 & 0.001 \\
\hline $\mathrm{Ca}(0.02)$ & 0.064 & 0.075 & 0.186 & 0.219 & 0.021 & 0.060 \\
\hline $\mathrm{Cd}(0.005)$ & 0.003 & 0.002 & -0.001 & -0.000 & -0.002 & -0.001 \\
\hline $\mathrm{Ce}(0.05)$ & 0.088 & 0.047 & 0.038 & 0.013 & 0.005 & -0.001 \\
\hline Cr $(0.02)$ & 0.020 & 0.000 & 0.003 & -0.002 & -0.000 & 0.000 \\
\hline $\mathrm{Cu}(0.005)$ & 0.020 & 0.017 & 0.002 & 0.004 & -0.004 & -0.001 \\
\hline Fe $(0.01)$ & 6.71 & 0.350 & -0.009 & -0.030 & -0.042 & -0.004 \\
\hline$K(0.3)$ & 6.80 & 5.90 & 0.000 & 0.488 & -0.623 & 0.036 \\
\hline La $(0.01)$ & 0.021 & 0.011 & 0.005 & 0.007 & -0.002 & 0.002 \\
\hline $\mathrm{Li}(0.005)$ & 4.82 & 4.53 & 16.1 & 13.5 & 0.006 & 0.010 \\
\hline $\mathrm{Mg}(0.06)$ & 0.113 & 0.071 & 0.034 & 0.044 & -0.009 & 0.018 \\
\hline $\operatorname{Mn}(0.005)$ & 0.592 & 0.005 & 0.000 & 0.000 & -0.001 & -0.001 \\
\hline Mo $(0.02)$ & 0.053 & 0.272 & 6.221 & 5.563 & 0.002 & 0.002 \\
\hline $\mathrm{Na}(0.02)$ & 20.0 & 16.4 & 41.6 & 36.2 & 0.068 & 0.051 \\
\hline Nd $(0.03)$ & 0.078 & 0.035 & 0.144 & 0.042 & -0.009 & 0.002 \\
\hline $\mathrm{Ni}(0.03)$ & 0.031 & 0.014 & -0.003 & -0.001 & 0.000 & -0.006 \\
\hline$P(0.1)$ & 4.83 & 2.60 & 0.947 & 0.887 & 0.023 & 0.020 \\
\hline $\mathrm{Ru}(0.05)$ & 0.022 & 0.014 & 0.007 & 0.013 & -0.010 & -0.002 \\
\hline Sb $(0.05)$ & 0.029 & 0.021 & 0.018 & 0.027 & -0.019 & 0.011 \\
\hline Si $(0.02)$ & 58.2 & 45.4 & 65.2 & 59.8 & -0.007 & 0.074 \\
\hline Sr $(0.003)$ & 0.003 & 0.002 & 0.016 & 0.022 & -0.000 & 0.001 \\
\hline Th $(0.15)$ & 0.990 & 0.106 & 0.014 & 0.011 & -0.001 & 0.026 \\
\hline $\mathrm{Ti}(0.005)$ & 0.123 & 0.075 & 0.061 & 0.012 & -0.001 & 0.001 \\
\hline $\mathrm{U}(0.015)$ & 0.372 & 0.244 & NA & NA & & \\
\hline$V(0.01)$ & 0.015 & 0.006 & 0.009 & 0.010 & -0.003 & -0.000 \\
\hline$Y(0.01)$ & 0.007 & 0.004 & 0.001 & 0.002 & -0.001 & -0.000 \\
\hline $\mathrm{Zn}(0.02)$ & -0.008 & -0.006 & 0.072 & 0.032 & -0.013 & -0.013 \\
\hline $\mathrm{Zr}(0.01)$ & 0.008 & 0.010 & 0.037 & 0.011 & -0.003 & -0.002 \\
\hline
\end{tabular}

(a) Numbers in parentheses are instrument detection limits.

(b) Negative numbers are the result of random variation at low concentrations. 
Table A.2. Test Information and Leachate ICP and XRF Results for Second Series of PCT Tests of West Valley Compositional Variability Glasses

\begin{tabular}{|c|c|c|c|c|c|c|}
\hline & WVDG-1 & WVDG-2 & WVDG-3 & WVDG-4 & WVDG-5 & WVDG-6 \\
\hline Days of Test & 7 & 7 & 7 & 7 & 7 & 7 \\
\hline Date Test Began & 12-NOV-90 & 12-NOV-90 & 12-NOV-90 & 13-NOV-90 & 12-NOV-90 & 12-NOV-90 \\
\hline Date Test Ended & 19-NOV-90 & 19-NOV-90 & 19-NOV-90 & 20-NOV-90 & 19-NOV-90 & 19-NOV-90 \\
\hline Specimen Wgt., $\mathbf{g}$ & 3.1085 & 3.0771 & 3.1807 & 3.0870 & 3.1250 & 3.0609 \\
\hline Leachant Volume, $\mathrm{mL}$ & 31.08 & 30.76 & 31.82 & 30.88 & 31.25 & 30.61 \\
\hline SA/V & 2000.3 & 2000.7 & 1999.2 & 1999.4 & 2000.0 & 1999.9 \\
\hline Specimen Mesh Size & $-100+200$ & $-100+200$ & $-100+200$ & $-100+200$ & $-100+200$ & $-100+200$ \\
\hline Initial pH & 6.14 & 6.14 & 6.14 & 6.14 & 6.14 & 6.14 \\
\hline Final pH. & 9.42 & 9.50 & 9.74 & 9.80 & 9.47 & 9.43 \\
\hline Total Init. Wgt., g & 113.84 & 112.45 & 114.24 & 112.24 & 110.73 & 111.25 \\
\hline Total Final Weight, $\mathbf{g}$ & 112.50 & 112.26 & 113.98 & 109.64 & 110.22 & 109.90 \\
\hline Run Order and Blind No. & $11-2$ & $10-2$ & $5-2$ & $27-2$ & $2-2$ & $18-2$ \\
\hline Date of Analysis & 12-DEC-90 & 12-DEC-90 & 12-DEC-90 & 12-DEC-90 & 12-DEC-90 & 12-DEC-90 \\
\hline Analytical Number & $90-7991$ & $90-7990$ & $90-7985$ & $90-8007$ & $90-7982$ & $90-7998$ \\
\hline Elements & \multicolumn{6}{|c|}{ Leachate Analyzed Concentration, $\mathrm{mg} / \mathrm{L}$} \\
\hline $\mathrm{Al}(0.05)^{(\mathrm{a})}$ & 11.3 & 10.0 & 7.50 & 9.68 & 6.38 & 10.2 \\
\hline B $(0.01)$ & 13.7 & 15.2 & 14.6 & 18.9 & 15.7 & 14.8 \\
\hline $\mathrm{Ba}(0.005)$ & 0.004 & 0.001 & 0.002 & 0.002 & 0.001 & 0.002 \\
\hline $\mathrm{Ca}(0.02)$ & 0.073 & 0.099 & 0.034 & 0.031 & 0.058 & 0.040 \\
\hline $\mathrm{Cd}(0.005)$ & $-0.001^{(b)}$ & 0.001 & 0.000 & 0.001 & 0.001 & 0.001 \\
\hline $\mathrm{Ce}(0.05)$ & 0.031 & 0.024 & 0.022 & 0.030 & 0.010 & 0.026 \\
\hline $\mathrm{Cr}(0.02)$ & 0.012 & 0.004 & 0.017 & 0.007 & 0.006 & 0.001 \\
\hline $\mathrm{Cu}(0.005)$ & 0.002 & 0.000 & -0.000 & 0.001 & -0.001 & 0.002 \\
\hline $\mathrm{Fe}(0.01)$ & 1.40 & 0.578 & 0.791 & 0.600 & 0.415 & 0.478 \\
\hline $\mathrm{K}(0.3)$ & 2.29 & 1.65 & 3.47 & 1.92 & 1.97 & 2.24 \\
\hline La $(0.01)$ & 0.008 & 0.004 & 0.003 & 0.005 & 0.002 & 0.006 \\
\hline Li (0.005) & 4.10 & 4.90 & 6.56 & 4.79 & 4.48 & 4.77 \\
\hline $\mathrm{Mg}(0.06)$ & 0.149 & 0.099 & 0.285 & 0.121 & 0.053 & 0.060 \\
\hline $\mathrm{Mn}(0.005)$ & 0.119 & 0.054 & 0.109 & 0.070 & 0.039 & 0.034 \\
\hline Mo $(0.02)$ & 0.010 & 0.017 & 0.039 & 0.032 & 0.025 & 0.015 \\
\hline $\mathrm{Na}(0.02)$ & 21.8 & 23.4 & 35.2 & 45.3 & 25.4 & 22.6 \\
\hline Nd $(0.03)$ & 0.026 & 0.012 & 0.008 & 0.022 & 0.003 & 0.015 \\
\hline $\mathrm{Ni}(0.03)$ & 0.025 & 0.016 & 0.012 & 0.016 & 0.012 & 0.002 \\
\hline$P(0.1)$ & 1.94 & 2.41 & 4.42 & 4.15 & 2.81 & 3.11 \\
\hline Ru $(0.05)$ & 0.003 & 0.003 & 0.000 & 0.008 & -0.005 & 0.003 \\
\hline $\mathrm{Sb}(0.05)$ & -0.020 & -0.003 & 0.010 & 0.013 & 0.000 & -0.007 \\
\hline Si $(0.02)$ & 52.5 & $52: 3$ & 61.5 & 52.8 & 50.7 & 52.4 \\
\hline Sr $(0.003)$ & 0.002 & 0.001 & 0.001 & 0.001 & 0.001 & 0.001 \\
\hline Th $(0.15)$ & 0.381 & 0.052 & 0.086 & 0.069 & 0.086 & 0.084 \\
\hline $\mathrm{Ti}(0.005)$ & 0.076 & 0.031 & 0.033 & 0.025 & 0.023 & 0.026 \\
\hline$U(0.015)$ & 0.813 & 0.383 & 0.438 & 0.462 & 0.382 & 0.334 \\
\hline$V(0.01)$ & 0.006 & 0.004 & 0.003 & 0.004 & 0.002 & 0.004 \\
\hline$Y(0.01)$ & 0.003 & 0.001 & 0.001 & 0.002 & 0.001 & 0.002 \\
\hline $\mathrm{Zn}(0.02)$ & -0.012 & -0.013 & -0.015 & -0.014 & -0.016 & -0.014 \\
\hline $\operatorname{Zr}(0.01)$ & 0.008 & 0.016 & 0.002 & 0.003 & 0.008 & 0.009 \\
\hline
\end{tabular}

(a) Numbers in parentheses are instrument detection limits.

(b) Negative numbers are the result of random variation at low concentrations. 
Table A.2. (contd)

Days of Test

Date Test Began

Date Test Ended

Specimen Wgt., g

Leachant Volume, $\mathrm{mL}$

SA/V

Specimen Mesh Size

Initial $\mathbf{p H}$

Final $\mathbf{p H}$

Total Init. Wgt., $\mathbf{g}$

Total Final Weight, $g$

Run Onder and Blind No.

Date of Analysis

Analytical Number

\section{Elements}

Al $(0.05)^{(a)}$

B $(0.01)$

Ba $(0.005)$

$\mathrm{Ca}(0.02)$

$\mathrm{Cd}(0.005)$

$\mathrm{Ce}(0.05)$

$\mathrm{Cr}(0.02)$

$\mathrm{Cu}(0.005)$

Fe (0.01)

$\mathrm{K}(0.3)$

Le $(0.01)$

Li $(0.005)$

$\mathrm{Mg}(0.06)$

Mn (0.005)

Mo $(0.02)$

Na $(0.02)$

Nd $(0.03)$

$\mathrm{Ni}(0.03)$

$P(0.1)$

$\mathrm{Ru}(0.05)$

$\mathrm{Sb}(0.05)$

Si $(0.02)$

Sr $(0.003)$

Th (0.15)

Ti $(0.005)$

$\mathrm{U}(0.015)$

$\mathrm{V}(0.01)$

$\mathrm{Y}(0.01)$

$\mathrm{Zn}(0.02)$

$Z_{5}(0.01)$

\begin{tabular}{|c|c|c|c|c|c|}
\hline WVDG-7 & WVDG-8 & WVDG-11R & WVDG-12R & WVDG-13R & WVDG-14R \\
\hline 7 & 7 & 7 & 7 & 7 & 7 \\
\hline 13-NOV-90 & 13-NOV-90 & 13-NOV-90 & 13-NOV-90 & 13-NOV-90 & 13-NOV-90 \\
\hline 20-NOV-90 & 20-NOV-90 & 20-NOV-90 & 20-NOV-90 & 20-NOV-90 & 20-NOV-90 \\
\hline 3.1478 & 3.1215 & 3.1154 & 3.2001 & 3.0556 & 3.0879 \\
\hline 31.49 & 31.21 & 31.15 & 32.00 & 30.56 & 30.88 \\
\hline 1999.2 & 2000.3 & 2000.3 & 2000.1 & 1999.7 & 1999.9 \\
\hline$-100+200$ & $-100+200$ & $-100+200$ & $-100+200$ & $-100+200$ & $-100+200$ \\
\hline 6.14 & 6.14 & 6.14 & 6.14 & 6.14 & 6.14 \\
\hline 9.41 & 9.76 & 9.75 & 9.85 & 9.57 & 9.96 \\
\hline 114.25 & 113.84 & 113.90 & 113.85 & 113.79 & 113.33 \\
\hline 113.19 & 112.74 & 111.74 & 112.90 & 112.99 & 110.89 \\
\hline $28-2$ & $49-2$ & $45-2$ & $47-2$ & $32-2$ & $33-2$ \\
\hline 12-DEC-90 & 12-DEC-90 & 12-DEC-90 & 12-DEC-90 & 12-DEC-90 & 12-DEC-90 \\
\hline $90-8008$ & $90-8029$ & $90-8025$ & $90-8027$ & $90-8012$ & $90-8013$ \\
\hline
\end{tabular}

Leachate Analyzed Concentration, mg/L

(a) Numbers in parentheses are instrument detection limits.

(b) Negative numbers are the result of random variation at low concentrations. 
Table A.2. (contd)

Days of Test

Date Test Began

Date Test Ended

Specimen Wgt., $g$

Leachant Volume, $\mathrm{mL}$

SA/V

Specimen Mesh Size

Initial pH

Final pH

Total Init. Wgt., $\mathrm{g}$

Total Final Weight, $g$

Run Order and Blind No.

Date of Analysis

Analytical Number

Elements

Al $(0.05)^{(a)}$

B $(0.01)$

Ba $(0.005)$

$\mathrm{Ca}(0.02)$

Cd (0.005)

$\mathrm{Ce}(0.05)$

Cr (0.02)

$\mathrm{Cu}(0.005)$

$\mathrm{Fe}(0.01)$

$\mathrm{K}(0.3)$

La (0.01)

Li $(0.005)$

$\mathrm{Mg}(0.06)$

$\mathrm{Mn}(0.005)$

Mo $(0.02)$

$\mathrm{Na}(0.02)$

Nd (0.03)

Ni $(0.03)$

P $(0.1)$

Ru (0.05)

$\mathrm{Sb}(0.05)$

Si (0.02)

Sr $(0.003)$

Th $(0.15)$

Ti $(0.005)$

U $(0.015)$

$\mathrm{V}(0.01)$

Y $(0.01)$

Zn (0.02)

$\mathrm{Zr}(0.01)$

.

\begin{tabular}{|c|c|c|c|c|c|}
\hline WVDG-15 & WVDG-16 & WVDG-17 & WVDG-18 & WVDG-19 & WVDG-20 \\
\hline 7 & 7 & 7 & 7 & 7 & 7 \\
\hline 13-NOV-90 & 13-NOV-90 & 12-NOV-90 & $12-N O V-90$ & $12-N O V-90$ & $12-N O V-90$ \\
\hline 20-NOV-90 & $20-N O V-90$ & 19-NOV-90 & 19-NOV-90 & 19-NOV-90 & 19-NOV-90 \\
\hline 3.1308 & 3.2050 & 3.0640 & 3.0939 & 3.1833 & 3.0756 \\
\hline 31.30 & 32.05 & 30.64 & 30.94 & 31.84 & 30.76 \\
\hline 2000.5 & 2000.0 & 2000.000 & 1999.935 & 1999.560 & 1999.740 \\
\hline$-100+200$ & $-100+200$ & $-100+200$ & $-100+200$ & $-100+200$ & $-100+200$ \\
\hline 6.14 & 6.14 & 6.14 & 6.14 & 6.14 & 6.14 \\
\hline 9.99 & 9.44 & 10.08 & 9.98 & 9.70 & 9.48 \\
\hline 113.41 & 113.83 & 113.08 & 113.55 & 114.75 & 113.60 \\
\hline 111.93 & 113.30 & 112.90 & 111.98 & 113.10 & 112.87 \\
\hline $41-2$ & $44-2$ & $3-2$ & $15-2$ & $4-2$ & $25-2$ \\
\hline 12-DEC-90 & $12-D E C-90$ & $12-D E C-90$ & 12-DEC-90 & $12-\mathrm{DEC}-90$ & 12-DEC-90 \\
\hline $90-8021$ & $90-8024$ & $90-7983$ & $90-7995$ & $90-7984$ & $90-8005$ \\
\hline
\end{tabular}

Leachate Analyzed Concentration, $\mathrm{mg} / \mathrm{L}$

\begin{tabular}{|c|c|c|c|c|c|}
\hline 11.0 & 10.1 & 11.1 & 13.0 & 16.0 & 14.2 \\
\hline 23.2 & 13.9 & 18.1 & 14.7 & 12.8 & 10.1 \\
\hline 0.003 & 0.006 & 0.002 & 0.007 & 0.005 & 0.012 \\
\hline 0.018 & 0.044 & 0.037 & 0.059 & 0.059 & 0.068 \\
\hline$-0.000^{(b)}$ & -0.002 & -0.000 & -0.001 & 0.000 & 0.000 \\
\hline 0.004 & 0.014 & 0.037 & 0.033 & 0.026 & 0.070 \\
\hline 0.029 & 0.002 & 0.036 & 0.000 & -0.000 & 0.009 \\
\hline 0.003 & -0.000 & 0.008 & 0.001 & 0.001 & 0.004 \\
\hline 0.398 & 0.342 & 0.301 & 1.58 & 0.396 & 0.359 \\
\hline 2.60 & 1.88 & 5.13 & 3.45 & 4.22 & 3.34 \\
\hline-0.001 & 0.001 & 0.004 & 0.001 & 0.003 & 0.009 \\
\hline 7.66 & 3.79 & 6.50 & 6.11 & 5.18 & 4.37 \\
\hline 0.147 & 0.044 & 0.114 & 0.014 & 0.113 & 0.089 \\
\hline 0.119 & 0.054 & 0.085 & 0.043 & 0.015 & 0.017 \\
\hline 0.235 & 0.033 & 0.271 & 0.040 & 0.053 & 0.118 \\
\hline 40.2 & 19.9 & 44.0 & 36.1 & 29.2 & 17.3 \\
\hline-0.013 & -0.002 & 0.016 & 0.008 & 0.011 & 0.025 \\
\hline 0.016 & -0.006 & 0.021 & 0.015 & -0.003 & -0.003 \\
\hline 2.81 & 2.45 & 2.93 & 2.36 & 2.03 & 1.75 \\
\hline-0.008 & -0.002 & 0.003 & -0.009 & 0.001 & 0.010 \\
\hline-0.009 & -0.004 & -0.002 & -0.025 & -0.007 & 0.015 \\
\hline 48.9 & 42.1 & 48.3 & 55.1 & 41.1 & 41.3 \\
\hline 0.001 & 0.001 & 0.001 & 0.001 & 0.001 & 0.002 \\
\hline 0.024 & 0.034 & 0.027 & 0.194 & 0.038 & 0.080 \\
\hline 0.016 & 0.006 & 0.013 & 0.031 & 0.007 & 0.050 \\
\hline 0.528 & 0.076 & 1.19 & 0.105 & 1.577 & 0.068 \\
\hline 0.000 & 0.002 & 0.004 & 0.003 & 0.004 & 0.004 \\
\hline 0.000 & 0.000 & 0.001 & 0.001 & 0.001 & 0.003 \\
\hline-0.007 & -0.012 & -0.008 & -0.008 & -0.015 & -0.012 \\
\hline-0.003 & 0.003 & 0.005 & 0.006 & 0.004 & 0.008 \\
\hline
\end{tabular}

(a) Numbers in parentheses are instrument detection limits.

(b) Negative numbers are the result of random variation at low concentrations. 
Table A.2. (contd)

Days of Test

Date Test Began

Date Test Ended

Specimen Wgt., g

Leachant Volume, $\mathrm{mL}$

SA/V

Specimen Mesh Size

WVDG-21
7
12-NOV-90
19-NOV-90

WVDG-22

7

12-NOV-9O

19-NOV-90

WVDG-23

WVDG-24

WVDG-25

WVDG-26

$7 \quad 7$

12-NOV-90

7

13-NOV-90

7

7

19-NOV-90

20-NOV-90

12-NOV-90

13-NOV-90

3.3066

3.1245

3.2029

3.0444

20-NOV-90

33.06

31.24

32.02

2000.6

$-100+200$

2000.320

$-100+200$

30.45

1999.6

$-100+200$

3.0614

1999.0

32.25

$-100+200$

6.14

6.14

$-100+200$

2000.0

Initial $\mathrm{pH}$

6.14

6.14

9.40

9.44

6.14

9.66

6.14

112.26

113.10

115.30

113.33

113.08

9.53

Total lnit. Wgt., g

111.79

112.23

114.39

111.93

112.31

113.00

Run Order and Blind No.

9-2

Date of Analysis

Analytical Number

12-DEC-90

13-2

20-2

38-2.

12-DEC-90

12-DEC-90

12-DEC-90

7-2

111.96

90-7989

90-7993

90-8000

90-8018

37-2

90-7987 12-DEC

Leachate Analyzed Concentration, $\mathrm{mg} / \mathrm{L}$

\begin{tabular}{|c|c|c|c|c|c|c|}
\hline Al $(0.05)^{(a)}$ & 21.0 & 18.6 & 13.4 & 15.4 & 12.1 & 13.5 \\
\hline $\mathrm{B}(0.01)$ & 14.0 & 14.5 & 18.9 & 16.3 & 12.4 & 15.5 \\
\hline $\mathrm{Ba}(0.005)$ & 0.009 & 0.004 & 0.020 & 0.005 & 0.005 & 0.011 \\
\hline $\mathrm{Ca}(0.02)$ & 0.075 & 0.043 & 0.114 & 0.039 & 0.044 & 0.063 \\
\hline $\mathrm{Cd}(0.005)$ & 0.000 & 0.001 & $-0.000^{(b)}$ & 0.000 & 0.000 & -0.001 \\
\hline $\mathrm{Ce}(0.05)$ & 0.059 & 0.123 & 0.140 & 0.026 & 0.048 & 0.011 \\
\hline $\operatorname{Cr}(0.02)$ & 0.007 & -0.004 & 0.021 & 0.000 & 0.008 & 0.000 \\
\hline $\mathrm{Cu}(0.005)$ & 0.004 & 0.008 & 0.015 & 0.001 & 0.005 & 0.001 \\
\hline$F e(0.01)$ & 1.90 & 0.559 & 4.62 & 0.712 & 1.03 & 0.782 \\
\hline K $(0.3)$ & 3.92 & 2.38 & 2.45 & 2.37 & 3.31 & 1.79 \\
\hline La $(0.01)$ & 0.003 & 0.008 & 0.013 & 0.002 & 0.006 & 0.001 \\
\hline Li $(0.005)$ & 5.41 & 4.91 & 4.90 & 4.96 & 4.68 & 4.78 \\
\hline $\mathrm{Mg}(0.06)$ & 0.059 & 0.022 & 0.082 & 0.024 & 0.033 & 0.114 \\
\hline $\mathrm{Mn}(0.005)$ & 0.256 & 0.127 & 0.106 & 0.043 & 0.153 & 0.039 \\
\hline Mo $(0.02)$ & 0.039 & 0.150 & 0.033 & 0.034 & 0.037 & 0.037 \\
\hline $\mathrm{Na}(0.02)$ & 34.4 & 21.3 & 22.1 & 23.4 & 21.8 & 21.2 \\
\hline Nd $(0.03)$ & 0.008 & 0.026 & 0.049 & 0.005 & 0.020 & -0.007 \\
\hline $\mathrm{Ni}(0.03)$ & 0.002 & -0.001 & 0.011 & 0.006 & 0.011 & 0.012 \\
\hline$P(0.1)$ & 4.13 & 1.29 & 5.59 & 1.79 & 2.51 & 1.45 \\
\hline$R u(0.05)$ & -0.003 & -0.001 & 0.006 & -0.008 & 0.009 & -0.004 \\
\hline $\mathrm{Sb}(0.05)$ & -0.019 & -0.026 & 0.002 & -0.019 & 0.004 & -0.013 \\
\hline si $(0.02)$ & 53.8 & 49.2 & 52.0 & 48.1 & 53.5 & 41.3 \\
\hline Sr $(0.003)$ & 0.001 & 0.002 & 0.003 & 0.001 & 0.001 & 0.001 \\
\hline Th $(0.15)$ & 0.457 & 0.255 & 2.21 & 0.108 & 0.371 & 0.153 \\
\hline $\mathrm{TI}(0.005)$ & 0.050 & 0.063 & 0.125 & 0.024 & 0.034 & 0.016 \\
\hline $\mathrm{U}(0.015)$ & 1.29 & 0.093 & 1.04 & 0.798 & 0.073 & 0.078 \\
\hline $\mathrm{V}(0.01)$ & 0.004 & 0.004 & 0.018 & 0.001 & 0.006 & 0.001 \\
\hline$Y(0.01)$ & 0.002 & 0.004 & 0.005 & 0.000 & 0.002 & 0.000 \\
\hline $\mathrm{Zn}(0.02)$ & -0.015 & -0.010 & -0.011 & -0.014 & -0.010 & -0.011 \\
\hline $\operatorname{Zr}(0.01)$ & 0.001 & 0.012 & 0.015 & 0.008 & 0.008 & 0.005 \\
\hline
\end{tabular}

(a) Numbers in parentheses are instrument detection limits.

(b) Negative numbers are the result of random variation at low concentrations. 
Table A.2. (contd)

Days of Test

Date Test Began

Date Test Ended

\begin{tabular}{|c|c|c|c|c|c|c|c|}
\hline WVDG-27 & WVDG-28 & WVDG-29 & WVDG-30 & WVDG-31B & WVDG-31C & WVDG-33 & WVDG-34 \\
\hline 7 & 7 & 7 & 7 & 7 & 7 & 7 & 7 \\
\hline 13-NOV-90 & 13-NOV-90 & 13-NOV-90 & 12-NOV-90 & 12-NOV-9 & 13-NOV-9 & 12-NOV-90 & 12-NOV-90 \\
\hline 20-NOV-90 & 20-NOV-90 & 20-NOV-90 & 19-NOV-90 & 19-NOV-9 & 20-NOV-9 & 19-NOV-90 & 19-NOV-90 \\
\hline 3.0853 & 3.0948 & 3.2008 & 3.0419 & 3.0158 & 3.0464 & 2.9952 & 3.0518 \\
\hline 30.85 & 30.95 & 32.02 & 30.42 & 30.17 & 30.46 & 29.94 & 30.52 \\
\hline 2000.2 & 2000.0 & 1999.3 & 1999.9 & 1999.2 & 2000.3 & 2000.8 & 1999.9 \\
\hline$-100+200$ & $-100+200$ & $-100+200$ & $-100+200$ & $-100+200$ & $-100+200$ & $-100+200$ & $-100+200$ \\
\hline 6.14 & 6.14 & 6.14 & 6.14 & 6.14 & 6.14 & 6.14 & 6.14 \\
\hline 9.59 & 9.51 & 9.78 & 9.66 & 9.83 & 9.86 & 10.23 & 10.15 \\
\hline 113.55 & 113.47 & 115.18 & 112.78 & 112.54 & 111.95 & 112.93 & 112.88 \\
\hline 108.74 & 111.21 & 113.28 & 111.39 & 112.13 & 110.57 & 112.03 & 110.08 \\
\hline $31-2$ & $39-2$ & $50-2$ & $24-2$ & $17-2$ & $40-2$ & $12-2$ & $1-2$ \\
\hline 12-DEC-90 & 12-DEC-90 & 12-DEC-90 & 12-DEC-90 & 12-DEC-90 & 12-DEC-90 & 12-DEC-90 & 12-DEC-90 \\
\hline $90-8011$ & $90-8019$ & $90-8030$ & $90-8004$ & $90-7997$ & $90-8020$ & $90-7992$ & $90-7981$ \\
\hline
\end{tabular}

Date of Analysis

90-801

Leachate Analyzed Concentration, $\mathrm{mg} / \mathrm{L}$

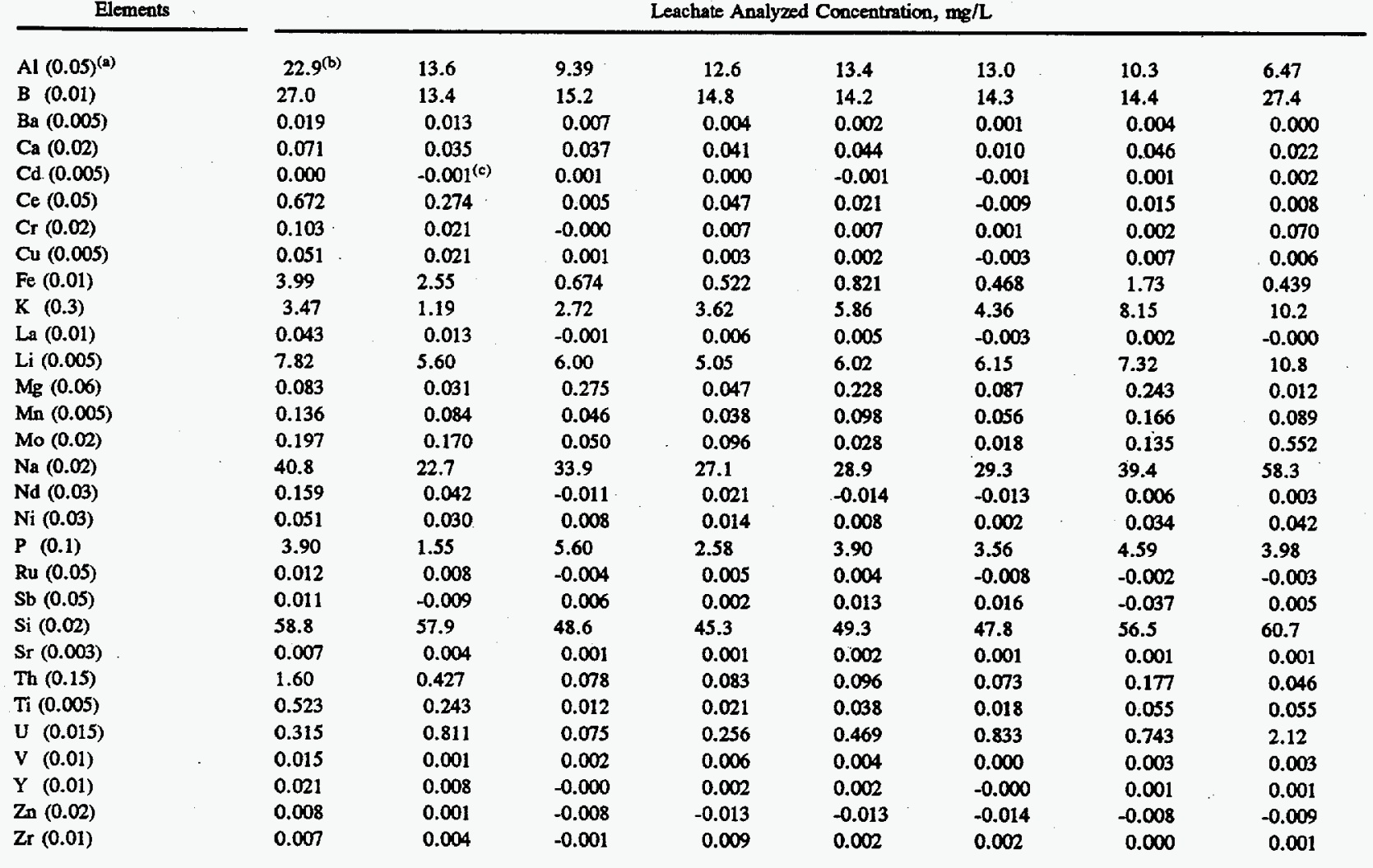

(a) Numbers in parentheses are instrument detection limits.

(b) Data excluded from calculations because of leachant loss $>10 \%$.

(c) Negative numbers are the result of random variation at low concentrations. 
Table A.2. (contd)

Days of Test

Date Test Began

Date Test Ended

WVDG-35
7
12-NOV-90
19-NOV-90

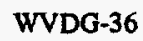

Specimen Wgt., $g$

3.2360
32.37

Leachant Volume, $\mathrm{mL}$ SAIV

1999.4

Specimen Mesh Size

$-100+200$

30.16

1993.6

6.14

10.61

6.14

Final pH

115.90

Total Init. Wgt., g

Total Final Weight, $g$

114.83

22-2

Run Order and Blind No.

Date of Analysis

Analytical Number

\section{2-DEC-90}

90-8002

9.94

WVDG-37
7
$12-N O V-90$
$19-N O V-90$

WVDG-38

WVDG-39

7

7

7

13-NOV-90 13-NOV-90

20-NOV-90 20-NOV-90 20-NOV-90

$\begin{array}{ll}13-N O V-90 & 12-N O V-90 \\ 20-N O V-90 & 19-N O V-90\end{array}$

3.2320

3.0882

3.0830

3.0301

32.32

2000.0

30.88

1999.4

2000.7

$-100+200$

$-100+200$

6.14

9.99

6.14

10.24

9.99

9.81

112.97

114.67

113.73

113.70

112.20

113.51

112.14

43-2

12-DEC-90

90-8023

6-2-DEC-90 $29-2$

29-2

12-DEC-90

26-2

34-2

90-7986.

90-8009

12-DEC-90

90-8006

12-DEC-90

90-8014

Elements

\begin{tabular}{l} 
Al $(0.05)^{(a)}$ \\
B $(0.01)$ \\
Ba $(0.005)$ \\
Ca $(0.02)$ \\
Cd $(0.005)$ \\
Ce $(0.05)$ \\
Cr $(0.02)$ \\
Cu $(0.005)$ \\
Fe $(0.01)$ \\
K $(0.3)$ \\
La $(0.01)$ \\
Li $(0.005)$ \\
Mg $(0.06)$ \\
Mn $(0.005)$ \\
Mo $(0.02)$ \\
Na $(0.02)$ \\
Nd $(0.03)$ \\
Ni $(0.03)$ \\
P $(0.1)$ \\
Ru $(0.05)$ \\
Sb $(0.05)$ \\
Si $(0.02)$ \\
Sr $(0.003)$ \\
Th $(0.15)$ \\
Ti $(0.005)$ \\
U (0.015) \\
V (0.01) \\
Y (0.01) \\
Zn $(0.02)$ \\
Zr $(0.01)$ \\
\hline \\
\hline
\end{tabular}

Leachate Analyzed Concentration, $\mathrm{mg} / \mathrm{L}$

\begin{tabular}{lccccc}
\hline 18.9 & 6.54 & 15.7 & 14.6 & 12.3 & 6.09 \\
17.6 & 16.3 & 10.8 & 9.34 & 17.7 & 14.5 \\
0.005 & 0.001 & 0.004 & 0.002 & 0.002 & 0.004 \\
0.042 & 0.006 & 0.058 & 0.025 & 0.231 & 0.037 \\
0.001 & -0.000 (b) & 0.002 & 0.001 & 0.001 & 0.001 \\
0.008 & 0.039 & 0.070 & 0.068 & 0.037 & 0.047 \\
0.002 & 0.002 & 0.049 & 0.033 & 0.003 & 0.004 \\
0.001 & 0.010 & 0.041 & 0.016 & 0.004 & 0.006 \\
2.61 & 0.640 & 1.82 & 0.793 & 0.499 & 1.10 \\
12.9 & 5.05 & 9.16 & 7.36 & 9.37 & 10.3 \\
0.001 & 0.010 & 0.016 & 0.015 & 0.007 & 0.011 \\
11.4 & 5.04 & 7.97 & 6.17 & 6.58 & 7.66 \\
0.394 & 0.017 & 0.057 & 0.035 & 0.231 & 0.319 \\
0.241 & 0.003 & 0.017 & 0.119 & 0.005 & 0.006 \\
0.086 & 0.359 & 0.408 & 0.377 & 0.073 & 0.084 \\
66.1 & 11.7 & 46.1 & 29.4 & 37.9 & 42.0 \\
0.002 & 0.026 & 0.051 & 0.059 & 0.026 & 0.041 \\
-0.004 & -0.006 & 0.138 & 0.022 & 0.004 & 0.006 \\
1.49 & 0.667 & 0.859 & 0.804 & 6.63 & 1.22 \\
-0.000 & 0.004 & 0.002 & 0.013 & 0.010 & 0.016 \\
-0.009 & -0.008 & 0.010 & 0.009 & 0.011 & 0.024 \\
64.5 & 51.5 & 58.0 & 51.6 & 43.3 & 64.9 \\
0.001 & 0.002 & 0.006 & 0.003 & 0.002 & 0.001 \\
0.063 & 0.299 & 0.310 & 0.222 & 0.090 & 0.049 \\
0.013 & 0.087 & 0.303 & 0.143 & 0.010 & 0.008 \\
2.16 & 0.089 & 0.080 & 0.035 & 0.062 & 2.74 \\
0.005 & 0.006 & 0.005 & 0.008 & 0.005 & 0.009 \\
0.000 & 0.004 & 0.007 & 0.006 & 0.002 & 0.003 \\
-0.024 & -0.008 & 0.013 & -0.005 & 0.013 & -0.023 \\
0.001 & 0.032 & 0.037 & 0.038 & 0.003 & 0.005 \\
& & & & &
\end{tabular}

(a) Numbers in parentheses are instrument detection limits.

(b) Negative numbers are the result of random variation at low concentrations. 
Table A.2. (contd)

Days of Test

Date Test Began

Date Test Ended

Specimen Wgt., g

Leachant Volume, $\mathrm{mL}$

SA/V

Specimen Mesh Size

Initial $\mathrm{pH}$

Final pH

Total Init. Wgt., $g$

Total Final Weight, $g$

Run Order and Blind No.

Date of Analysis

Analytical Number

\begin{tabular}{|c|c|c|c|c|c|}
\hline WVDG-41 & WVDG-42 & WVDG-43 & WVDG-44 & WVDG-45 & WVDG-46 \\
\hline 7 & 7 & 7 & 7 & 7 & 7 \\
\hline 12-NOV-90 & 12-NOV-90 & 13-NOV-90 & 13-NOV-90 & 12-NOV-90 & 13-NOV-90 \\
\hline 19-NOV-90 & 19-NOV-90 & 20-NOV-90 & 20-NOV-90 & 19-NOV-90 & 20-NOV-90 \\
\hline 3.0677 & 3.0772 & 3.0388 & 3.0369 & 3.2642 & 3.1433 \\
\hline 30.69 & 30.77 & 30.40 & 30.36 & 32.64 & 31.43 \\
\hline 1999.2 & 2000.1 & 1999.2 & 2000.6 & 2000.1 & 2000.2 \\
\hline$-100+200$ & $-100+200$ & $-100+200$ & $-100+200$ & $-100+200$ & $-100+200$ \\
\hline 6.14 & 6.14 & 6.14 & 6.14 & 6.14 & 6.14 \\
\hline 10.54 & 10.50 & 9.44 & 10.22 & 10.60 & 10.02 \\
\hline 114.00 & 114.06 & 112.72 & 113.15 & 115.76 & 114.40 \\
\hline 112.66 & 113.74 & 111.67 & 110.57 & 114.90 & 112.69 \\
\hline $19-2$ & $8-2$ & $36-2$ & $46-2$ & $21-2$ & $30-2$ \\
\hline 12-DEC-90 & 12-DEC-90 & 12-DEC-90 & 12-DEC-90 & 12-DEC-90 & 12-DEC-90 \\
\hline $90-7999$ & $90-7988$ & $90-8016$ & $90-8026$ & $90-8001$ & $90-9010$ \\
\hline
\end{tabular}

Elements

(a)

Al $(0.05)^{(a)}$

B $(0.01)$

$\mathrm{Ba}(0.005)$

$\mathrm{Ca}(0.02)$

Cd $(0.005)$

$\mathrm{Ce}(0.05)$

Cr $(0.02)$

$\mathrm{Cu}(0.005)$

Fe $(0.01)$

K (0.3)

La $(0.01)$

Li $(0.005)$

Mg (0.06)

Mn (0.005)

Mo $(0.02)$

$\mathrm{Na}(0.02)$

Nd (0.03)

$\mathrm{Ni}(0.03)$

P $(0.1)$

Ru (0.05)

Sb (0.05)

Si $(0.02)$

Sr $(0.003)$

Th (0.15)

Ti $(0.005)$

U $(0.015)$

V $(0.01)$

Y $(0.01)$

Zn (0.02)

$\mathrm{Zr}(0.01)$

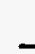

Leachate Analyzed Concentration, mg/L

\begin{tabular}{|c|c|c|c|c|c|}
\hline 7.92 & 4.71 & 14.4 & 12.2 & 17.6 & 8.31 \\
\hline 14.1 & 15.1 & 15.5 & 25.9 & 12.1 & 30.5 \\
\hline 0.002 & 0.003 & 0.008 & 0.001 & 0.002 & 0.005 \\
\hline 0.036 & 0.085 & 0.050 & 0.006 & 0.035 & 0.063 \\
\hline 0.001 & 0.000 & $-0.002^{(b)}$ & 0.000 & -0.001 & 0.000 \\
\hline 0.017 & 0.016 & 0.045 & 0.012 & 0.030 & 0.033 \\
\hline 0.001 & 0.015 & 0.021 & 0.004 & 0.013 & 0.006 \\
\hline 0.006 & 0.022 & 0.020 & 0.002 & 0.009 & 0.013 \\
\hline 1.50 & 1.19 & 5.18 & 0.917 & 2.28 & 1.69 \\
\hline 10.4 & 11.8 & 3.91 & 8.11 & 10.7 & 9.13 \\
\hline 0.003 & 0.002 & 0.011 & 0.002 & 0.005 & 0.005 \\
\hline 8.81 & 9.08 & 5.23 & 10.2 & 8.29 & 9.00 \\
\hline 0.056 & 0.363 & 0.068 & 0.023 & 0.031 & 0.527 \\
\hline 0.013 & 0.196 & 0.555 & 0.006 & 0.241 & 0.292 \\
\hline 0.072 & 0.682 & 0.029 & 0.062 & 0.096 & 0.067 \\
\hline 62.5 & 53.7 & 16.5 & 54.1 & 54.1 & 48.9 \\
\hline 0.008 & 0.013 & 0.032 & -0.003 & 0.019 & 0.018 \\
\hline 0.018 & 0.071 & 0.029 & 0.004 & 0.009 & 0.011 \\
\hline 10.1 & 10.6 & 1.97 & 0.947 & 9.47 & 1.11 \\
\hline 0.005 & 0.004 & -0.005 & -0.003 & 0.001 & 0.011 \\
\hline-0.009 & -0.011 & -0.008 & -0.003 & -0.012 & 0.016 \\
\hline 68.3 & 61.4 & 54.5 & 52.2 & 57.1 & 62.7 \\
\hline 0.001 & 0.002 & 0.003 & 0.001 & 0.001 & 0.001 \\
\hline 0.392 & 0.082 & 1.82 & 0.168 & 0.229 & 0.213 \\
\hline 0.025 & 0.071 & 0.137 & 0.014 & 0.054 & 0.025 \\
\hline 3.41 & 0.057 & 0.721 & 3.03 & 0.072 & 0.138 \\
\hline 0.005 & 0.005 & 0.013 & 0.003 & 0.006 & 0.007 \\
\hline 0.002 & 0.002 & 0.004 & 0.000 & 0.001 & 0.001 \\
\hline-0.022 & 0.005 & -0.012 & -0.019 & -0.010 & -0.002 \\
\hline 0.001 & 0.003 & 0.012 & 0.002 & 0.001 & 0.003 \\
\hline
\end{tabular}

(a) Numbers in parentheses are instrument detection limits.

(b) Negative numbers are the result of random variation at low concentrations. 
Table A.2. (contd)

\begin{tabular}{|c|c|c|c|c|c|c|}
\hline & WVDG-47 & WVDG -48 & $\begin{array}{l}\text { WVDG-49 } \\
\text { (ARM-1) }\end{array}$ & $\begin{array}{l}\text { WVDG-50 } \\
\text { (ARM-1) }\end{array}$ & $\begin{array}{l}\text { WVDG-51 } \\
\text { Blank }\end{array}$ & $\begin{array}{l}\text { WVDG-52 } \\
\text { Blank }\end{array}$ \\
\hline Days of Test & 7 & 7 & 7 & 7 & 7 & 7 \\
\hline Date Test Began & 12-NOV-90 & 13-NOV-90 & 12-NOV-90 & 13-NOV-90 & $12-N O V-90$ & 13-NOV-90 \\
\hline Date Test Ended & 19-NOV-90 & 20-NOV-90 & 19-NOV-90 & 20-NOV-90 & 19-NOV-90 & 20-NOV-90 \\
\hline Specimen Wgt., g & 3.0404 & 3.0757 & 3.1006 & 3.1178 & no specimen & no specimen \\
\hline Leachant Volume, $\mathrm{mL}$ & 30.39 & 30.77 & 31.02 & 31.17 & 31.76 & 27.93 \\
\hline SA/V & 2000.9 & 1999.2 & 1999.1 & 2000.5 & & \\
\hline Specimen Mesh Size & $-100+200$ & $-100+200$ & $-100+200$ & $-100+200$ & $-100+200$ & $-100+200$ \\
\hline Initial pH & 6.14 & 6.14 & 6.14 & 6.14 & 6.14 & 6.14 \\
\hline Final pH & 9.32 & 9.35 & 10.42 & 10.45 & 8.40 & 8.14 \\
\hline Total Init. Wgt., g & 112.32 & 113.73 & 113.38 & 113.76 & 111.52 & 107.44 \\
\hline Total Final Weight, $g$ & 111.01 & 112.02 & 112.57 & 112.27 & 111.31 & 107.27 \\
\hline Run Order and Blind No. & $16-2$ & $48-2$ & $23-2$ & $35-2$ & $14-2$ & $42-2$ \\
\hline Date of Analysis & 12-DEC-90 & 12-DEC-90 & 12-DEC-90 & 12-DEC-90 & 12-DEC-90 & 12-DEC-90 \\
\hline Analytical Number & $0-=7996$ & $90-8028$ & $90-8003$ & $90-8015$ & $90-7994$ & $90-8022$ \\
\hline Elements & \multicolumn{6}{|c|}{ Leachate Analyzed Concentration, $\mathrm{mg} / \mathrm{L}$} \\
\hline Al $(0.05)^{(a)}$ & 7.35 & 12.1 & 4.11 & 4.44 & $-0.003^{(b)}$ & -0.003 \\
\hline $\mathrm{B}(0.01)$ & 15.3 & 11.4 & 16.8 & 17.3 & 0.053 & 0.063 \\
\hline $\mathrm{Ba}(0.005)$ & 0.005 & 0.005 & 0.004 & 0.009 & 0.000 & 0.001 \\
\hline $\mathrm{Ca}(0.02)$ & 0.051 & 0.044 & 0.217 & 0.231 & 0.028 & 0.004 \\
\hline $\mathrm{Cd}(0.005)$ & 0.001 & 0.000 & -0.001 & 0.001 & -0.003 & -0.002 \\
\hline $\mathrm{Ce}(0.05)$ & 0.045 & 0.028 & 0.015 & 0.075 & 0.014 & -0.014 \\
\hline $\operatorname{Cr}(0.02)$ & 0.015 & 0.002 & -0.002 & -0.002 & -0.005 & -0.002 \\
\hline $\mathrm{Cu}(0.005)$ & 0.016 & 0.013 & 0.009 & 0.007 & -0.001 & -0.000 \\
\hline $\mathrm{Fe}(0.01)$ & 5.86 & 0.344 & -0.035 & -0.033 & -0.040 & -0.022 \\
\hline K $(0.3)$ & 5.14 & 3.79 & -0.262 & 1.86 & -0.159 & -1.34 \\
\hline La $(0.01)$ & 0.010 & 0.006 & 0.002 & 0.012 & 0.000 & -0.002 \\
\hline Li $(0.005)$ & 4.80 & 4.23 & 13.3 & 14.1 & 0.005 & 0.006 \\
\hline $\mathrm{Mg}(0.06)$ & 0.062 & 0.058 & 0.025 & 0.066 & -0.002 & -0.009 \\
\hline $\operatorname{Mn}(0.005)$ & 0.524 & 0.005 & 0.001 & 0.001 & -0.001 & 0.002 \\
\hline Mo $(0.02)$ & 0.034 & 0.247 & 5.420 & 5.615 & -0.014 & -0.005 \\
\hline $\mathrm{Na}_{\mathrm{a}}(0.02)$ & 19.9 & 15.3 & 35.9 & 37.6 & 0.026 & 0.029 \\
\hline $\mathrm{Nd}(0.03)$ & 0.034 & 0.012 & 0.030 & 0.128 & -0.000 & -0.015 \\
\hline $\mathrm{Ni}(0.03)$ & 0.016 & 0.001 & -0.004 & -0.003 & -0.008 & -0.008 \\
\hline$P(0.1)$ & 4.79 & 2.45 & 0.927 & 0.917 & 0.015 & 0.006 \\
\hline$R u(0.05)$ & 0.001 & -0.001 & 0.003 & 0.019 & -0.005 & -0.008 \\
\hline $\mathrm{Sb}(0.05)$ & -0.017 & 0.005 & 0.007 & 0.027 & -0.025 & -0.021 \\
\hline $\mathrm{Si}(0.02)$ & 59.1 & 42.4 & 59.6 & 62.4 & 0.003 & 0.045 \\
\hline Sr $(0.003)$ & 0.003 & 0.002 & 0.020 & 0.024 & 0.000 & 0.000 \\
\hline Th $(0.15)$ & 0.879 & 0.115 & 0.005 & -0.002 & -0.001 & -0.010 \\
\hline Ti $(0.005)$ & 0.108 & 0.073 & 0.011 & 0.042 & 0.000 & 0.000 \\
\hline$U(0.015)$ & 0.237 & 0.233 & & & & \\
\hline$V(0.01)$ & 0.010 & 0.001 & 0.008 & 0.014 & -0.000 & -0.003 \\
\hline$Y(0.01)$ & 0.004 & 0.003 & -0.000 & 0.003 & 0.000 & -0.002 \\
\hline $\mathrm{Zn}(0.02)$ & -0.007 & -0.007 & 0.028 & 0.063 & -0.014 & -0.010 \\
\hline $\operatorname{Zr}(0.01)$ & 0.004 & 0.006 & 0.011 & 0.031 & -0.001 & -0.004 \\
\hline
\end{tabular}

(a) Numbers in parentheses are instrument detection limits.

(b) Negative numbers are the result of random variation at low concentrations. 
Table A.3. Test Information and Leachate ICP and XRF Results for Third Series of PCT Tests of West Valley Compositional Variability Glasses

\begin{tabular}{|c|c|c|c|c|c|c|}
\hline & WVDG-1 & WVDG-2 & WVDG-3 & WVDG-4 & WVDG-5 & WVDG-6 \\
\hline Days of Test & 7 & 7 & 7 & 7 & 7 & 7 \\
\hline Date Test Began & 27-NOV-90 & 27-NOV-90 & 27-NOV-90 & 26-NOV-90 & 27-NOV-90 & 27-NOV-90 \\
\hline Date Test Ended & 04-DEC-90 & 04-DEC-90 & 04-DEC-90 & 03-DEC-90 & 04-DEC-90 & 04-DEC-90 \\
\hline Specimen Wgt., g & 3.0029 & 3.7657 & 4.0075 & 4.0919 & 3.8760 & 3.7881 \\
\hline Leachant Volume, $\mathrm{mL}$ & 30.01 & 37.66 & 40.07 & 40.90 & 38.78 & 37.87 \\
\hline SA/V & 2001.3 & 1999.8 & 2000.2 & 2000.9 & 1999.0 & 2000.6 \\
\hline Specimen Mesh Size & $-100+200$ & $-100+200$ & $-100+200$ & $-100+200$ & $-100+200$ & $-100+200$ \\
\hline Initial $\mathbf{p H}$ & 6.44 & 6.44 & 6.44 & 6.44 & 6.44 & 6.44 \\
\hline Final pH & 9.47 & 9.37 & 9.90 & 9.92 & 9.52 & 9.53 \\
\hline Total Init. Wgt., g & 112.22 & 119.42 & 122.98 & 124.38 & 122.41 & 120.91 \\
\hline Total Final Weight, $\mathrm{g}$ & 110.26 & .116 .73 & 122.55 & 123.88 & 122.47 & 118.90 \\
\hline Run Order and Blind No. & $43-3$ & $32-3$ & $42-3$ & $5-3$ & $39-3$ & $50-3$ \\
\hline Date of Analysis & 20-DEC-90 & 20-DEC-90 & 20-DEC-90 & 20-DEC-90 & 20-DEC-90 & 20-DEC-90 \\
\hline Analytical Number & $90-8074$ & $90-8063$ & $90-8073$ & $90-8036$ & $90-8070$ & $90-8080$ \\
\hline Elements & \multicolumn{6}{|c|}{ Leachate Analyzed Concentration, $\mathrm{mg} / \mathrm{L}$} \\
\hline Al $(0.05)^{(a)}$ & 10.2 & 10.5 & 7.03 & 9.84 & 6.65 & 10.4 \\
\hline B $(0.01)$ & 13.6 & 16.3 & 13.8 & 18.8 & 16.2 & 14.9 \\
\hline $\mathrm{Ba}(0.005)$ & 0.002 & 0.002 & 0.001 & 0.001 & 0.001 & 0.001 \\
\hline $\mathrm{Ca}(0.02)$ & 0.019 & 0.011 & 0.003 & $-0.049^{(b)}$ & 0.007 & 0.002 \\
\hline $\mathrm{Cd}(0.005)$ & 0.001 & 0.001 & -0.001 & -0.001 & -0.001 & -0.002 \\
\hline $\mathrm{Ce}(0.05)$ & 0.002 & 0.016 & -0.001 & 0.007 & -0.005 & -0.009 \\
\hline $\operatorname{Cr}(0.02)$ & 0.007 & 0.005 & 0.010 & 0.004 & 0.002 & 0.003 \\
\hline $\mathrm{Cu}(0.005)$ & 0.000 & 0.001 & 0.001 & -0.002 & 0.006 & 0.001 \\
\hline $\mathrm{Fe}(0.01)$ & 0.861 & 0.820 & 0.723 & 0.594 & 0.486 & 0.646 \\
\hline K $(0.3)$ & 1.56 & 1.90 & 2.55 & 1.55 & 1.61 & 0.720 \\
\hline $\mathrm{La}(0.01)$ & -0.001 & 0.004 & -0.011 & 0.001 & -0.001 & -0.004 \\
\hline $\mathrm{Li}(0.005)$ & 4.02 & 5.35 & 6.19 & 4.64 & 4.58 & 4.69 \\
\hline $\mathrm{Mg}(0.06)$ & 0.082 & 0.086 & 0.234 & 0.100 & 0.046 & 0.020 \\
\hline $\operatorname{Mn}(0.005)$ & 0.071 & 0.067 & 0.091 & 0.058 & 0.037 & 0.043 \\
\hline Mo $(0.02)$ & 0.021 & 0.022 & 0.040 & 0.028 & 0.020 & 0.022 \\
\hline $\mathrm{Na}(0.02)$ & 21.7 & 25.4 & 33.3 & 44.0 & 26.5 & 22.7 \\
\hline Nd $(0.03)$ & 0.020 & 0.010 & 0.014 & 0.008 & 0.012 & 0.014 \\
\hline $\mathrm{Ni}(0.03)$ & 0.006 & 0.017 & 0.001 & 0.000 & -0.004 & -0.014 \\
\hline$P(0.1)$ & 1.94 & 2.50 & 4.07 & 4.12 & 2.92 & 3.05 \\
\hline $\mathrm{Ru}(0.05)$ & -0.000 & 0.004 & 0.002 & -0.000 & -0.002 & 0.000 \\
\hline $\mathrm{Sb}(0.05)$ & -0.007 & -0.007 & 0.000 & 0.001 & -0.008 & -0.002 \\
\hline Si $(0.02)$ & 51.9 & 55.1 & 58.1 & 52.5 & 52.6 & 53.2 \\
\hline Sr $(0.003)$ & 0.001 & 0.001 & 0.001 & 0.000 & 0.001 & 0.001 \\
\hline Th $(0.15)$ & 0.261 & 0.198 & 0.075 & 0.062 & 0.092 & 0.104 \\
\hline$T i(0.005)$ & 0.043 & 0.042 & 0.026 & 0.018 & 0.021 & 0.029 \\
\hline $\mathrm{U}(0.015)$ & 0.447 & 0.447 & 0.282 & 0.315 & 0.316 & 0.389 \\
\hline$V(0.01)$ & 0.003 & 0.003 & 0.001 & 0.001 & 0.000 & -0.001 \\
\hline$Y(0.01)$ & 0.001 & 0.001 & 0.000 & 0.000 & 0.000 & 0.000 \\
\hline $\operatorname{Zn}(0.02)$ & -0.057 & -0.064 & -0.038 & -0.069 & -0.037 & -0.057 \\
\hline $\operatorname{Zr}(0.01)$ & 0.013 & 0.002 & -0.007 & -0.005 & 0.001 & 0.001 \\
\hline
\end{tabular}

(a) Numbers in parentheses are instrument detection limits.

(b) Negative numbers are the result of random variation at low concentrations. 
Table A.3. (contd)

\begin{tabular}{|c|c|c|c|c|c|c|}
\hline & WVDG-7 & WVDG-8 & WVDG-11R & WVDG-12R & WVDG-13R & WVDG-14R \\
\hline Days of Test & 7 & 7 & 7 & 7 & 7 & 7 \\
\hline Date Test Began & 26-NOV-90 & 27-NOV-90 & 26-NOV-90 & 26-NOV-90 & 26-NOV-90 & 27-NOV-90 \\
\hline Date Test Ended & 03-DEC-90 & 04-DEC-90 & 03-DEC-90 & 03-DEC-90 & 03-DEC-90 & 04-DEC-90 \\
\hline Specimen Wgt., g & 3.8715 & 3.9792 & 3.8572 & 3.9742 & 3.7614 & 3.8252 \\
\hline Leachant Volume, $\mathrm{mL}$ & 38.71 & 39.78 & 38.58 & 39.75 & 37.60 & 38.27 \\
\hline SA/V & 2000.3 & 2000.6 & 1999.6 & 1999.6 & 2000.7 & 1999.1 \\
\hline Specimen Mesh Size & $-100+200$ & $-100+200$ & $-100+200$ & $-100+200$ & $-100+200$ & $-100+200$ \\
\hline Initial pH & 6.44 & 6.44 & 6.44 & 6.44 & 6.44 & 6.44 \\
\hline Final pH & 9.42 & 9.84 & 10.00 & 9.86 & 10.00 & 10.04 \\
\hline Total Init. Wgt., g & 121.74 & 123.10 & 123.51 & 123.75 & 119.92 & 123.33 \\
\hline Total Final Weight, $\mathrm{g}$ & 121.36 & 121.94 & 122.85 & 122.16 & 117.92 & 117.99 \\
\hline Run Order and Blind No. & $23-3$ & $37-3$ & $15-3$ & $6-3$ & $13-3$ & $30-3$ \\
\hline Date of Analysis & 20-DEC-90 & 20-DEC-90 & 20-DEC-90 & 20-DEC-90 & 20-DEC-90 & 20-DEC-90 \\
\hline Analytical Number & $90-8054$ & $90-8068$ & $90-8046$ & $90-8037$ & $90-8044$ & $90-8061$ \\
\hline Elements & \multicolumn{6}{|c|}{ Leachate Analyzed Concentration, $\mathrm{mg} / \mathrm{L}$} \\
\hline $\mathrm{Al}(0.05)^{(\mathfrak{a})}$ & 9.26 & 10.9 & 13.0 & 12.3 & 13.2 & $15.0^{(\mathrm{b})}$ \\
\hline B $(0.01)$ & 12.5 & 8.74 & 14.2 & 14.2 & 16.0 & 20.8 \\
\hline $\mathrm{Ba}(0.005)$ & 0.002 & 0.001 & 0.003 & 0.002 & 0.001 & 0.002 \\
\hline $\mathrm{Ca}(0.02)$ & 0.011 & 0.003 & $-0.018^{(c)}$ & -0.033 & -0.049 & 0.002 \\
\hline $\mathrm{Cd}(0.005)$ & 0.001 & -0.002 & 0.000 & -0.001 & 0.002 & 0.001 \\
\hline $\mathrm{Ce}(0.05)$ & 0.006 & 0.003 & 0.019 & 0.005 & 0.016 & 0.008 \\
\hline $\mathrm{Cr}(0.02)$ & 0.003 & 0.001 & 0.001 & -0.003 & -0.004 & 0.003 \\
\hline $\mathrm{Cu}(0.005)$ & 0.003 & 0.010 & -0.001 & 0.012 & 0.000 & 0.008 \\
\hline $\mathrm{Fe}(0.01)$ & 0.535 & 0.61 & 0.668 & 0.540 & 0.689 & 1.41 \\
\hline $\mathrm{K}(0.3)$ & 1.87 & 1.61 & 5.40 & 5.21 & 5.36 & 6.51 \\
\hline La $(0.01)$ & 0.004 & -0.001 & 0.004 & 0.001 & 0.002 & 0.005 \\
\hline Li $(0.005)$ & 3.89 & 5.00 & 6.0 & 6.12 & 6.74 & 8.55 \\
\hline $\mathrm{Mg}(0.06)$ & 0.053 & 0.127 & 0.137 & 0.094 & 0.138 & 0.256 \\
\hline $\operatorname{Mn}(0.005)$ & 0.035 & 0.067 & 0.067 & 0.058 & 0.067 & 0.133 \\
\hline Mo $(0.02)$ & 0.020 & 0.024 & 0.031 & 0.022 & 0.024 & 0.034 \\
\hline $\mathrm{Na}(0.02)$ & 20.3 & 25.9 & 28.7 & 29.6 & 33.8 & 45.1 \\
\hline $\mathrm{Nd}(0.03)$ & 0.006 & 0.010 & 0.000 & 0.004 & 0.006 & 0.020 \\
\hline $\mathrm{Ni}(0.03)$ & 0.006 & -0.002 & 0.029 & 0.000 & 0.012 & 0.013 \\
\hline$P(0.1)$ & 1.84 & 2.98 & 3.69 & 3.49 & 3.88 & 4.60 \\
\hline $\mathrm{Ru}(0.05)$ & 0.004 & -0.004 & 0.006 & -0.001 & 0.002 & 0.004 \\
\hline $\mathrm{Sb}(0.05)$ & -0.005 & -0.006 & 0.010 & 0.000 & -0.005 & -0.001 \\
\hline Si $(0.02)$ & 47.1 & 55.8 & 47.0 & 44.9 & 48.2 & 54.2 \\
\hline $\operatorname{Sr}(0.003)$ & 0.001 & 0.001 & 0.002 & 0.001 & 0.001 & 0.001 \\
\hline Th $(0.15)$ & 0.178 & 0.094 & 0.080 & 0.066 & 0.081 & 0.110 \\
\hline $\mathrm{Ti}(0.005)$ & 0.026 & 0.027 & 0.033 & 0.030 & 0.025 & 0.040 \\
\hline$U(0.015)$ & 0.300 & 0.447 & 0.333 & 0.389 & 0.471 & 0.526 \\
\hline $\mathrm{V}(0.01)$ & 0.001 & 0.001 & 0.003 & 0.002 & 0.003 & 0.004 \\
\hline$Y(0.01)$ & 0.001 & 0.000 & 0.001 & 0.000 & 0.001 & 0.001 \\
\hline $\mathrm{Zn}(0.02)$ & -0.051 & -0.062 & -0.083 & -0.081 & -0.092 & -0.087 \\
\hline$Z_{r}(0.01)$ & 0.007 & 0.001 & -0.003 & 0.001 & 0.000 & -0.002 \\
\hline
\end{tabular}

(a) Numbers in parentheses are instrument detection limits.

(b) Data excluded from calculations because leachant loss $>10 \%$

(c) Negative numbers are the result of random variation at low concentrations. 
Table A.3. (contd)

Days of Test

Date Test Began

Date Test Ended

Specimen Wgt., g

Leachant Volume, $\mathrm{mL}$

SA/V

Specimen Mesh Size

WVDG-15
7
$27-$ NOV-90
04-DEC-90

WVDG-16

WVDG-17

WVDG-18

WVDG-19

WVDG-20

77

26-NOV-90

7

77

7

04-DEC-90

.

Initial $\mathrm{pH}$

3.773

3.7982

26-NOV-90

27-NOV-90

26-NOV-90

27-NOV-90

3.773
27.74

2720.5

37.98

03-DEC-90

04-DEC-90

03-DEC-90

04-DEC-90

Final $\mathrm{pH}$

$-100+200$

2000.1

4.1398

3.6720

3.9782

39.78

3.6559

41.39

36.71

$2000.4 \quad 2000.5$

2000.1

36.56

$-100+200 \quad-100+200$

$-100+200$

$-100+200$

$-100+200$

$\begin{array}{llllll}6.44 & 6.44 & 6.44 & 6.44 & 6.44 & 6.44\end{array}$

9.91

9.52

10.28

10.07

9.87

9.56

Total Init. Wgt., g

117.67

117.06

125.59

118.20

123.18

119.44

115.85

115.29

124.94

117.57

120.70

113.99

Run Order and Blind No.

41-3

14-3

11-3

38-3

7-3

48-3

Date of Analysis

20-DEC-90

20-DEC-90

20-DEC-90

20-DEC-90

20-DEC-90

20-DEC-90

Analytical Number

90-8072 90-8069

90-8038

90-8078

Elements

\begin{tabular}{|c|c|c|c|c|}
\hline 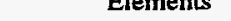 & \multicolumn{4}{|c|}{ - } \\
\hline $\mathrm{Al}(0.05)^{(\mathrm{a})}$ & 11.2 & 10.8 & 11.1 & 13. \\
\hline B $(0.01)$ & 23.1 & 15.4 & 17.5 & 15. \\
\hline $\mathrm{Ba}(0.005)$ & 0.004 & 0.005 & 0.006 & \\
\hline $\mathrm{Ca}(0.02)$ & 0.010 & $-0.030^{(c)}$ & -0.037 & -0 \\
\hline $\mathrm{Cd}(0.005)$ & 0.001 & -0.001 & 0.000 & \\
\hline $\mathrm{Ce}(0.05)$ & 0.002 & 0.022 & 0.026 & \\
\hline $\mathrm{Cr}(0.02)$ & 0.030 & -0.001 & 0.033 & \\
\hline $\mathrm{Cu}(0.005)$ & 0.006 & -0.000 & 0.008 & \\
\hline $\mathrm{Fe}(0.01)$ & 0.511 & 0.491 & 0.826 & \\
\hline K $(0.3)$ & 3.01 & 2.62 & 3.93 & 3.3 \\
\hline $\mathrm{La}(0.01)$ & -0.002 & 0.004 & 0.002 & -0 . \\
\hline Li $(0.005)$ & 7.6 & 4.39 & 6.2 & \\
\hline $\mathrm{Mg}(0.06)$ & 0.167 & 0.081 & 0.222 & \\
\hline $\operatorname{Mn}(0.005)$ & 0.135 & 0.070 & 0.199 & \\
\hline Mo $(0.02)$ & 0.237 & 0.045 & 0.271 & \\
\hline $\mathrm{Na}(0.02)$ & 39.7 & 21.7 & 42.2 & 36. \\
\hline Nd $(0.03)$ & 0.035 & 0.004 & 0.076 & \\
\hline $\mathrm{Ni}(0.03)$ & -0.009 & 0.009 & 0.010 & -0 \\
\hline$P(0.1)$ & 2.80 & 2.63 & 2.81 & \\
\hline$R u(0.05)$ & -0.001 & 0.004 & -0.003 & \\
\hline Sb $(0.05)$ & -0.015 & 0.007 & -0.002 & \\
\hline $\mathrm{Si}(0.02)$ & 48.9 & 11.8 & 47.5 & 56 \\
\hline St $(0.003)$ & 0.001 & 0.001 & 0.001 & \\
\hline $\operatorname{Th}(0.15)$ & 0.018 & 0.050 & 0.055 & \\
\hline $\mathrm{Ti}(0.005)$ & 0.018 & 0.008 & 0.027 & \\
\hline U $(0.015)$ & 0.622 & 0.062 & 0.032 & \\
\hline$V(0.01)$ & 0.001 & 0.004 & 0.004 & 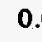 \\
\hline$Y(0.01)$ & -0.000 & 0.001 & 0.001 & -0 \\
\hline $\mathrm{Zn}(0.02)$ & -0.059 & -0.073 & -0.064 & -0 \\
\hline $\mathrm{Zr}(0.01)$ & -0.005 & -0.003 & -0.002 & \\
\hline $\begin{array}{l}\text { (a) Numbers in pa } \\
\text { (b) Data excluded } \\
\text { (c) Negative numb }\end{array}$ & $\begin{array}{l}\text { Ilations } \\
\text { result }\end{array}$ & $\begin{array}{l}\text { detection lir } \\
\text { leachant } 1 \\
\text { mariatio }\end{array}$ & $\begin{array}{l}10 \% \\
\text { ow conc }\end{array}$ & \\
\hline
\end{tabular}


Table A.3. (contd)

Days of Test

Date Test Began

Date Test Ended

WVDG-21
7
27-NOV-90
04-DEC-90

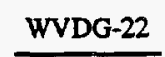
7

40-3 20-DEC-90 90-8071 27-NOV-90 04-DEC-90

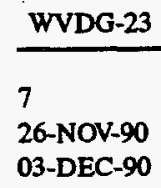

\section{5-3}

20-DEC-90

20-DEC-90

28-3

20-DEC-90

90-8059 20-DEC-90

90-8048

Leachate Analyzed Concentration, $\mathrm{mg} / \mathrm{L}$

\begin{tabular}{|c|c|c|c|c|c|c|}
\hline $\mathrm{Al}(0.05)^{(\mathrm{a})}$ & 20.5 & 19.3 & 13.4 & 15.4 & 12.8 & 12.8 \\
\hline B $(0.01)$ & 13.7 & 14.8 & 19.2 & 16.8 & 13.1 & 14.8 \\
\hline $\mathrm{Ba}(0.005)$ & 0.009 & 0.007 & 0.017 & 0.004 & 0.006 & 0.003 \\
\hline $\mathrm{Ca}(0.02)$ & 0.018 & 0.014 & 0.046 & $-0.003^{(b)}$ & 0.001 & 0.034 \\
\hline $\mathrm{Cd}(0.005)$ & -0.001 & 0.001 & 0.001 & -0.001 & 0.001 & 0.001 \\
\hline $\mathrm{Ce}(0.05)$ & 0.058 & 0.155 & 0.103 & 0.009 & 0.029 & 0.000 \\
\hline Cr $(0.02)$ & 0.006 & 0.003 & 0.020 & 0.006 & 0.003 & -0.002 \\
\hline $\mathrm{Cu}(0.005)$ & 0.009 & 0.020 & 0.016 & 0.005 & 0.010 & 0.012 \\
\hline $\mathrm{Fe}(0.01)$ & 1.91 & 0.894 & 4.33 & 0.639 & 1.21 & 0.332 \\
\hline K $(0.3)$ & 3.84 & 2.67 & 2.17 & 2.28 & 3.17 & 2.49 \\
\hline $\operatorname{La}(0.01)$ & 0.002 & 0.009 & 0.010 & 0.003 & 0.003 & 0.000 \\
\hline Li $(0.005)$ & 5.22 & 4.99 & 5.00 & 5.27 & 4.83 & 4.62 \\
\hline $\mathrm{Mg}(0.06)$ & 0.035 & 0.019 & 0.063 & 0.018 & 0.013 & 0.029 \\
\hline $\operatorname{Mn}(0.005)$ & 0.248 & 0.181 & 0.096 & 0.115 & 0.175 & 0.016 \\
\hline Mo $(0.02)$ & 0.044 & 0.170 & 0.038 & 0.047 & 0.040 & 0.039 \\
\hline $\mathrm{Na}(0.02)$ & 33.6 & 21.8 & 22.4 & 24.1 & 22.6 & 20.3 \\
\hline $\mathrm{Nd}(0.03)$ & 0.004 & 0.007 & 0.016 & 0.014 & 0.016 & 0.007 \\
\hline $\mathrm{Ni}(0.03)$ & 0.012 & 0.028 & 0.026 & 0.001 & 0.005 & -0.008 \\
\hline$P(0.1)$ & 4.07 & 1.23 & 2.56 & 1.78 & 2.50 & 1.31 \\
\hline $\mathrm{Ru}(0.05)$ & -0.000 & 0.001 & 0.000 & -0.001 & 0.005 & -0.003 \\
\hline $\mathrm{Sb}(0.05)$ & -0.029 & -0.002 & -0.003 & 0.002 & 0.002 & -0.009 \\
\hline $\mathrm{Si}(0.02)$ & 52.4 & 50.8 & 52.2 & 47.8 & 56.3 & 38.8 \\
\hline Sr $(0.003)$ & 0.001 & 0.003 & 0.002 & 0.001 & 0.001 & 0.001 \\
\hline Th $(0.15)$ & 0.417 & 0.372 & 2.052 & 0.102 & 0.424 & 0.048 \\
\hline $\mathrm{Ti}(0.005)$ & 0.048 & 0.092 & 0.116 & 0.013 & 0.034 & 0.007 \\
\hline $\mathrm{U}(0.015)$ & 1.112 & 0.073 & 1.140 & 0.866 & 0.062 & 0.065 \\
\hline$V(0.01)$ & 0.003 & 0.004 & 0.014 & 0.002 & 0.004 & 0.001 \\
\hline$Y(0.01)$ & 0.002 & 0.005 & 0.004 & 0.000 & 0.001 & 0.000 \\
\hline $\mathrm{Zn}(0.02)$ & -0.010 & -0.102 & -0.074 & -0.090 & -0.070 & -0.069 \\
\hline $\mathrm{Zr}(0.01)$ & -0.002 & 0.003 & 0.005 & 0.003 & -0.001 & -0.002 \\
\hline
\end{tabular}

(a) Numbers in parentheses are instrument detection limits.

(b) Negative numbers are the result of random variation at low concentrations. 
Table A.3. (contd)

Days of Test

Date Test Began

Date Test Ended

Specimen Wgt.,

Leachant Volume, $\mathrm{mL}$

SA/V

Specimen Mesh Size

Initial $\mathrm{pH}$

Final pH

Total Init. Wgt.,

Total Final Weight, $g$

Run Order and Blind No.

Date of Analysis

Analytical Number

Elements

\begin{tabular}{l}
\hline Al $(0.05)^{(a)}$ \\
B $(0.01)$ \\
Ba $(0.005)$ \\
Ca $(0.02)$ \\
Cd $(0.005)$ \\
Ce $(0.05)$ \\
Cr $(0.02)$ \\
Cu $(0.005)$ \\
Fe $(0.01)$ \\
K $(0.3)$ \\
La $(0.01)$ \\
Li $(0.005)$ \\
Mg $(0.06)$ \\
Mn $(0.005)$ \\
Mo $(0.02)$ \\
Na $(0.02)$ \\
Nd $(0.03)$ \\
Ni $(0.03)$ \\
P $(0.1)$ \\
Ru $(0.05)$ \\
Sb $(0.05)$ \\
Si $(0.02)$ \\
Sr $(0.003)$ \\
Th $(0.15)$ \\
Ti $(0.005)$ \\
U $(0.015)$ \\
V $(0.01)$ \\
Y $(0.01)$ \\
Zn $(0.02)$ \\
Zr $(0.01)$ \\
\hline
\end{tabular}

\begin{tabular}{|c|c|c|c|c|c|}
\hline WVDG-27 & WVDG-28 & WVDG-29 & WVDG-30 & WVDG-31B & WVDG-31C \\
\hline 7 & 7 & 7 & 7 & 7 & 7 \\
\hline 26-NOV-90 & 26-NOV-90 & 26-NOV-90 & 27-NOV-90 & 26-NOV-90 & 26-NOV-90 \\
\hline 03-DEC-90 & 03-DEC-90 & 03-DEC-90 & 04-DEC-90 & 03-DEC-90 & 03-DEC-90 \\
\hline 3.7983 & 3.8052 & 4.2921 & 4.0645 & 3.7532 & 3.7561 \\
\hline 37.97 & 38.06 & 42.93 & 40.64 & 37.53 & 37.54 \\
\hline 2000.7 & 1999.6 & 1999.6 & 2000.2 & 1999.6 & 2001.1 \\
\hline$-100+200$ & $-100+200$ & $-100+200$ & $-100+200$ & $-100+200$ & $-100+200$ \\
\hline 6.44 & 6.44 & 6.44 & 6.44 & 6.44 & 6.44 \\
\hline 9.62 & 9.57 & 9.92 & 9.71 & 9.93 & 10.01 \\
\hline 121.13 & 120.25 & 126.45 & 122.40 & 120.19 & 119.41 \\
\hline 120.07 & 114.00 & 125.55 & 121.16 & 118.00 & 118.61 \\
\hline $3-3$ & $19-3$ & $4-3$ & $33-3$ & $10-3$ & $2-3$ \\
\hline $20-\mathrm{DEC}-90$ & 20-DEC-90 & 20-DEC-90 & 20-DEC-90 & 20-DEC-90 & 20-DEC-90 \\
\hline $90-8034$ & $90-8050$ & $90-8035$ & $90-8064$ & $90-8041$ & $90-8033$ \\
\hline
\end{tabular}

Leachate Analyzed Concentration, $\mathrm{mg} / \mathrm{L}$

\begin{tabular}{|c|c|c|c|c|c|}
\hline 19.0 & $13.6^{(\mathrm{b})}$ & 10.2 & 14.2 & 13.4 & 12.9 \\
\hline 22.0 & 13.7 & 16.1 & 16.2 & 14.5 & 14.0 \\
\hline 0.003 & 0.006 & 0.009 & 0.015 & 0.002 & 0.000 \\
\hline$-0.041^{(c)}$ & 0.006 & -0.014 & 0.032 & -0.042 & -0.043 \\
\hline 0.001 & 0.000 & -0.002 & 0.000 & 0.001 & -0.002 \\
\hline 0.099 & 0.118 & 0.006 & 0.072 & -0.002 & -0.004 \\
\hline 0.020 & 0.012 & 0.001 & 0.010 & 0.008 & -0.000 \\
\hline 0.007 & 0.017 & -0.002 & 0.010 & 0.000 & -0.003 \\
\hline 1.04 & 1.32 & 1.006 & 1.84 & 1.14 & 0.527 \\
\hline 2.07 & 1.80 & 3.42 & 2.900 & 4.59 & 4.86 \\
\hline 0.005 & 0.003 & -0.003 & 0.006 & -0.001 & -0.001 \\
\hline 6.22 & 5.70 & 6.09 & 5.8 & 6.23 & 5.93 \\
\hline-0.004 & 0.008 & 0.332 & 0.073 & 0.224 & 0.083 \\
\hline 0.024 & 0.043 & 0.057 & 0.130 & 0.125 & 0.051 \\
\hline 0.168 & 0.177 & 0.053 & 0.108 & 0.037 & 0.023 \\
\hline 32.8 & 22.7 & 34.6 & 29.4 & 29.4 & 28.2 \\
\hline 0.005 & 0.015 & 0.009 & 0.054 & 0.014 & 0.005 \\
\hline 0.010 & 0.009 & -0.011 & 0.015 & -0.008 & -0.004 \\
\hline 3.11 & $1: 50$ & 5.96 & 2.70 & 3.91 & 3.51 \\
\hline-0.008 & -0.010 & -0.010 & 0.001 & -0.008 & -0.007 \\
\hline-0.010 & 0.012 & 0.000 & -0.005 & 0.013 & 0.016 \\
\hline 47.9 & 57.6 & 51.6 & 49.9 & 49.3 & 46.8 \\
\hline 0.001 & 0.002 & 0.000 & 0.002 & 0.001 & 0.000 \\
\hline 0.480 & 0.254 & 0.113 & 0.306 & 0.110 & 0.075 \\
\hline 0.132 & 0.122 & 0.016 & 0.075 & 0.050 & 0.019 \\
\hline 0.037 & 1.22 & 0.063 & 0.4 & 0.415 & 0.333 \\
\hline 0.004 & -0.000 & 0.001 & 0.004 & 0.007 & 0.001 \\
\hline 0.003 & 0.003 & -0.000 & 0.002 & 0.001 & 0.000 \\
\hline-0.114 & -0.071 & -0.067 & -0.076 & -0.085 & -0.082 \\
\hline 0.004 & 0.000 & -0.006 & -0.001 & -0.004 & 0.002 \\
\hline
\end{tabular}

(a) Numbers in parentheses are instrument detection limits.

(b) Data excluded from calculations because leachant loss $>10 \%$.

(c) Negative numbers are the result of random variation at low concentrations. 
Table A.3. (contd)

\begin{tabular}{|c|c|c|c|c|c|c|}
\hline & WVDG-33 & WVDG-34 & WVDG-35 & WVDG-36 & WVDG-37 & WVDG-38 \\
\hline Days of Test & 7 & 7 & 7 & $\mathbf{7}$ & 7 & 7 \\
\hline Date Test Began & 26-NOV-90 & 27-NOV-90 & 27-NOV-90 & 27-NOV-90 & 26-NOV-90 & 26-NOV-90 \\
\hline Date Test Ended & 03-DEC-90 & 04-DEC-90 & 04-DEC-90 & 04-DEC-90 & 03-DEC-90 & 03-DEC-90 \\
\hline Specimen Wgt., g & 3.8227 & 3.7762 & 3.7581 & 3.7515 & 4.0532 & 3.768 \\
\hline Leachant Volume, $\mathrm{mL}$ & 38.23 & 37.78 & 37.56 & 37.51 & 40.53 & 37.37 \\
\hline SA/V & 1999.8 & 1999.0 & 2001.1 & 2000.3 & 2000.1 & 1999.9 \\
\hline Specimen Mesh Size & $-100+200$ & $-100+200$ & $-100+200$ & $-100+200$ & $-100+200$ & $-100+200$ \\
\hline Initisl pH & 6.44 & 6.44 & 6.44 & 6.44 & 6.44 & 6.44 \\
\hline Final pH & 10.22 & 10.42 & 11.06 & 9.63 & 10.83 & 10.37 \\
\hline Total Init. Wgt., g & 121.26 & 120.94 & 120.76 & 121.44 & 122.84 & 120.26 \\
\hline Total Final Weight, $g$ & 118.36 & 121.07 & 119.65 & 120.12 & 122.23 & 119.56 \\
\hline Run Order and Blind No. & $16-3$ & $47-3$ & 34-3 & $27-3$ & $1-3$ & $12-3$ \\
\hline Date of Analysis & 20-DEC-90 & 20-DEC-90 & 20-DEC-90 & 20-DEC-90 & 20-DEC-90 & 20-DEC-90 \\
\hline Analytical Number & $90-8047$ & $90-8077$ & $90-8065$ & $90-8058$ & $90-8032$ & $90-8043$ \\
\hline Elements & \multicolumn{6}{|c|}{ Leachate Analyzed Concentration, $\mathrm{mg} / \mathrm{L}$} \\
\hline $\mathrm{Al}(0.05)^{(\mathrm{a})}$ & 10.1 & 6.67 & 19.6 & 6.79 & 15.6 & 14.5 \\
\hline B $(0.01)$ & 14.0 & 24.9 & 17.8 & 16.4 & 10.7 & 9.25 \\
\hline $\mathrm{Ba}(0.005)$ & 0.005 & 0.000 & 0.004 & 0.001 & 0.001 & 0.002 \\
\hline $\mathrm{Ca}(0.02)$ & 0.030 & $-0.006^{(b)}$ & -0.003 & -0.004 & -0.023 & -0.049 \\
\hline $\mathrm{Cd}(0.005)$ & -0.001 & -0.001 & -0.000 & 0.001 & 0.002 & -0.001 \\
\hline $\mathrm{Ce}(0.05)$ & -0.010 & -0.015 & -0.001 & 0.019 & 0.026 & 0.066 \\
\hline $\operatorname{Cr}(0.02)$ & 0.009 & 0.068 & 0.005 & 0.005 & 0.030 & 0.039 \\
\hline $\mathrm{Cu}(0.005)$ & 0.020 & 0.016 & 0.004 & 0.017 & 0.026 & 0.023 \\
\hline $\mathrm{Fe}(0.01)$ & 1.38 & 0.418 & 2.48 & 0.592 & 1.27 & 1.36 \\
\hline $\mathrm{K}(0.3)$ & 7.39 & 9.54 & 14.0 & 5.40 & 8.05 & 6.32 \\
\hline La $(0.01)$ & -0.002 & -0.004 & 0.001 & 0.005 & 0.006 & 0.015 \\
\hline $\operatorname{Li}(0.005)$ & 7.293 & 9.70 & 11.5 & 5.00 & 7.68 & 6.18 \\
\hline $\mathrm{Mg}(0.06)$ & 0.210 & 0.012 & 0.356 & 0.005 & 0.015 & 0.016 \\
\hline $\operatorname{Mn}(0.005)$ & 0.135 & 0.068 & 0.207 & 0.004 & 0.010 & 0.086 \\
\hline Mo $(0.02)$ & 0.146 & 0.537 & 0.096 & 0.382 & 0.412 & 0.373 \\
\hline $\mathrm{Na}(0.02)$ & 38.8 & 52.9 & 67.4 & 22.6 & 44.4 & 29.1 \\
\hline Nd $(0.03)$ & 0.026 & 0.039 & 0.003 & 0.003 & 0.086 & 0.039 \\
\hline $\mathrm{Ni}(0.03)$ & -0.011 & -0.010 & -0.006 & 0.015 & 0.015 & 0.049 \\
\hline$P(0.1)$ & 4.44 & 3.85 & 1.49 & 0.639 & 0.777 & 0.739 \\
\hline $\mathrm{Ru}(0.05)$ & -0.008 & -0.004 & -0.001 & 0.002 & -0.005 & -0.000 \\
\hline Sb $(0.05)$ & -0.020 & 0.001 & -0.007 & 0.011 & 0.006 & -0.014 \\
\hline Si $(0.02)$ & 55.1 & 60.0 & 65.9 & 52.7 & 56.1 & 50.9 \\
\hline Sr $(0.003)$ & 0.002 & 0.001 & 0.001 & 0.002 & 0.003 & 0.005 \\
\hline Th $(0.15)$ & 0.163 & 0.044 & 0.059 & 0.271 & 0.235 & 0.411 \\
\hline $\mathrm{Ti}(0.005)$ & 0.044 & 0.040 & 0.012 & 0.076 & 0.196 & 0.234 \\
\hline U $(0.015)$ & 0.474 & 0.447 & 4.25 & 0.046 & 0.049 & 0.040 \\
\hline$V(0.01)$ & 0.000 & 0.001 & 0.003 & 0.004 & 0.002 & 0.005 \\
\hline$Y(0.01)$ & 0.000 & -0.000 & 0.000 & 0.002 & 0.003 & 0.007 \\
\hline $\operatorname{Zn}(0.02)$ & -0.047 & -0.030 & -0.128 & -0.035 & -0.080 & -0.081 \\
\hline $\operatorname{Zr}(0.01)$ & -0.005 & -0.003 & -0.003 & 0.024 & 0.033 & 0.056 \\
\hline
\end{tabular}

(a) Numbers in parentheses are instrument detection limits.

(b) Negative numbers are the result of random variation at low concentrations. 
Table A.3. (contd)

Days of Test

Date Test Began

Date Test Ended

Specimen Wgt.,

Leachant Volume, $\mathrm{mL}$

SA/V

Specimen Mesh Size

Initial $\mathbf{p H}$

Final pH

Total Init. Wgt., $g$

Total Final Weight, $\mathrm{g}$

Run Order and Blind No.

Date of Analysis

Analytical Number

Elements

Al $(0.05)^{(a)}$
B $(0.01)$
Ba $(0.005)$
Ca $(0.02)$
Cd $(0.005)$
Ce $(0.05)$
Cr $(0.02)$
Cu $(0.005)$
Fe $(0.01)$
K $(0.3)$
La $(0.01)$
Li $(0.005)$
Mg $(0.06)$
Mn $(0.005)$
Mo $(0.02)$
Na $(0.02)$
Nd $(0.03)$
Ni $(0.03)$
P $(0.1)$
Ru(0.05)
Sb $(0.05)$
Si $(0.02)$
Sr $(0.003)$
Th $(0.15)$
Ti $(0.005)$
U $(0.015)$
V (0.01)
Y (0.01)
Zn $(0.02)$
Zr $(0.01)$

(a) Numbers in parentheses are instrument detection limits.

(b) Negative numbers are the result of random variation at low concentrations.

Leachate Analyzed Concentration, mg/L

\begin{tabular}{|c|c|c|c|c|c|}
\hline 14.0 & 6.36 & 7.95 & 5.000 & 13.8 & 13.1 \\
\hline 20.6 & 14.3 & 14.3 & 16.1 & 15.4 & 25.5 \\
\hline 0.005 & 0.002 & 0.002 & 0.002 & 0.005 & 0.001 \\
\hline 0.021 & 0.001 & $-0.002^{(b)}$ & 0.008 & -0.039 & -0.059 \\
\hline 0.000 & 0.000 & 0.003 & 0.000 & 0.001 & -0.000 \\
\hline 0.003 & -0.007 & -0.015 & -0.002 & 0.032 & 0.005 \\
\hline 0.008 & 0.001 & -0.002 & 0.014 & 0.010 & 0.003 \\
\hline 0.015 & 0.015 & 0.009 & 0.013 & 0.018 & 0.009 \\
\hline 1.81 & 1.01 & 1.59 & 0.814 & 3.89 & 2.18 \\
\hline-0.609 & 8.99 & 9.556 & 12.0 & 3.18 & 8.84 \\
\hline 0.002 & -0.003 & -0.004 & 0.001 & 0.004 & 0.002 \\
\hline 7.7 & 7.61 & 9.01 & 9.74 & 5.13 & 9.77 \\
\hline 0.557 & 0.226 & 0.013 & 0.226 & 0.049 & 0.019 \\
\hline 0.019 & 0.005 & 0.013 & 0.123 & 0.415 & 0.012 \\
\hline 0.083 & 0.082 & 0.079 & 0.759 & 0.035 & 0.064 \\
\hline 43.9 & 41.7 & 63.4 & 57.6 & 16.1 & 52.2 \\
\hline 0.033 & 0.007 & 0.014 & 0.037 & 0.024 & 0.010 \\
\hline-0.001 & -0.008 & -0.014 & -0.007 & 0.014 & 0.001 \\
\hline 7.38 & 1.18 & 10.3 & 11.3 & 1.83 & 0.923 \\
\hline-0.001 & -0.002 & -0.012 & 0.001 & -0.004 & -0.006 \\
\hline-0.008 & -0.013 & -0.017 & 0.009 & 0.012 & 0.001 \\
\hline 48.8 & 65.9 & 68.7 & 65.5 & 51.9 & 54.6 \\
\hline 0.001 & 0.001 & 0.001 & 0.001 & 0.002 & 0.001 \\
\hline 0.315 & 0.043 & 0.336 & 0.038 & 1.29 & 0.319 \\
\hline 0.031 & 0.005 & 0.022 & 0.031 & 0.099 & 0.029 \\
\hline 0.100 & 2.12 & 2.83 & 0.022 & 2.27 & 2.14 \\
\hline 0.003 & 0.002 & 0.001 & 0.003 & 0.008 & 0.002 \\
\hline 0.001 & -0.001 & -0.001 & 0.000 & 0.003 & 0.000 \\
\hline-0.072 & -0.038 & 0.050 & -0.012 & -0.092 & -0.093 \\
\hline-0.004 & -0.003 & -0.005 & -0.003 & 0.007 & 0.002 \\
\hline
\end{tabular}


Table A.3. (contd)

\begin{tabular}{|c|c|c|c|c|c|c|}
\hline & WVDG-45 & WVDG-46 & WVDG-47 & WVDG-48 & $\begin{array}{c}\text { WVDG-49 } \\
\text { (ARM-1) }\end{array}$ & $\begin{array}{l}\text { WVDG-50 } \\
\text { (ARM-1) } \\
\end{array}$ \\
\hline Days of Test & 7 & 7 & 7 & 7 & 7 & 7 \\
\hline Date Test Began & 27-NOV-90 & 26-NOV-90 & 27-NOV-90 & 26-NOV-90 & 26-NOV-90 & 27-NOV-90 \\
\hline Date Test Ended & 04-DEC-90 & 03-DEC-90 & 04-DEC-90 & 03-DEC-90 & 03-DEC-90 & 04-DEC-90 \\
\hline Specimen Wgt., $\mathbf{g}$ & 3.7480 & 3.9912 & 3.7644 & 3.9323 & 3.7844 & 3.7237 \\
\hline Leachant Volume, $\mathrm{mL}$ & 37.50 & 39.91 & 37.63 & 39.33 & 37.42 & 37.24 \\
\hline SA/V & 1998.9 & 2000.1 & 2000.7 & 1999.6 & 2022.7 & 1999.8 \\
\hline Specimen Mesh Size & $-100+200$ & $-100+200$ & $-100+200$ & $-100+200$ & $-100+200$ & $-100+200$ \\
\hline Initial pH & 6.44 & 6.44 & 6.44 & 6.44 & 6.44 & 6.44 \\
\hline Final pH & 10.68 & 10.10 & 9.36 & 9.40 & 10.58 & 10.30 \\
\hline Total Init. Wgt., g & 120.55 & 123.24 & 119.46 & 123.63 & 121.01 & 120.48 \\
\hline Total Final Weight, $g$ & 120.06 & 122.65 & 114.12 & 121.55 & 120.87 & 117.46 \\
\hline Run Order and Blind No. & $46-3$ & $20-3$ & 44-3 & $18-3$ & 21-3 & $45-3$ \\
\hline Date of Analysis & 20-DEC-90 & 20-DEC-90 & 20-DEC-90 & 20-DEC-90 & 20-DEC-90 & 20-DEC-90 \\
\hline Analytical Number & $90-8076 b$ & $90-8051$ & $90-8075$ & $90-8049$ & $90-8052$ & $90-8076 a$ \\
\hline Elements & \multicolumn{6}{|c|}{ Leachate Analyzed Concentration, $\mathrm{mg} / \mathrm{L}$} \\
\hline Al $(0.05)^{(\mathbf{a})}$ & 17.1 & 7.88 & .7 .283 & 12.3 & 4.36 & 4.26 \\
\hline B $(0.01)$ & 11.6 & 26.2 & 16.1 & 11.6 & 17.6 & 17.2 \\
\hline $\mathrm{Ba}(0.005)$ & 0.003 & 0.002 & 0.005 & 0.002 & 0.005 & 0.005 \\
\hline $\mathrm{Ca}(0.02)$ & $-0.007^{(b)}$ & 0.007 & 0.015 & 0.012 & 0.169 & 0.211 \\
\hline$C d(0.005)$ & -0.002 & 0.000 & -0.001 & -0.001 & 0.001 & 0.001 \\
\hline $\mathrm{Ce}(0.05)$ & 0.006 & -0.008 & 0.018 & 0.007 & 0.008 & -0.001 \\
\hline $\mathrm{Cr}(0.02)$ & 0.007 & 0.007 & 0.014 & 0.006 & -0.004 & -0.004 \\
\hline $\mathrm{Cu}(0.005)$ & 0.018 & 0.008 & 0.011 & 0.019 & 0.007 & 0.002 \\
\hline $\mathrm{Fe}(0.01)$ & 1.72 & 1.27 & 5.52 & 0.377 & 0.012 & 0.019 \\
\hline $\mathrm{K}(0.3)$ & 10.6 & 8.12 & 3.56 & 4.00 & 0.083 & -0.711 \\
\hline La $(0.01)$ & 0.002 & -0.003 & 0.001 & 0.003 & 0.001 & -0.003 \\
\hline Li $(0.005)$ & 7.95 & 7.85 & 5.07 & 4.30 & 13.7 & 13.9 \\
\hline $\mathrm{Mg}(0.06)$ & 0.026 & 0.403 & 0.045 & 0.085 & 0.015 & 0.004 \\
\hline $\mathrm{Mn}(0.005)$ & 0.173 & 0.220 & 0.508 & 0.006 & 0.002 & 0.003 \\
\hline Mo $(0.02)$ & 0.096 & 0.057 & 0.049 & 0.249 & 5.85 & 5.50 \\
\hline $\mathrm{Na}(0.02)$ & 51.4 & 42.6 & 20.7 & 15.5 & 36.8 & 36.8 \\
\hline Nd $(0.03)$ & 0.012 & 0.002 & 0.026 & 0.005 & 0.000 & 0.001 \\
\hline $\mathrm{Ni}(0.03)$ & 0.001 & -0.012 & 0.008 & 0.006 & 0.034 & 0.030 \\
\hline$P(0.1)$ & 9.07 & 0.904 & 5.08 & 2.39 & 0.896 & 0.802 \\
\hline$R u(0.05)$ & -0.000 & -0.006 & -0.004 & -0.001 & 0.003 & 0.001 \\
\hline Sh $(0.05)$ & -0.015 & 0.004 & -0.004 & -0.008 & 0.004 & -0.005 \\
\hline Si $(0.02)$ & 54.9 & 58.6 & 59.8 & 43.0 & 61.5 & 60.1 \\
\hline Sr $(0.003)$ & 0.002 & 0.000 & 0.001 & 0.002 & 0.019 & 0.021 \\
\hline Th $(0.15)$ & 0.196 & 0.143 & 0.833 & 0.096 & 0.008 & 0.015 \\
\hline Ti $(0.005)$ & 0.039 & 0.015 & 0.098 & 0.070 & 0.015 & 0.017 \\
\hline U $(0.015)$ & 0.078 & 0.091 & 0.107 & 0.162 & 0.000 & 0.000 \\
\hline$V(0.01)$ & 0.003 & 0.001 & 0.005 & 0.001 & 0.008 & 0.006 \\
\hline$Y(0.01)$ & 0.000 & -0.000 & 0.002 & 0.001 & 0.000 & -0.000 \\
\hline $\mathrm{Zn}(0.02)$ & -0.094 & -0.040 & -0.031 & -0.065 & 0.034 & 0.018 \\
\hline $\mathrm{Zr}(0.01)$ & -0.004 & -0.005 & -0.005 & 0.001 & 0.010 & 0.009 \\
\hline
\end{tabular}

(a) Numbers in parentheses are instrument detection limits.

(b) Negative numbers are the result of random variation at low concentrations. 
Table A.3. (contd)

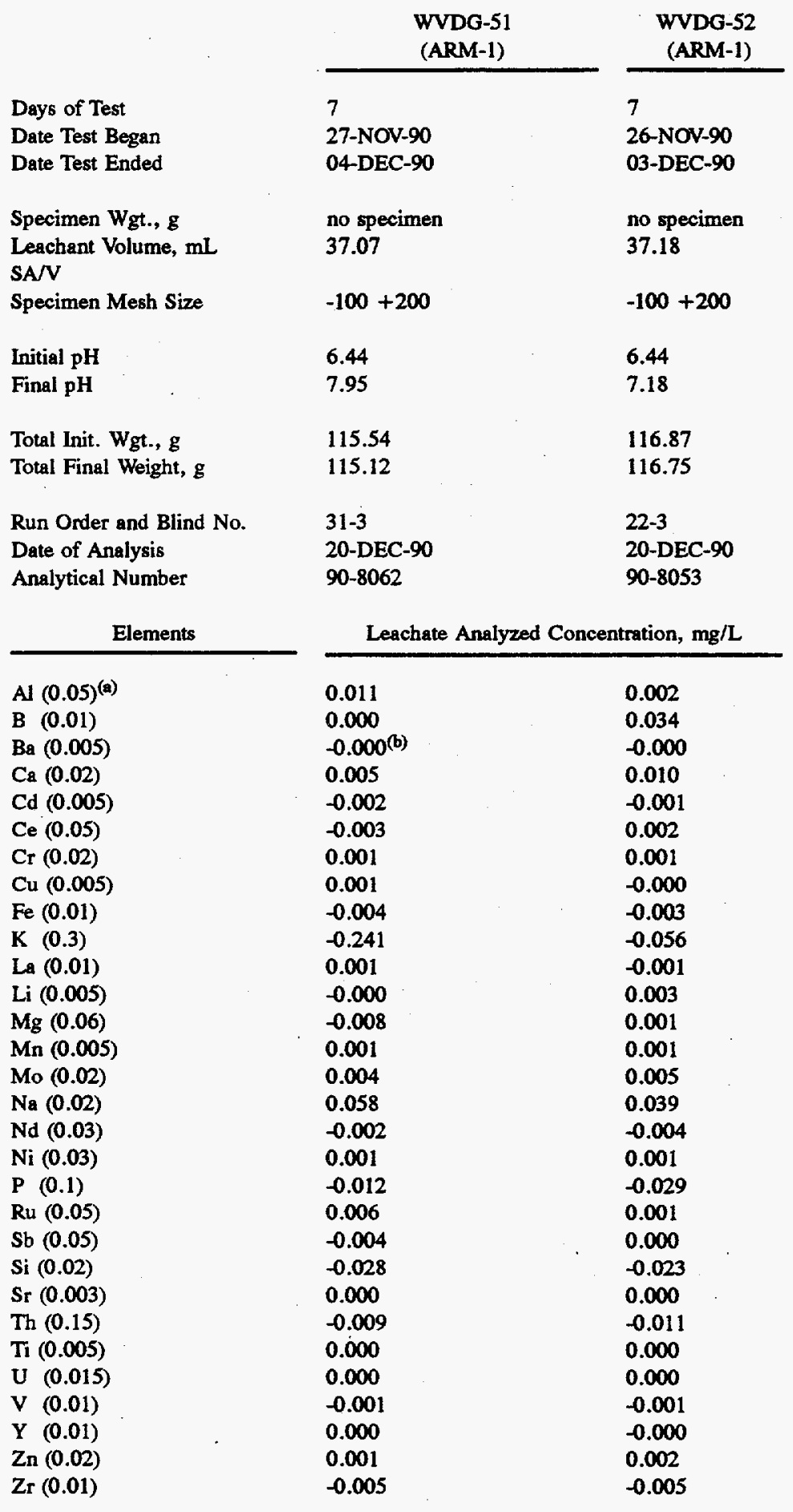

(a) Numbers in parentheses are instrument detection limits.

(b) Negative numbers are the result of random variation at low concentrations. 
Table A.4. Leachate IC Results for Ion Chromatagraph Results for all PCT Tests of West Valley Compositional Variability Series

\begin{tabular}{|c|c|c|c|c|c|c|c|c|c|}
\hline & WVDG-1 & WVDG-2 & WVDG-3 & WVDG-4 & WVDG-5 & WVDG-6 & WVDG-7 & WVDG-8 & WVDG-11R \\
\hline F, Series 1 & $<0.2$ & $<0.2^{*}$ & $<0.2^{*(a)}$ & $<0.2^{*}$ & $<0.2$ & $<0.2^{*}$ & $<0.2$ & $<0.2$ & $<0.2^{*}$ \\
\hline F, Series 2 . & $<0.2^{*}$ & $<0.2$ & $<0.2^{*}$ & $<0.2^{*}$ & $<0.2^{*}$ & $<0.2^{*}$ & $<0.2^{*}$ & $<0.2^{*}$ & $<0.2^{*}$ \\
\hline F, Series 3 & $<0.2^{*}$ & $<0.2^{*}$ & $<0.2^{*}$ & $<0.2^{*}$ & $<0.2 *$ & $<0.2^{*}$ & $<0.2^{*}$ & $<0.2^{*}$ & $0.2^{*}$ \\
\hline Cl, Series 1 & 0.2 & 0.2 & $<0.2$ & 0.2 & 0.2 & 0.2 & 0.2 & 0.2 & 0.2 \\
\hline $\mathrm{Cl}$, Series 2 & $<0.2$ & $<0.2$ & 0.2 & 0.3 & $<0.2$ & $<0.2$ & 0.2 & $<0.2$ & $<0.2$ \\
\hline Cl, Series 3 & $<0.2$ & $<0.2$ & 0.2 & $0.3^{*}$ & $0.2^{*}$ & $<0.2$ & $<0.2^{*}$ & $<0.2$ & $0.2^{*}$ \\
\hline $\mathrm{NO}_{2}$, Series 1 & $<0.4$ & $<0.4$ & $<0.4$ & $<0.4$ & $<0.4$ & $<0.4$ & $<0.4$ & $<0.4$ & $<0.4$ \\
\hline $\mathrm{NO}_{2}$, Series 2 & $<0.4$ & $<0.4$ & $<0.4$ & $<0.4$ & $<0.4$ & $<0.4$ & $<0.4$ & $<0.4$ & $<0.4$ \\
\hline $\mathrm{NO}_{2}$, Series 3 & $<0.4$ & $<0.4$ & $<0.4$ & $<0.4$ & $<0.4$ & $<0.4$ & $<0.4$ & $<0.4$ & $<0.4$ \\
\hline Br, Series 1 & $<0.2$ & $<0.2$ & $<0.2$ & $<0.2$ & $<0.2$ & $<0.2$ & $<0.2$ & $<0.2$ & $<0.2$ \\
\hline Br, Series 2 & $<0.2$ & $<0.2$ & $<0.2$ & $<0.2$ & $<0.2$ & $<0.2$ & $<0.2$ & $<0.2$ & $<0.2$ \\
\hline Br, Series 3 & $<0.2$ & $<0.2$ & $<0.2$ & $<0.2$ & $<0.2$ & $<0.2$ & $<0.2$ & $<0.2$ & $<0.2$ \\
\hline $\mathrm{NO}_{3}$, Series 1 & $<0.4$ & 0.4 & $<0.4$ & $<0.4$ & $<0.4$ & $<0.4$ & $<0.4$ & $<0.4$ & $<0,4$ \\
\hline $\mathrm{NO}_{3}$, Series 2 & 0.4 & $<0.4$ & 0.4 & 0.5 & $<0.4$ & 1.9 & $<0.4$ & $<0.4$ & $<0.4$ \\
\hline $\mathrm{NO}_{3}$, Series 3 & $<0.4$ & $<0.4$ & $<0.4$ & $<0.4$ & $<0.4$ & $<0.4$ & $<0.4$ & $<0.4$ & $<0.4$ \\
\hline $\mathrm{PO}_{4}$, Series 1 & 5.5 & 6.8 & 13.1 & 12.8 & 8.8 & 9.6 & 5.9 & 8.0 & 11.0 \\
\hline $\mathrm{PO}_{4}$, Series 2 & 5.4 & 7.4 & 13.1 & 13.5 & 8.8 & 9.4 & 6.4 & 8.8 & 10.0 \\
\hline $\mathrm{PO}_{4}$, Series 3 & 5.4 & 7.3 & 11.8 & 13.0 & 8.3 & 9.1 & 5.5 & 8.6 & 10.9 \\
\hline $\mathrm{SO}_{4}$. Series 1 & 1.2 & 1.2 & 2.0 & 1.6 & 1.3 & 1.3 & 1.2 & 1.2 & 1.4 \\
\hline $\mathrm{SO}_{4}$, Series 2 & 1.1 & 1.2 & 2.1 & 1.5 & 1.2 & 1.4 & 1.2 & 1.2 & 1.4 \\
\hline \multirow[t]{2}{*}{$\mathrm{SO}_{4}$, Series 3} & 1.2 & 1.3 & 1.9 & 1.5 & 1.3 & 1.4 & 1.2 & 1.2 & 1.5 \\
\hline & WVDG-12R & WVDG-13R & WVDG-14R & WVDG-15 & WVDG-16 & WVDG-17 & WVDG-18 & WVDG-19 & WVDG-20 \\
\hline$F$, Series 1 & $<0.2$ & $<0.2$ & $<0.2^{*}$ & $<0.2^{*}$ & $<0.2 *$ & $<0.2 *$ & $<0.2$ & $<0.2^{*}$ & $<0.2$ \\
\hline F, Series 2 & $<0.2^{*}$ & $<0.2^{*}$ & $<0.2^{*}$ & $<0.2^{*}$ & $<0.2$ & $<0.2 *$ & $<0.2^{*}$ & $<0.2^{*}$ & $<0.2^{*}$ \\
\hline F, Series 3 & $<0.2^{*}$ & $0.2^{*}$ & $<0.2^{*}$ & $<0.2^{*}$ & $0.2^{*}$ & $<0.2^{*}$ & $<0.2^{*}$ & $<0.2$ & $<0.2^{*}$ \\
\hline Cl, Series 1 & $<0.2$ & 0.2 & 0.2 & 0.3 & 0.2 & 0.2 & $<0.2$ & 0.2 & 0.2 \\
\hline $\mathrm{Cl}$, Series 2 & $<0.2$ & $<0.2$ & 0.3 & 0.2 & $<0.2$ & $<0.2$ & $<0.2$ & 0.2 & $<0.2$ \\
\hline $\mathrm{Cl}$, Series 3 & $<0.2^{*}$ & $<0.2$ & $0.9^{*}$ & $0.3^{*}$ & $<0.2^{*}$ & $0.3^{*}$ & $<0.2$ & $<0.2$ & $<0.2$ \\
\hline $\mathrm{NO}_{2}$, Series 1 & $<0.4$ & $<0.4$ & $<0.4$ & $<0.4$ & $<0.4$ & $<0.4$ & $<0.4$ & $<0.4$ & $<0.4$ \\
\hline $\mathrm{NO}_{2}$, Series 2 & $<0.4$ & $<0.4$ & $<0.4$ & $<0.4$ & $<0.4$ & $<0.4$ & $<0.4$ & $<0.4$ & $<0.4$ \\
\hline $\mathrm{NO}_{2}$, Series 3 & $<0.4$ & $<0.4$ & $<0.4$ & $<0.4$ & $<0.4$ & $<0.4$ & $<0.4$ & $<0.4$ & $<0.4$ \\
\hline $\mathrm{Br}$, Series 1 & $<0.2$ & $<0.2$ & $<0.2$ & $<0.2$ & $<0.2$ & $<0.75^{*}$ & $<0.2$ & $<0.2$ & $<0.2$ \\
\hline Br, Series 2 & $<0.2$ & $<0.2$ & $<0.2$ & $<0.2$ & $<0.2$ & $<0.2$ & $<0.2$ & $<0.2$ & $<0.2$ \\
\hline Br, Series 3 & $<0.2$ & $<0.2$ & $<0.2$ & $<0.2$ & $<0.2$ & $<0.2$ & $<0.2$ & $<0.2$ & $<0.2$ \\
\hline $\mathrm{NO}_{3}$, Series 1 & 0.4 & 0.4 & $<0.4$ & $<0.4$ & $<0.4$ & $1.8 *$ & $<0.4$ & 0.5 & $<0.4$ \\
\hline $\mathrm{NO}_{3}$, Series 2 & $<0.4$ & $<0.4$ & $<0.4$ & 0.7 & $<0.4$ & 0.5 & $<0.4$ & $<0.4$ & $<0.4$ \\
\hline $\mathrm{NO}_{3}$, Series 3 & 0.4 & $<0.4$ & $<0.4$ & $<0.4$ & $<0.4$ & $<0.4$ & $<0.4$ & $<0.4$ & $<0.4$ \\
\hline $\mathrm{PO}_{4}$, Series 1 & 11.7 & 11.0 & 13.0 & 8.4 & 7.1 & 8.7 & 6.9 & 5.7 & 4.0 \\
\hline $\mathrm{PO}_{4}$, Series 2 & 10.3 & 11.1 & 12.9 & 8.7 & 6.8 & 8.3 & 7.6 & 4.9 & 4.2 \\
\hline $\mathrm{PO}_{4}$, Series 3 & 9.9 & 11.4 & 13.3 & 7.9 & 7.3 & 8.6 & 7.0 & 4.9 & 4.6 \\
\hline $\mathrm{SO}_{4}$, Series 1 & 2.3 & 1.4 & 1.5 & 2.1 & 0.5 & 2.4 & 0.7 & 1.1 & 1.1 \\
\hline $\mathrm{SO}_{4}$, Series 2 & 2.6 & 1.4 & 1.5 & 2.1 & 0.5 & 2.3 & 0.7 & 1.0 & 1.2 \\
\hline $\mathrm{SO}_{4}$, Series 3 & 3.3 & 1.5 & 1.6 & 2.0 & 0.6 & 2.5 & 0.7 & 1.2 & 1.4 \\
\hline
\end{tabular}

(a) Asterisk indicates matrix interference. 
Table A.4. (contd)

\begin{tabular}{|c|c|c|c|c|c|c|c|c|c|}
\hline & WVDG-21 & WVDG-22 & WVDG-23 & WVDG-24 & WVDG-25 & WVDG-26 & WVDG-27 & WVDG-28 & WVDG-29 \\
\hline F, Series 1 & $<0.2$ & $<0.2$ & $<0.2^{*}$ & $<0.2^{*(a)}$ & $<0.2^{*}$ & $<0.2$ & $<0.2$ & $<0.2$ & $<0.2^{*}$ \\
\hline F, Series 2 & 0.20 & $<0.2^{*}$ & $<0.2^{*}$ & $<0.2 *$ & $<0.2^{*}$ & $<0.2^{*}$ & $<0.2^{*}$ & $<0.2^{*}$ & $<0.2^{*}$ \\
\hline F, Series 3 & $<0.2^{*}$ & $<0.2^{*}$ & $<0.2^{*}$ & $<0.2^{*}$ & $<0.2$ & $0.2^{*}$ & $<0.2^{*}$ & $0.2^{*}$ & $<0.2^{*}$ \\
\hline $\mathrm{Cl}$, Series 1 & 0.20 & 0.2 & 0.2 & 0.2 & 0.2 & $<0.2$ & 0.3 & 0.2 & 0.2 \\
\hline $\mathrm{Cl}$, Series 2 & $<0.2$ & $<0.2$ & 0.3 & $<0.2$ & 0.2 & 0.3 & 0.4 & $<0.2$ & $<0.2$ \\
\hline $\mathrm{Cl}$, Series 3 & $0.2^{*}$ & $<0.2^{*}$ & $<0.2^{*}$ & $<0.2^{*}$ & $<0.2$ & $<0.2^{*}$ & $0.3^{*}$ & $0.2^{*}$ & $0.3^{*}$ \\
\hline $\mathrm{NO}_{2}$, Series 1 & $<0.4$ & $<0.4$ & $<0.4$ & $<0.4$ & $<0.4$ & $<0.4$ & $<0.4$ & $<0.4$ & $<0.4$ \\
\hline $\mathrm{NO}_{2}$, Series 2 & $<0.4$ & $<0.4$ & $<0.4$ & $<0.4$ & $<0.4$ & $<0.4$ & $<0.4$ & $<0.4$ & $<0.4$ \\
\hline $\mathrm{NO}_{2}$, Series 3 & $<0.4$ & $<0.4$ & $<0.4$ & $<0.4$ & $<0.4$ & $<0.4$ & $<0.4$ & $<0.4$ & $<0.4$ \\
\hline Br, Series 1 & $<0.2$ & $<0.2$ & $<0.2$ & $<0.2$ & $<0.2$ & $<0.2$ & $<0.75^{*}$ & $<0.2$ & $<0.2$ \\
\hline Br, Series 2 & $<0.2$ & $<0.2$ & $<0.2$ & $<0.2$ & $<0.2$ & $<0.2$ & $<0.2$ & $<0.2$ & $<0.2$ \\
\hline Br, Series 3 & $<0.2$ & $<0.2$ & $<0.2$ & $<0.2$ & $<0.2$ & $<0.2$ & $<0.2$ & $<0.2$ & $<0.2$ \\
\hline $\mathrm{NO}_{3}$, Series 1 & $<0.4$ & $<0.4$ & $<0.4$ & $<0.4$ & 0.6 & $<0.4$ & $<0.4^{*}$ & $<0.4$ & $<0.4$ \\
\hline $\mathrm{NO}_{3}$, Series 2 & $<0.4$ & 1.0 & 0.5 & 0.5 & 0.6 & $<0.4$ & $<0.4$ & $<0.4$ & $<0.4$ \\
\hline $\mathrm{NO}_{3}$, Series 3 & $<0.4$ & $<0.4$ & $<0.4$ & 0.4 & $<0.4$ & $<0.4$ & $<0.4$ & $<0.4$ & $<0.4$ \\
\hline $\mathrm{PO}_{4}$, Series 1 & 11.60 & 3.0 & 7.3 & 6.0 & 7.0 & 6.7 & 8.8 & 3.9 & 17.5 \\
\hline $\mathrm{PO}_{4}$, Series 2 & 11.10 & 3.0 & 7.0 & 4.7 & 7.0 & 3.7 & 10.0 & 4.3 & 16.9 \\
\hline $\mathrm{PO}_{4}$, Series 3 & 10.10 & 3.0 & 6.6 & 4.5 & 7.4 & 3.6 & 8.6 & 4.6 & 18.7 \\
\hline $\mathrm{SO}_{4}$, Series 1 & 0.07 & 1.6 & 0.6 & 0.6 & 0.5 & 0.5 & 1.5 & 1.5 & 0.7 \\
\hline $\mathrm{SO}_{4}$, Series 2 & 0.70 & 1.6 & 0.6 & 0.6 & 0.5 & 0.6 & 1.7 & 1.6 & 0.7 \\
\hline \multirow[t]{2}{*}{$\mathrm{SO}_{4}$, Series 3} & 0.70 & 1.7 & 0.7 & 0.6 & 0.5 & 0.6 & 1.6 & 1.6 & 0.7 \\
\hline & WVDG-30 & WVDG-31B & WVDG-31C & WVDG-33 & WVDG-34 & WVDG-35 & WVDG-36 & WVDG-37 & WVDG-38 \\
\hline F, Series 1 & $<0.2^{*}$ & $<0.2$ & $<0.2^{*}$ & $<0.2$ & $<0.2$ & $<0.2^{*}$ & $<0.2$ & $<0.2^{*}$ & $<0.2^{*}$ \\
\hline F, Series 2 & $<0.2^{*}$ & $<0.2^{*}$ & $<0.2^{*}$ & $<0.2^{*}$ & $<0.2^{*}$ & $<0.2^{*}$ & $<0.2^{*}$ & $<0.2^{*}$ & $<0.2^{*}$ \\
\hline F, Series 3 & $<0.2^{*}$ & $<0.2^{*}$ & $<0.2^{*}$ & $0.2^{*}$ & $<0.2^{*}$ & $<0.2^{*}$ & $<0.2 *$ & $<0.2^{*}$ & $0.3 *$ \\
\hline $\mathrm{Cl}$, Series 1 & 0.2 & 0.2 & 0.2 & 0.2 & 0.4 & 0.2 & 0.3 & 0.2 & 0.2 \\
\hline Cl, Series 2 & $<0.2$ & $<0.2$ & $<0.2$ & $<0.2$ & 0.4 & 0.3 . & 0.3 & $<0.2$ & $<0.2$ \\
\hline $\mathrm{Cl}$, Series 3 & $0.2^{*}$ & 0.2 & $<0.2^{*}$ & $0.2^{*}$ & $0.4 *$ & $0.2^{*}$ & $<0.2^{*}$ & $0.2^{*}$ & $<0.2$ \\
\hline $\mathrm{NO}_{2}$, Series 1 & $<0.4$ & $<0.4$ & $<0.4$ & $<0.4$ & $<0.4$ & $<0.4$ & $<0.4$ & $<0.4$ & $<0.4$ \\
\hline $\mathrm{NO}_{2}$, Series 2 & $<0.4$ & $<0.4$ & $<0.4$ & $<0.4$ & $<0.4$ & $<0.4$ & $<0.4$ & $<0.4$ & $<0.4$ \\
\hline $\mathrm{NO}_{2}$, Series 3 & $<0.4$ & $<0.4$ & $<0.4$ & $<0.4$ & $<0.4$ & $<0.4$ & $<0.4$ & $<0.4$ & $<0.4$ \\
\hline $\mathrm{Br}$, Series 1 & $<0.2$ & $<0.2$ & $<0.2$ & $<0.2$ & $<0.2$ & $<0.2$ & $<0.2$ & $<0.2$ & $<0.2$ \\
\hline Br, Series 2 & $<0.2$ & $<0.2$ & $<0.2$ & $<0.2$ & $<0.2$ & $<0.2$ & $<0.2$ & $<0.2$ & $<0.2$ \\
\hline Br, Series 3 & $<0.2$ & $<0.2$ & $<0.2$ & $<0.2$ & $<0.2$ & $<0.2$ & $<0.2$ & $<0.2$ & $<0.2$ \\
\hline $\mathrm{NO}_{3}$, Series 1 & $<0.4$ & $<0.4$ & 0.5 & $<0.4$ & 0.4 & $<0.4$ & $<0.4$ & 0.4 & $<0.4$ \\
\hline $\mathrm{NO}_{3}$, Series 2 & $<0.4$ & 0.9 & $<0.4$ & 0.5 & $<0.4$ & 0.4 & $<0.4$ & $<0.4^{*}$ & $<0.4$ \\
\hline $\mathrm{NO}_{3}$, Series 3 & $<0.4$ & $<0.4$ & $<0.4$ & $<0.4$ & $<0.4$ & $<0.4$ & $<0.4$ & 0.5 & $<0.4$ \\
\hline $\mathrm{PO}_{4}$, Series 1 & 7.7 & 10.2 & 10.4 & 12.7 & 13.5 & 4.3 & 1.8 & 2.7 & 6.2 \\
\hline $\mathrm{PO}_{4}$, Series 2 & 6.4 & 26.6 & 10.6 & 14.2 & 11.8 & 4.4 & 2.0 & 2.7 & 2.3 \\
\hline $\mathrm{PO}_{4}$, Series 3 & 6.8 & 11.1 & 9.9 & 13.3 & 11.4 & 4.3 & 2.0 & 2.6 & 1.8 \\
\hline $\mathrm{SO}_{4}$, Series 1 & 1.1 & 1.3 & 1.7 & 0.9 & 3.3 & 0.9 & 1.7 & 2.3 & 1.7 \\
\hline $\mathrm{SO}_{4}$, Series 2 & 1.6 & $<0.4$ & 1.4 & 1.0 & 3.0 & 1.0 & 1.8 & 2.3 & 1.8 \\
\hline $\mathrm{SO}_{4}$, Series 3 & 1.1 & 1.4 & 1.3 & 1.0 & 3.0 & 1.0 & 1.8 & 2.3 & 1.8 \\
\hline
\end{tabular}

(a) Asterisk indicates matrix interference. 
Table A.4. (contd)

\begin{tabular}{|c|c|c|c|c|c|c|c|c|c|}
\hline & WVDG-39 & WVDG-40 & WVDG-41 & WVDG -42 & WVDG-43 & WVDG-44 & WVDG-45 & WVDG-46 & WVDG-47 \\
\hline F, Series 1 & 0.5 & $<0.2^{*(a)}$ & $<0.2^{*}$ & $<0.2$ & $<0.2^{*}$ & $<0.2^{*}$ & $<0.2^{*}$ & $<0.2^{*}$ & $<0.2$ \\
\hline F, Series 2 & $<0.2^{*}$ & $<0.2^{*}$ & $<0.4^{*}$ & $<0.2^{*}$ & $<0.2^{*}$ & $<0.2^{*}$ & $<0.2^{*}$ & $<0.2^{*}$ & $<0.2^{*}$ \\
\hline F, Series 3 & $<0.2$ & 0.2 & $<0.2^{*}$ & $<0.2^{*}$ & $<0.2^{*}$ & $0.2 *$ & not & $0.2 *$ & $<0.2^{*}$ \\
\hline $\mathrm{Cl}$, Series 1 & 0.2 & 0.3 & 0.9 & 0.3 & 0.2 & $<0.2^{*}$ & 0.2 & 0.4 & 0.2 \\
\hline $\mathrm{Cl}$, Series 2 & 0.4 & 0.3 & $<0.2$ & 0.3 & $<0.2$ & 0.4 & 0.2 & 0.4 & $<0.2$ \\
\hline Cl, Series 3 & 0.3 & 0.2 & $<0.2$ & $0.3^{*}$ & $<0.2^{*}$ & $0.3 *$ & analyzed & $0.4^{*}$ & $<0.2^{*}$ \\
\hline $\mathrm{NO}_{2}$, Series 1 & $<0.4$ & $<0.4$ & $<0.4$ & $<0.4$ & $<0.4$ & $<0.4$ & $<0.4$ & $<0.4$ & $<0.4$ \\
\hline $\mathrm{NO}_{2}$, Series 2 & $<0.4$ & $<0.4$ & $<0.4$ & $<0.4$ & $<0.4$ & $<0.4$ & $<0.4$ & $<0.4$ & $<0.4$ \\
\hline $\mathrm{NO}_{2}$, Series 3 & $<0.4$ & $<0.4$ & $<0.4$ & $<0.4$ & $<0.4$ & $<0.4$ & & $<0.4$ & $<0.4$ \\
\hline Br, Series 1 & $<0.2$ & $<0.2$ & $<0.2$ & $<0.2$ & $<0.2$ & $<0.2$ & $<0.2$ & $<0.2$ & $<0.75^{*}$ \\
\hline Br, Series 2 & $<0.2$ & $<0.2$ & $<0.2$ & $<0.2$ & $<0.2$ & $<0.2$ & $<0.2$ & $<0.2$ & $<0.2$ \\
\hline Br, Series 3 & $<0.2$ & $<0.2$ & $<0.2$ & $<0.2$ & $<0.2$ & $<0.2$ & & $<0.2$ & $<0.2$ \\
\hline $\mathrm{NO}_{3}$, Series 1 & $<0.4$ & $<0.4$ & 1.3 & $<0.4$ & $<0.4$ & $<0.4$ & 0.4 & $<0.4$ & 0.4 \\
\hline $\mathrm{NO}_{3}$, Series 2 & 0.4 & $<0.4$ & $<0.4$ & $<0.4$ & $<0.4$ & $<0.4$ & $<0.4$ & $<0.4$ & 0.5 \\
\hline $\mathrm{NO}_{3}$, Series 3 & 0.6 & $<0.4$ & $<0.40 .5$ & $<0.4$ & $<0.4$ & & $<0.4$ & $<0.4$ & $\cdot$ \\
\hline $\mathrm{PO}_{4}$, Series 1 & 19.9 & 3.4 & 31.6 & 33.4 & 5.9 & 2.8 & 28.3 & 2.8 & 14.6 \\
\hline $\mathrm{PO}_{4}$, Series 2 & 20.0 & 3.7 & 29.5 & 31.6 & 5.1 & 2.8 & 26.6 & 3.1 & 14.2 \\
\hline $\mathrm{PO}_{4}$, Series 3 & 21.8 & 4.1 & 29.5 & 32.1 & 4.4 & 2.7 & & 2.9 & 14.4 \\
\hline $\mathrm{SO}_{4}$, Series 1 & 0.6 & 0.8 & 0.7 & 3.6 & 0.4 & 0.9 & 0.8 & 0.6 & 0.5 \\
\hline $\mathrm{SO}_{4}$, Series 2 & 0.6 & 0.8 & 0.7 & 3.6 & 1.2 & 0.7 & 0.9 & 0.8 & 0.5 \\
\hline \multirow[t]{2}{*}{$\mathrm{SO}_{4}$, Series 3} & 0.5 & 0.9 & 0.6 & 3.7 & 0.4 & 0.7 & & 0.6 & $<0.6$ \\
\hline & WVDG-48 & $\begin{array}{l}\text { WVDG-49 } \\
\text { (ARM-1) }\end{array}$ & $\begin{array}{l}\text { WVDG-50 } \\
\text { (ARM-1) }\end{array}$ & $\begin{array}{l}\text { WVDG-51 } \\
\text { (Blank) }\end{array}$ & $\begin{array}{l}\text { WVDG-52 } \\
\text { (Blank }\end{array}$ & & & & \\
\hline F, Series 1 & $<0.2$ & $<0.2^{*}$ & $<0.2$ & 0.2 & $<0.2$ & & & & \\
\hline F, Series 2 & $<0.2^{*}$ & $<0.2^{*}$ & $<0.2$ & 0.2 & $<0.2^{*}$ & & & & \\
\hline F, Series 3 & $0.2^{*}$ & $0.2^{*}$ & $<0.2^{*}$ & $<0.2$ & 0.2 & & & . & \\
\hline Cl, Series 1 & 0.2 & 0.3 & 0.3 & $<0.2$ & $<0.2$ & & & & \\
\hline Cl, Series 2 & $<0.2$ & 0.3 & 0.3 & $<0.2$ & $<0.2$ & & & & \\
\hline Cl, Series 3 & $<0.2^{*}$ & $0.3^{*}$ & $<0.2^{*}$ & $<0.2$ & $<0.2$ & & & & \\
\hline $\mathrm{NO}_{2}$, Series 1 & $<0.4$ & $<0.4$ & $<0.4$ & $<0.4$ & $<0.4$ & & & & \\
\hline $\mathrm{NO}_{2}$, Series 2 & $<0.4$ & $<0.4$ & $<0.4$ & $<0.4$ & $<0.4$ & & & & \\
\hline $\mathrm{NO}_{2}$, Series 3 & $<0.4$ & $<0.4$ & $<0.4$ & $<0.4$ & $<0.4$ & & & & \\
\hline $\mathrm{Br}$, Series 1 & $<0.2$ & $<0.2$ & $<0.2$ & $<0.2$ & $<0.5^{*}$ & & & & \\
\hline Br, Series 2 & $<0.2$ & $<0.2$ & $<0.2$ & $<0.2$ & $<0.2$ & & & & \\
\hline $\mathrm{Br}$, Series 3 & $<0.2$ & $<0.2$ & $<0.2$ & $<0.2$ & $<0.2$ & & & & \\
\hline $\mathrm{NO}_{3}$, Series 1 & $<0.4$ & 0.5 & $<0.4$ & $<0.4$ & $<0.4^{*}$ & & & & \\
\hline $\mathrm{NO}_{3}$, Series 2 & $<0.4$ & $<0.4$ & $<0.4$ & $<0.4$ & $<0.4$ & & & & \\
\hline $\mathrm{NO}_{3}$, Series 3 & $<0.4$ & $<0.4$ & $<0.4$ & $<0.4$ & $<0.4$ & & & & . \\
\hline $\mathrm{PO}_{4}$, Series 1 & 6.7 & 2.7 & 2.3 & $<0.4$ & $<0.4$ & & & & \\
\hline $\mathrm{PO}_{4}$, Series 2 & 6.5 & 2.5 & 2.5 & $<0.4$ & $<0.4$ & & & & \\
\hline $\mathrm{PO}_{4}$, Series 3 & 6.1 & 2.3 & 2.3 & $<0.4$ & $<0.4$ & & & & \\
\hline $\mathrm{SO}_{4}$, Series 1 & 1.2 & $<0.4$ & $<0.4$ & $<0.4$ & $<0.4$ & & & & \\
\hline $\mathrm{SO}_{4}$, Series 2 & 1.2 & $<0.4$ & $<0.4$ & $<0.4$ & $<0.4$ & & & & \\
\hline $\mathrm{SO}_{4}$, Series 3 & 1.2 & $<0.4$ & $<0.4$ & $<0.4$ & $<0.4$ & & & & \\
\hline
\end{tabular}

(a) Asterisk indicates matrix interference. 


\section{Distribution}

No. of

Copies

Offsite

12 DOE/Office of Scientific and Technical Information

Carol Jantzen, 773A

P.O. Box 616

Westinghouse Savannah River Company

Aiken, SC 29801

Alice Drobot

West Valley Nuclear Services Company

P.O. Box 191

West Valley, NY 14171-0191

Ian Pegg

Catholic University of America

Vitreous State Laboratory

620 Michigan Avenue

Washington, D.C. 20064
No. of

Copies

Onsite

\section{DOE Richland Operations Office}

S. T. Burnum, S7-53

17 Pacific Northwest Laboratory

J. W. Johnston, K5-12

S. C. Marschman, P7-18

K. M. Olson (5), P7-14

G. F. Piepel, K5-12

M. J. Schweiger, P8-37

G. L. Smith, P7-14

G. K. Whiting, P8-44

Publishing Coordination

Technical Report Files (5) 